

\section{Tephra Layers of Blind Spring Valley and Related Upper Pliocene and Pleistocene Tephra Layers, California, Nevada, and Utah: Isotopic Ages, Correlation, and Magnetostratigraphy}

By Andrei M. Sarna-Wojcicki, Marith C. Reheis, Malcolm S. Pringle, Robert J. Fleck, Doug Burbank, Charles E. Meyer, Janet L. Slate, Elmira Wan, James R. Budahn, Bennie Troxel, and James P. Walker

Identification, chemical correlation, and isotopic dating of the widespread tephra layers of Blind Spring Valley allow correlation of associated sediments and tephra layers among numerous localities in the southwestern conterminous United States and provide a synoptic view of this large region during a short interval of late Cenozoic time.

Professional Paper 1701 


\section{U.S. Department of the Interior \\ Gale A. Norton, Secretary}

\section{U.S. Geological Survey Charles G. Groat, Director}

Any use of trade, product, or firm names in this publication is for descriptive purposes

only and does not imply endorsement of the U.S. Government.

United States Government Printing Office: 2005

For additional copies please contact:

\section{USGS Information Services}

Box 25286,

Denver, CO 80225

This report and any updates to it are available at:

http://pubs.usgs.gov/pp/pp1701/

Additional USGS publications can be found at:

http://geology.usgs.gov/products.html

For more information about the USGS and its products:

Telephone: 1-888-ASK-USGS (1-888-275-8747)

World Wide Web: http://www.usgs.gov/

Text edited by Peter H. Stauffer

Production and design by Sara Boore

Manuscript approved for publication, August 23, 2004

Cataloging-in-publication data are on file with the Library of Congress (URL http://

www.loc.gov/). 


\section{Contents}

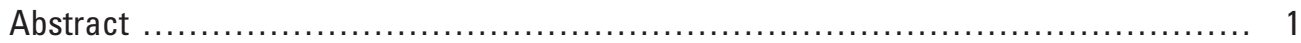

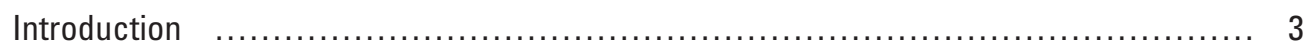

Tephra layers of Blind Spring Valley at the Cowan Pumice Mine $\ldots \ldots \ldots \ldots \ldots \ldots \ldots .4$

Tephra layers from other source areas in the western United States $\quad \ldots \ldots \ldots \ldots \ldots \ldots$

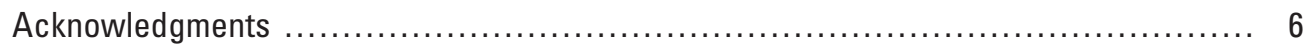

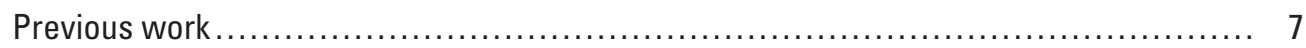

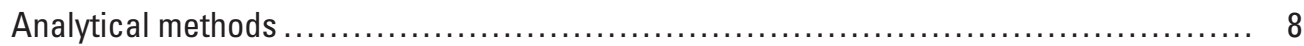

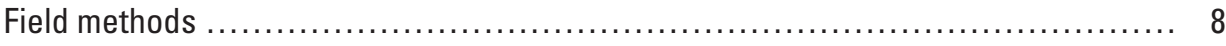

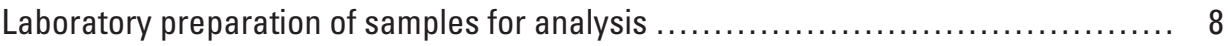

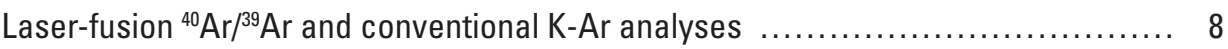

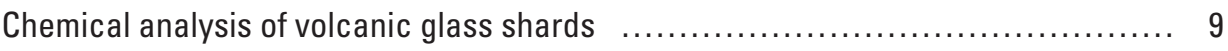

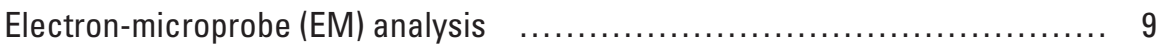

Energy-dispersive X-ray fluorescence (EDXRF) analysis $\ldots \ldots \ldots \ldots \ldots \ldots \ldots . \ldots$

Instrumental neutron activation (INA) analysis ........................... 9

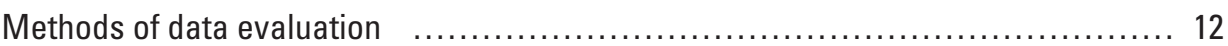

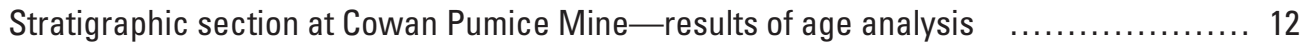

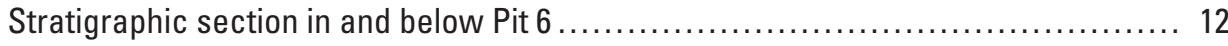

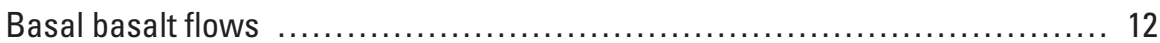

Basal arkosic mudflows and the tuff of Benton Hot Springs $\ldots \ldots \ldots \ldots \ldots \ldots \ldots \ldots \ldots \ldots$

Tuffs of Blind Spring Valley ........................................... 15

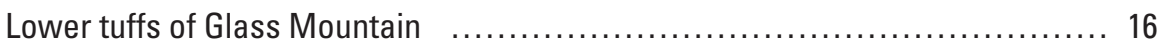

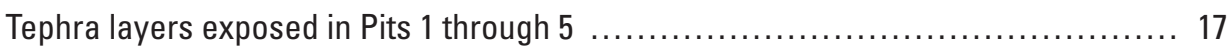

The Bishop ash ..................................................... 17

Tuffs of Blind Spring Valley ............................................ 17

Isotopic ages of the upper Glass Mountain tephra layers at Chalk Cliffs, at the south end of

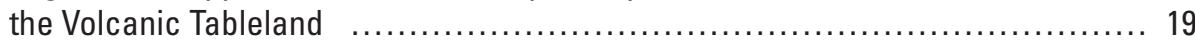

Interpretation of the isotopic ages at the Cowan Pumice Mine ......................... 21

Correlation of the tuffs of Blind Spring Valley to sites in the region $\ldots \ldots \ldots \ldots \ldots \ldots \ldots \ldots \ldots 28$

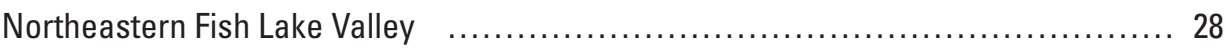

Willow Wash section ..................................................... 30

Yellowjacket Canyon, Chalfant Valley, east-central California $\quad \ldots \ldots \ldots \ldots \ldots \ldots \ldots \ldots . \ldots \ldots \ldots$

Waucoba lake beds, near Big Pine, Owens Valley, California $\quad . . \ldots \ldots \ldots \ldots \ldots \ldots \ldots . \ldots . \ldots 33$

Correlation of the Tuffs of Blind Spring Valley and related tephra layers to distal sites in the

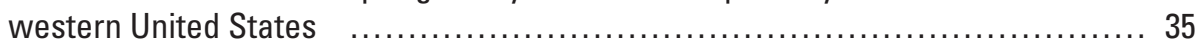

Confidence Hills, Death Valley, southeastern California ......................... 35

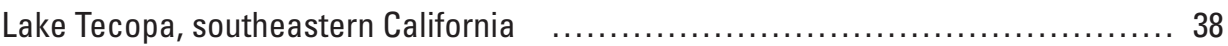

Manix Basin, central Mojave Desert, southern California ......................... 39

Peninsular Ranges, California ............................................ 41

Ventura Basin, southwestern coastal California............................. 41

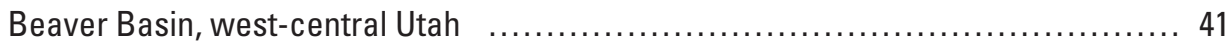

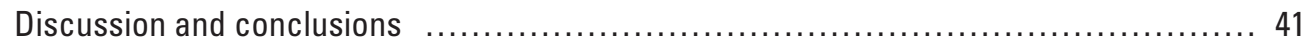

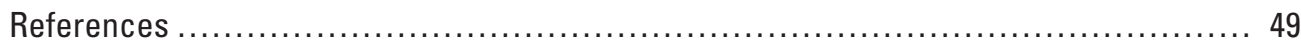




\section{Appendixes}

Appendix 1. Analytical data for laser-fusion ${ }^{40} \mathrm{Ar} /{ }^{39} \mathrm{Ar}$ age determinations of tephra layers..... $\quad 5$

Appendix 2. Analytical data for conventional K-Ar analysis of obsidian clasts from the lower tephra layers of Glass Mountain at the Cowan Pumice Mine, Blind Spring Valley, Calif.

Apendix 3. Analytical data for laser-fusion ${ }^{40} \mathrm{Ar} /{ }^{39} \mathrm{Ar}$ analysis of samples that were contaminated with detrital material

\section{Figures}

1. Map showing sample localities of tuffs of Blind Spring Valley and related tephra layers, known distribution of tuffs of Blind Spring Valley, and locations of Glass Mountain and the Long Valley Caldera

2. Generalized geologic map of the vicinity of Long Valley Caldera, Glass Mountain, Cowan Pumice Mine, and the south end of the Volcanic Tableland

3. Map showing locations of pumice pits at Cowan Pumice Mine and cross sections $A-A^{\prime}$ and $B-B^{\prime}$

4. Cross sections $A-A^{\prime}$ and $B-B^{\prime}$ in area of Cowan Pumice Mine, Blind Spring Valley, showing locations of samples in Pits 1-6 and ${ }^{40} \mathrm{Ar} /{ }^{39} \mathrm{Ar}$ ages

5. Photograph showing exposure of tuffs of Blind Spring Valley and lower tuffs of Glass Mountain in Pit 6, Cowan Pumice Mine ................................ 13

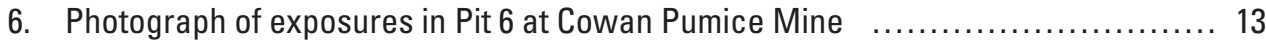

7. Stratigraphic section of exposure in Pit 6, Cowan Pumice Mine ................... 14

8. Photograph showing upper part of section in Pit 6, Cowan Pumice Mine ........... 16

9. Photograph showing two thick, coarse pumice-fall tuffs of Blind Spring Valley at south wall of Pit 5, Cowan Pumice Mine ................................... 17

10. Stratigraphic section of tuffs of Blind Spring Valley at Pit 5, Cowan Pumice Mine ... 18

11. Photograph of tuff of Blind Spring Valley in Pit 2, Cowan Pumice Mine ............. 19

12. Composite stratigraphic section at Chalk Cliffs, south end of Volcanic Tableland ...... 25

13. Stratigraphy of section exposed near Emigrant Pass, northeast Fish Lake Valley, Nevada

14. Photograph showing tuff of Benton Hot Springs, near base of Rimrock section at Willow Wash

15. Stratigraphy of sections at Willow Wash, south of Fish Lake Valley, California-Nevada 31

16. Photograph of Bishop Tuff near head of Yellowjacket Canyon ..................... 32

17. Location map and stratigraphic section of Waucoba Lake Beds near Big Pine, California

18. Magnetostratigraphy, stratigraphy, and tephrostratigraphy of the Confidence Hills section, Death Valley National Park, California .................................... 36

19. Correlation diagram of the tuffs of Blind Spring Valley and related tephra units ...... 39

20. Photograph showing exposure of tuff of Blind Spring Valley in Beaver Basin, Utah ... 44

21. Correlation diagram showing magnetostratigraphy and chronology of the tuffs of Blind Spring Valley and related tephra units at selected sites in the southwestern United States.

22. Diagram showing chronology of tuffs of Blind Spring Valley and related tephra layers compared to chronology of near-source Glass Mountain rhyolites 


\section{Tables}

1. Chemical composition of volcanic glass shards, determined by electron-microprobe analysis, and ages of tephra layers sampled from quarry pits at the Cowan Pumice

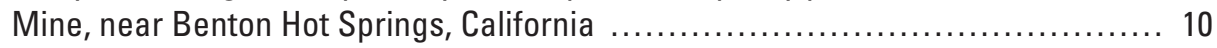

2. Electron-microprobe analysis of glass of the Bishop Tuff and Bishop airfall pumice, compared with the younger set of tephra layers of Glass Mountain ................ 20

3. Chemical composition of volcanic glass shards, determined by electron-microprobe analysis, from middle Pleistocene and upper Pliocene tephra layers of northeastern Fish Lake Valley, Calif.-Nev. (Emigrant Pass area and vicinity)

4. Electron-microprobe analyses of volcanic glass shards from middle Pleistocene and upper Pliocene tephra layers of the Willow Wash area, south of Fish Lake

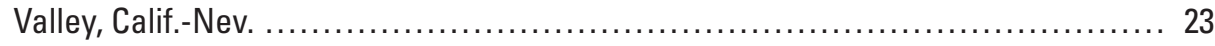

5. Energy-dispersive $X$-ray fluorescence analysis of volcanic glass from tephra layers ... 26

6. Results of electron-microprobe analysis of glass from tephra layers in exposures of the Waucoba lake beds, east side of Owens Valley

7. Glass chemical composition of tephra layers exposed in deformed alluvial and lacustrine sediments of the Confidence Hills, southern Death Valley, Calif.....

8. Glass chemical composition of tephra layers from several sites in southern and southwestern California and in Beaver Basin, Utah....

9. Glass chemical composition of the Huckleberry Ridge ash bed from sites in the western and central United States, as determined by electron-microprobe analyses ... 42

10. Instrumental neutron-activation analysis of selected samples of the tuff of Blind Spring Valley, from the Cowan Pumice Mine (TTC-), and correlative or chemically related tephra layers erupted from the Glass mountain volcanic source area ..... 


\section{Tephra Layers of Blind Spring Valley and Related Upper Pliocene and Pleistocene Tephra Layers, California, Nevada, and Utah: Isotopic Ages, Correlation, and Magnetostratigraphy}

By Andrei M. Sarna-Wojcicki ${ }^{1}$, Marith C. Reheis ${ }^{2}$, Malcolm S. Pringle ${ }^{3}$, Robert J. Fleck', Doug Burbank ${ }^{4}$, Charles E. Meyer ${ }^{1}$, Janet L. Slate ${ }^{2}$, Elmira Wan ${ }^{5}$, James R. Budahn², Bennie Troxel ${ }^{6}$, and James P. Walker ${ }^{1}$

\begin{tabular}{|c|c|c|c|}
\hline \multicolumn{4}{|c|}{$\begin{array}{l}\text { Numerical ages have been determined for a stratigraphic sequence of silicic tephra layers } \\
\text { exposed at the Cowan Pumice Mine in Blind Spring Valley, near Benton Hot Springs, east-cen- } \\
\text { tral California, as well as at Chalk Cliffs, north of Bishop, Calif. The tephra layers at these sites } \\
\text { were deposited after eruptions from nearby sources, most of them from near Glass Mountain, } \\
\text { and some from unknown sources. The ages were determined primarily by the laser-fusion } \\
{ }^{40} \mathrm{Ar} /{ }^{39} \mathrm{Ar} \text { method, mostly on sanidine feldspar; two were determined by conventional K-Ar } \\
\text { analysis on obsidian clasts. These tephra layers, all underlying the Bishop ash bed and listed in } \\
\text { order of concordant age and stratigraphic position, are: }\end{array}$} \\
\hline Tephra Unit & Method & Material & Age \\
\hline Bishop Tuff (air-fall pumice) & $\mathrm{Ar} / \mathrm{Ar}$ & sanidine & $0.759 \pm 0.002 \mathrm{Ma}^{*}$ \\
\hline Upper tuffs of Glass Mountain & $\mathrm{Ar} / \mathrm{Ar}$ & sanidine & $0.87 \pm 0.02 \mathrm{Ma}$ \\
\hline Upper tuffs of Glass Mountain & $\mathrm{Ar} / \mathrm{Ar}$ & sanidine & $1.13 \pm 0.19 \mathrm{Ma}$ \\
\hline \multirow[t]{2}{*}{ Lower tuffs of Glass Mountain } & $\mathrm{K}-\mathrm{Ar}$ & obsidian & $1.86 \pm 0.09 \mathrm{Ma}$ (avg of 2 dates) \\
\hline & $\mathrm{Ar} / \mathrm{Ar}$ & sanidine & $1.92 \pm 0.02 \mathrm{Ma}$ (avg of 2 dates) \\
\hline \multirow[t]{2}{*}{ Tuffs of Blind Spring Valley } & $\mathrm{Ar} / \mathrm{Ar}$ & sanidine & $2.135 \pm 0.02$ to \\
\hline & & sanidine & $2.219 \pm 0.006 \mathrm{Ma}(10$ dates $)$ \\
\hline Tuffs of Benton Hot Springs & $\mathrm{Ar} / \mathrm{Ar}$ & plagioclase & $2.81 \pm 0.02 \mathrm{Ma}$ \\
\hline
\end{tabular}

*Date published previously

The above tephra layers were also petrographically examined and the volcanic glass shards of the layers were chemically analyzed using the electron microprobe and, for some samples, instrumental neutron activation analysis and X-ray fluorescence. The same types of chemical and petrographic analyses were conducted on stratigraphic sequences of tephra layers of

${ }^{1}$ U.S. Geological Survey, 345 Middlefield Rd., Menlo Park, CA 94025

${ }^{2}$ U.S. Geological Survey, Denver Federal Survey, Denver, CO 80225.

${ }^{3}$ Scottish Universities Research and Reactor Center, Glasgow, Scotland

${ }^{4}$ Department of Geological Science, University of California, Santa Barbara, CA 93106

5945 Madison Street, Albany, CA 94706

${ }^{6}$ Department of Geology, University of California, Davis, CA 95616 
suspected upper Pliocene and Pleistocene age in several past and present depositional basins within the region outside of Blind Spring Valley. Chemical characterization, combined with additional dates and with magnetostratigraphy of thick sections at two of the distal sites, allow correlation of the tephra layers at the Cowan Pumice Mine with layers present at the distal sites and provide age constraints for other intercalated tephra layers and sediments for which age data were previously lacking. The identification at several sections of the widespread Huckleberry Ridge ash bed, derived from the Yellowstone eruptive source area in Wyoming, as well as a new ${ }^{40} \mathrm{Ar} /{ }^{39} \mathrm{Ar}$ age on this ash bed from a proximal locality, provide additional age constraints to several of the distal sections. The dated or temporally bracketed distal units, in order of concordant age and stratigraphic position, are:

\begin{tabular}{|c|c|c|c|}
\hline Tephra Unit & Method & Material & Age \\
\hline $\begin{array}{l}\text { Tephra layers of Glass } \\
\text { Mountain (undiff.) }\end{array}$ & P-mag.*; correlation & N/A & $<1.78 \mathrm{Ma}$ \\
\hline $\begin{array}{l}\text { Tephra layers of Glass } \\
\text { Mountain (lower) }\end{array}$ & P-mag.*; correlation & N/A & $>1.78,<1.96 \mathrm{Ma}$ \\
\hline $\begin{array}{l}\text { Tephra layers of Emigrant } \\
\text { Pass }\end{array}$ & P-mag.*; correlation & N/A & $>1.96,<2.06 \mathrm{Ma}$ \\
\hline $\begin{array}{l}\text { Tephra layer of Confidence } \\
\text { Hills }\end{array}$ & Correlation, p-mag.* & N/A & $>1.96,<2.06 \mathrm{Ma}$ \\
\hline Huckleberry Ridge ash bed & Ar/Ar; correlation & sanidine & $2.063 \pm 0.007 \mathrm{Ma}$ \\
\hline $\begin{array}{l}\text { Tephra layers of Blind } \\
\text { Spring Valley }\end{array}$ & Correlation & N/A & 2.135 to $2.219 \mathrm{Ma}$ \\
\hline $\begin{array}{l}\text { Tephra layers of the } \\
\text { Badlands (upper) }\end{array}$ & Correlation; p-mag.* & N/A & $>2.22,<2.57 \mathrm{Ma}$ \\
\hline $\begin{array}{l}\text { Tephra layers of the } \\
\text { Badlands (lower) }\end{array}$ & P-mag.*; correlation & N/A & $>2.57,<2.89 \mathrm{Ma}$ \\
\hline $\begin{array}{l}\text { Tephra layers of Benton Hot } \\
\text { Springs }\end{array}$ & Ar/Ar; correlation & plagioclase & $2.89 \pm 0.03 \mathrm{Ma}$ \\
\hline
\end{tabular}

*Magnetostratigraphic polarity determination

At the Cowan Pumice Mine, only a partial section of the eruptive record is preserved, but the best materials for laser-fusion ${ }^{40} \mathrm{Ar} /{ }^{39} \mathrm{Ar}$ and other isotopic dating methods were obtained. In the more distal Willow Wash and Confidence Hills sections, both persistent depositional basins for most of late Pliocene time, more complete sections of upper Pliocene tephra layers were preserved. In the region of Glass Mountain, the tephra layers that make up each of the mapped and dated pyroclastic units are multiple and complex, but a progressive simplification of the stratigraphy away from the source area was observed for more distal sites in southern and southwestern California and in Utah. This progressive simplification is attributed to both variable explosiveness and magnitude of individual tephra eruptions, as well as to variable dispersal of the tephra by winds during an eruptive episode. Lake beds present at several localities in the western Great Basin (Fish Lake Valley, Nev.; the Waucoba Road area near Big Pine, Calif.; and Confidence Hills, Death Valley, Calif.) are dated between $\sim 2.15$ and $\sim 2.04 \mathrm{Ma}$ and indicate that wetter or colder conditions than present existed at these sites. Age and correlation data presented here provide a chronostratigraphic framework for studies of late Neogene stratigraphy, tectonics, and environmental change in the southwestern United States.

Two Reunion magnetic events are bracketed between $\sim 2.18$ and $\sim 2.17$ Ma for the older (Reunion I) and between $\sim 2.16$ and $\sim 2.14$ Ma for the younger (Reunion II). A third, older excursion associated with these two is at $2.22 \mathrm{Ma}$, but it does not reach reversed magnetization. 


\section{Introduction}

Tephrochronology consists of three main activities: (1) a search for relatively pure tephra layers in stratigraphic sections, followed by mapping of their areal distributions and determination of their stratigraphic relationships in the field, (2) the chemical and petrographic characterization of the layers, and (3) the determination of their ages by isotopic or other methods. The best materials for many types of isotopic analysis $\left({ }^{40} \mathrm{Ar} /{ }^{39} \mathrm{Ar}, \mathrm{K}-\mathrm{Ar}\right.$, fission-track) are found at or near the eruptive source areascoarse air-fall pumice layers containing large mineral grains and stratigraphically associated lava flows. However, complete stratigraphic sections are rarely preserved near the source areas because of rapid volcanic/tectonic deformation and accompanying stuctural complications, erosion, or burial by clastic sediments and volcanic flows. Hence, part of the eruptive record is commonly missing, while the remainder may be difficult to interpret or concealed. Long-lived sedimentary basins are sites where records of the larger widespread eruptions from multiple sources are preserved and their stratigraphic relations can be determined. Such basins are usually at some distance from volcanic centers. Tephra layers preserved in such basins are commonly thinner, finer-grained, and impure owing to reworking, and thus not ideal for isotopic dating. The grain-size characterstics of such tephra and associated sediments, however, are often suitable for paleomagnetic studies, and tephra layers in these basins can be characterized by their petrography and chemical composition.

The optimal strategy for developing regional chronostratigraphic frameworks using tephrochronology, therefore, is to use a combination of near-source airfall deposits and exposed sections or cores in downwind long-lived sedimentary basins. Employing this approach, this study uses tephrochronology to correlate and date a suite of upper Pliocene and Pleistocene tephra layers in California and Nevada. The tephra that formed these layers was erupted mainly from a long-lived volcanic source in east-central California, in the vicinity of Glass Mountain, as well as from one or more unknown eruptive centers in this region. Our strategy in this study was to (1) obtain isotopic ages on proximal tephra layers using primarily the laserfusion ${ }^{40} \mathrm{Ar} /{ }^{39} \mathrm{Ar}$ method, (2) correlate the tephra units from the proximal localities to distal locations in long-lived depositional basins by chemical and petrographic criteria and, where possible, to determine the magnetostratigraphy at the latter sites, and (3) integrate the isotopic-age, correlation, stratigraphic, and magnetostratigraphic data components to arrive at a regional chronostratigraphic framework for the upper Pliocene and Pleistocene sequences within the region that contains these layers.

Although this strategy now seems straightforward, we arrived at it piecemeal, by several different earlier studies conducted by different individuals over a period of about 25 years. This report encompasses results of several of these studies, mostly unpublished, carried on independently in several different depositional basins or within smaller areas of the study region.

We report here on the informally named tephra layers of Blind Spring Valley, at the Cowan Pumice Mine in Blind Spring Valley, about $17 \mathrm{~km}$ east of Glass Mountain, and related tephra layers that underlie and overlie the tephra layers of Blind Spring Valley. These tephra layers are correlated by means of their chemical composition and petrographic characteristics to other sites in the region within a few tens of kilometers from Glass Mountain and to more distant sites in California, Nevada, and Utah.

The region around Glass Mountain and Long Valley (fig. 1), in east-central California, has been a center of longlived silicic volcanism in late Cenozoic time. Repeated volcanic eruptions from this center, beginning perhaps as early as

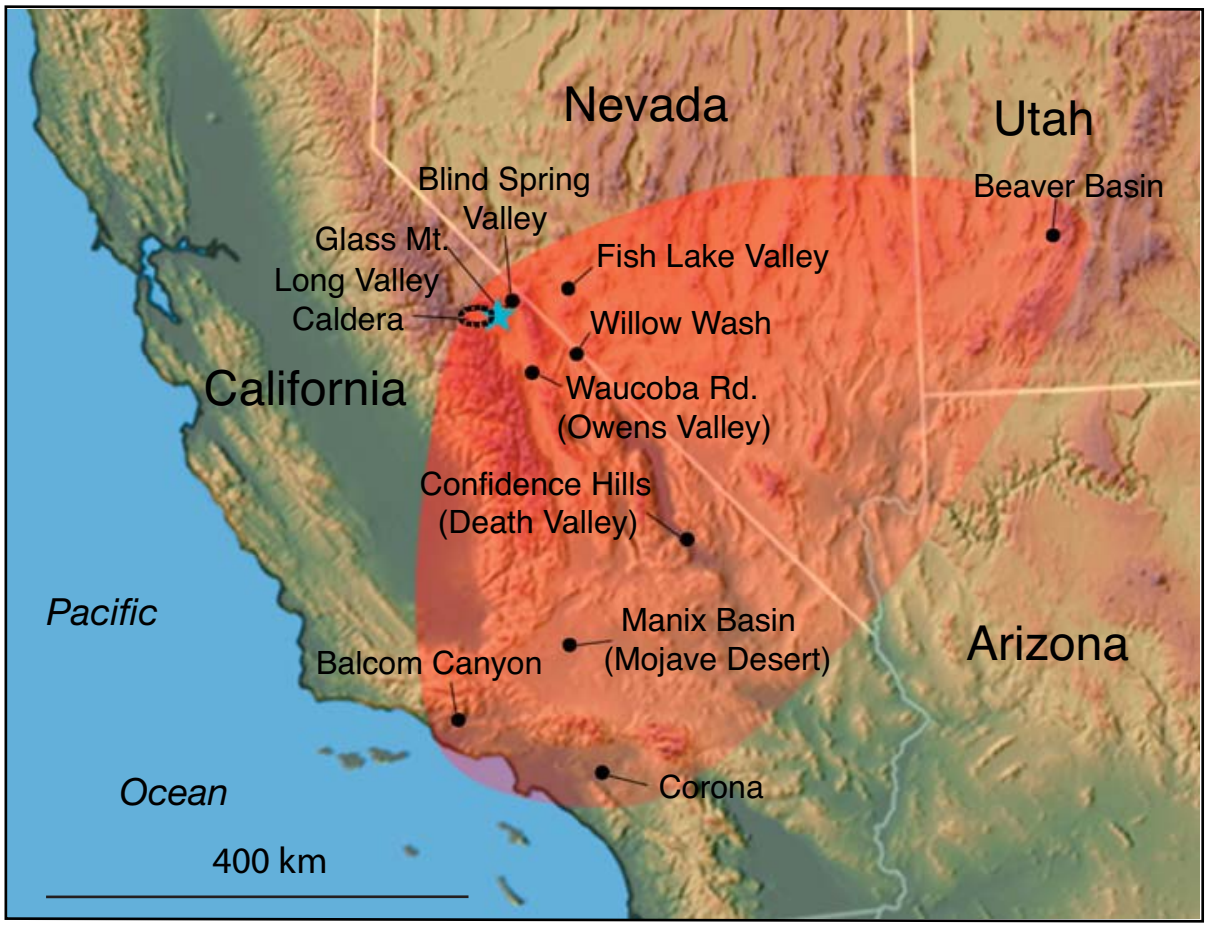

Figure 1. Localities at which tuffs of Blind Spring Valley and stratigraphically closely related tephra layers were sampled (small circles); location of Glass Mountain, near source of the tuffs of Blind Spring Valley (star), and location of Long Valley Caldera (oval outlined by dashes). Red shaded pattern represents known distribution of tuffs of Blind Spring Valley. 
$\sim 2.8$ million years ago, have produced thick deposits of rhyolitic lava flows and tephra in the vicinity of Glass Mountain (Bailey and others, 1976; Metz and Mahood, 1985, 1991), and a widespread apron of roughly coeval tephra and volcaniclastic dome-collapse deposits to the north and northeast of Glass Mountain, referred to as the tuff of Taylor Canyon (Krauskopf and Bateman, 1977) (fig. 2). Volcanism at Glass Mountain culminated with the voluminous, climactic eruption of the Bishop Tuff at about $0.76 \mathrm{Ma}$, forming the Long Valley Caldera and truncating the southwestern flank of Glass Mountain along ring fractures, dropping it down to the southwest, where it now lies covered by younger volcanic rocks and sediments (Gilbert, 1938; Bailey and others, 1976; Metz and Mahood, 1985; Hildreth, 1979, Wilson and Hildreth, 1997). Thus, a section of unknown thickness of Glass Mountain rhyolites and equivalent tephra and volcaniclastic debris correlative with the tuff of Taylor Canyon of Krauskof and Bateman (1977) may be buried beneath the later Bishop Tuff and younger volcanic rocks that filled the subsided Long Valley Caldera. The rhyolites of Glass Mountain remain exposed on the east and northeast wall of the Long Valley Caldera and to the northeast. Silicic volca- nism in the Long Valley Caldera resumed shortly after eruption of the Bishop Tuff and has continued intermittently until at least $\sim 0.1 \mathrm{Ma}$ (Bailey and others, 1976). Volcanic activity has continued in the western part of the Long Valley Caldera, at the Inyo Craters, and to the north at the Mono Craters, into Holocene time (Bailey and others, 1976; Lajoie, 1968).

\section{Tephra Layers of Blind Spring Valley at the Cowan Pumice Mine}

The tephra layers of Blind Spring Valley are exposed at the Cowan Pumice Mine in Blind Spring Valley, about $17 \mathrm{~km}$ east of glass Mountain (figs. 2, 3). These layers consist of coarse air-fall tephra and tephra layers partly reworked by sheetwash. The tephra layers of Blind Spring Valley are a complex unit consisting of several thick, coarse air-fall tephra layers. These pyroclastic layers have been previously correlated by Izett and others (1988) with the tuff of Taylor Canyon of Krauskopf and Bateman (1977). The tuff of Taylor Canyon at the type locality designated by Krauskopf and Bateman (1977), however, con-

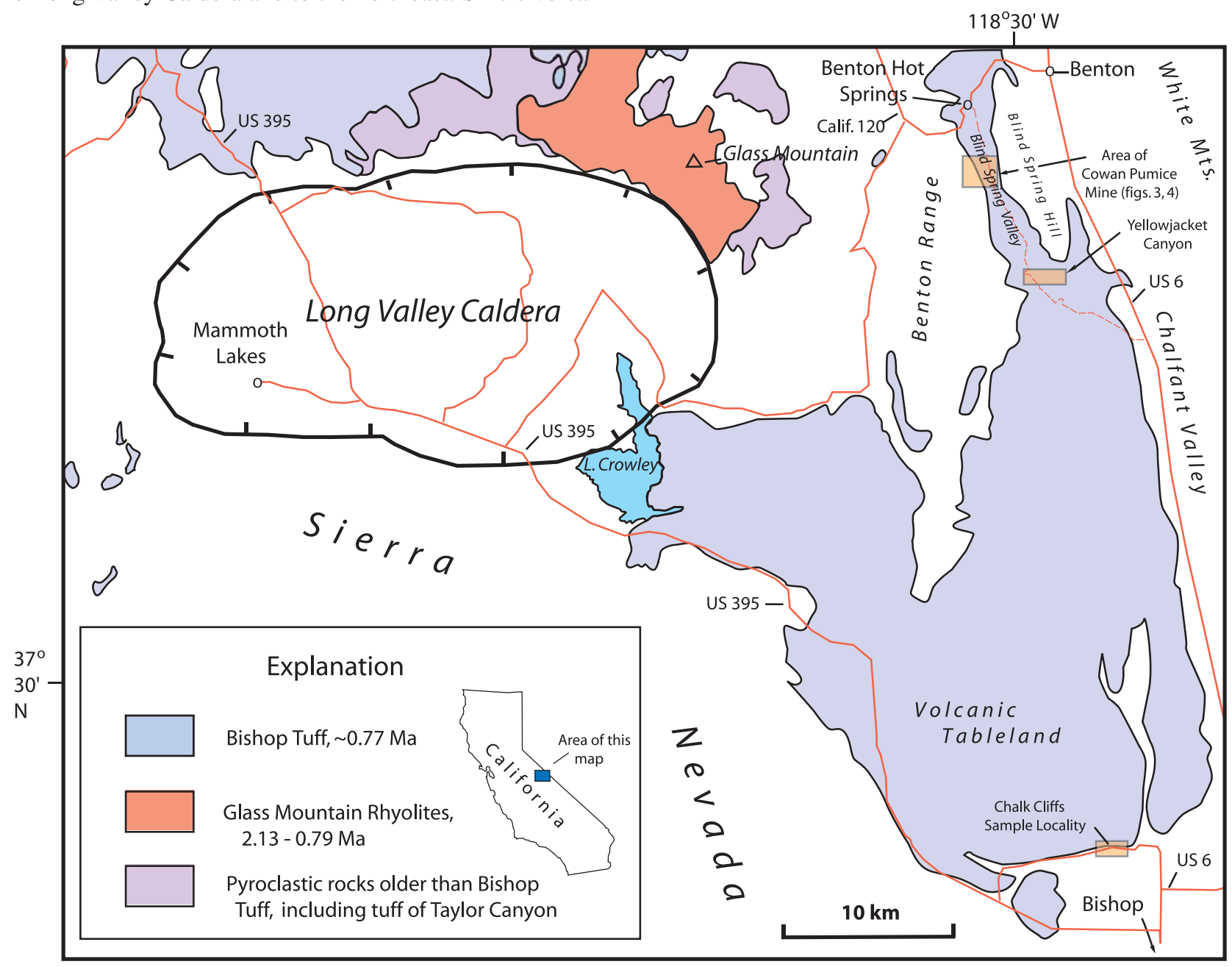

Figure 2. Generalized geologic map of the area of Long Valley Caldera, Glass Mountain, the Cowan Pumice Mine, and south end of Volcanic Tableland (Chalk Cliffs locality). Compiled and revised from Metz and Mahood (1985, 1991), and Wilson and Hildreth (1997). Major roads shown in red. 
sists of coarse, obsidian-bearing pumice air-fall and reworked tephra and other pyroclastic deposits correlative with, and temporally equivalent to, the rhyolites of Glass Mountain (Metz and Mahood, 1985; Metz and Mahood, 1991). Tephra layers correlated by us with the rhyolites of Glass Mountain on the basis of chemical composition and isotopic ages at the Cowan Pumice Mine overlie tephra layers of Blind Spring Valley, have younger isotopic ages and different chemical composition than the tephra layers of Blind Spring Valley. The tephra layers of Blind Spring Valley may have been erupted from the same area as the rhyolites of Glass Mountain. However, no proximal flows or tephra of the same age and composition as the tuffs of Blind Spring Valley are known to underlie the rhyolites of Glass Mountain at the source area near Glass Mountain.

The tuffs of Blind Spring Valley were well exposed in several quarry pits (filled in sometime shortly before the fall of 1995 and thus no longer accessible for study) at the Cowan Pumice Mine. They consist of thick beds of airfall pumice layers, intercalated with minor reworked tephra layers and tuffaceous alluvium, tuffaceous mudflows and debris flows, and reworked tuffaceous eolian deposits. Much of the area intervening between the pumice pits is poorly exposed and complicated by normal faulting, so correlation of tephra units among the pits is not straightforward (figs. 3, 4).

Pumice lapilli in tephra layers at the Cowan Pumice Mine contain large crystals of sanidine feldspar. Analysis of sanidines from pumice, rather than from the fine ashy matrix of distal tephra layers, allowed us to eliminate detrital feldspar grains from analysis. Laser-fusion ${ }^{40} \mathrm{Ar} /{ }^{39} \mathrm{Ar}$ analysis further allowed us to obtain ages on individual grains or small groups of several grains of a mineral (York and others, 1981; LoBello and others, 1987; Dalrymple, 1989), to determine the degree of internal scatter for ages of each tephra layer, and thus to evaluate the age analysis for possible accidental contamination-presence in the sample of older xenoxrystic mineral grains torn from the walls of the magma chamber or volcanic vent during eruption. Lastly, overall coherence of the dates was checked against their relative stratigraphic positions, to test their consistency.

Because tephra at the Cowan Pumice Mine consists of coarse pumice fall deposits, finer-grained correlative layers are likely to be present at sites farther away. Ages determined on the proximal tephra layers can be correlated to the distal layers by means of their chemical and petrographic characteristics. We have performed petrographic analyses of the tephra layers, and

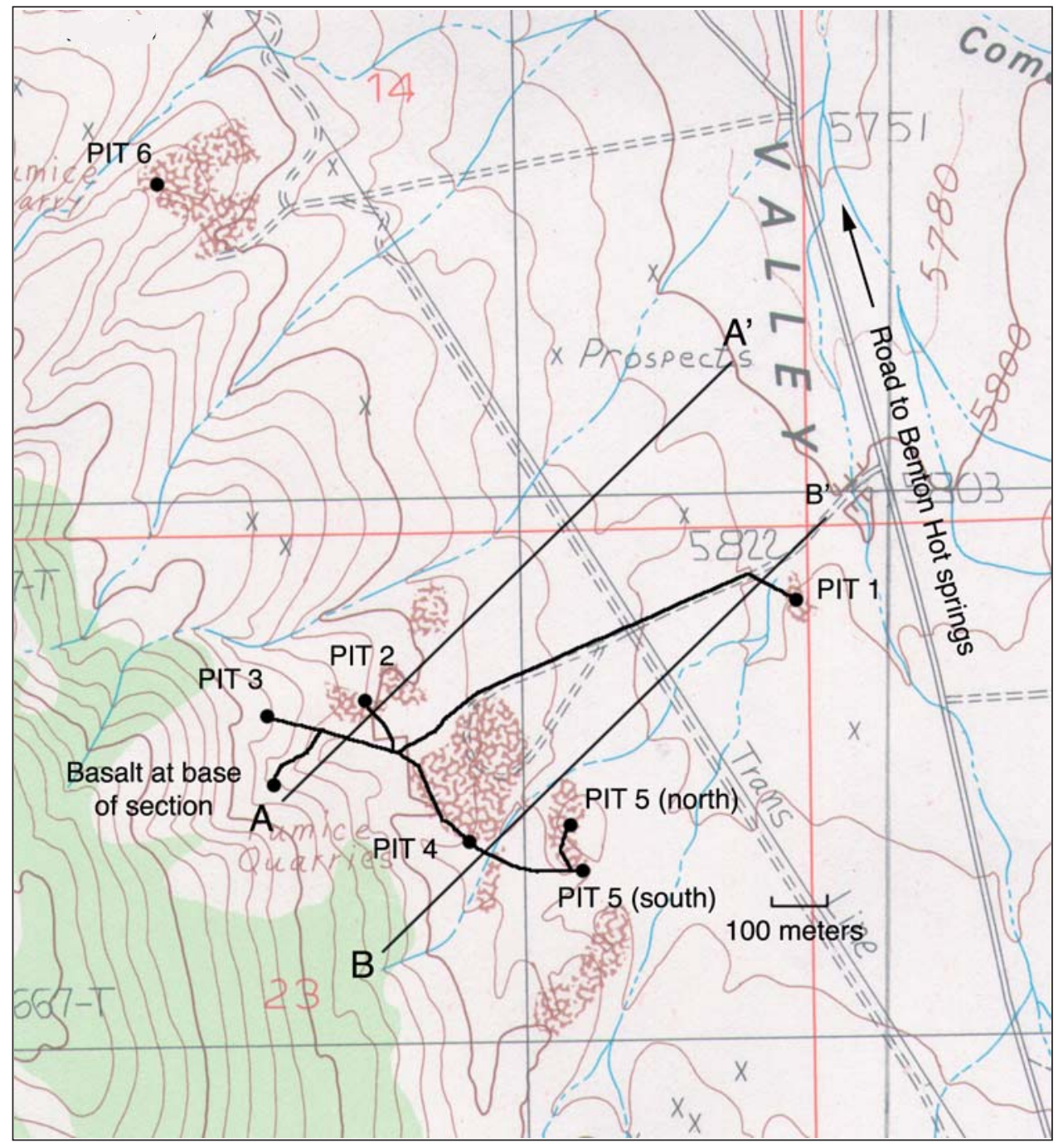

Figure 3. Locations of pumice pits (black dots) at Cowan Pumice Mine and of cross-sections A-A' and B-B' (straight black lines; see fig. 4 ). Irregular black lines connecting Pits 1-5 are surveyed lines. Base from U.S. Geological Survey Benton Hot Springs 7.5' quadrangle (provisional edition, 1986). 
chemical analyses on volcanic glasses of the tephra layers, from the Cowan Pumice Mine, and results of these analyses were compared with those of tephra samples collected from other areas in the western conterminous United States. Fine-grained tephra layers of essentially the same chemical composition and age as those at the Cowan Pumice Mine are identified at multiple sites over a large area in the western United States. These correlations indicate that the Glass Mountain volcanic center was an important source of recurrent, explosive silicic volcanism in late Pliocene time and that tephra erupted from this general vicinity provides chronostratigraphic marker beds of regional extent, from the Pacific borderland to central Utah. The exact location of some of the sources active before about $2 \mathrm{Ma}$ is still unknown.

\section{Tephra Layers from Other Source Areas in the Western United States}

The Huckleberry Ridge ash bed, erupted from the Yellowstone area of northwestern Wyoming and east-central
Idaho (Christiansen and Blank, 1972; Izett, 1981; Izett and Wilcox, 1982; Sarna-Wojcicki and others, 1984), underlies the lower tuffs of Glass Mountain and the tuffs of Emigrant Pass and overlies the tuff of Blind Spring Valley at several localities in eastern California, western Nevada, and western Utah. This tephra layer provides an independent chronostratigraphic marker to test correlations based on chemical and petrographic characteristics.

\section{Acknowledgements}

We thank John D. Obradovich for providing us with a near-source sample of the Huckleberry Ridge Tuff (68-O-40). We thank Roy Bailey, Wes Hildreth, and Peter Stauffer of the U.S. Geological Survey, Menlo Park, California, for improving the content and clarity of the manuscript. We also thank Judy E. Fierstein for performing calculations to estimate the volume of the tuffs of Blind Spring Valley.
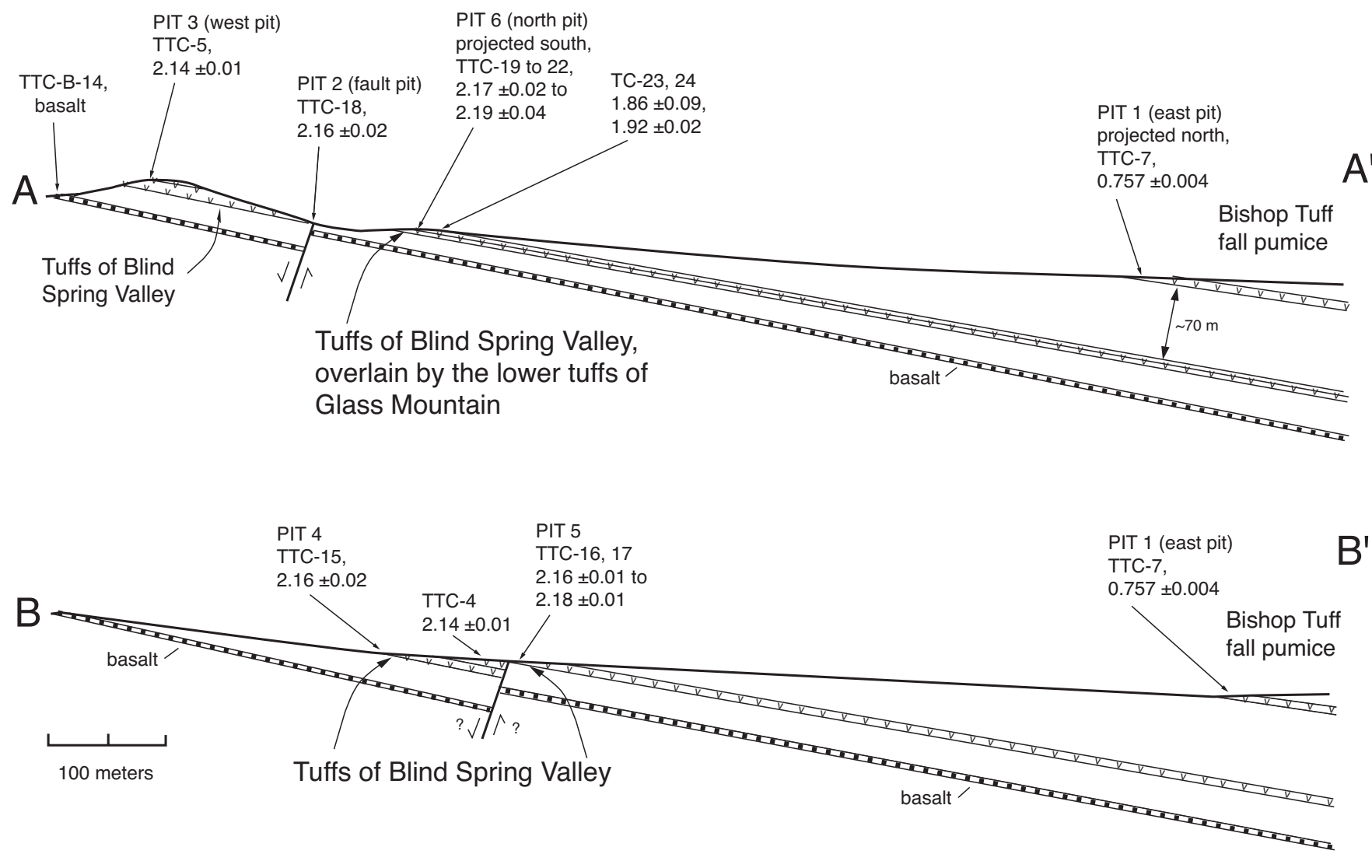

Figure 4. Cross sections $A-A^{\prime}$ and B-B' in area of Cowan Pumice Mine, Blind Spring Valley, with locations and ${ }^{40} \mathrm{Ar} /{ }^{39} \mathrm{Ar}$ ages (in Ma) of samples in Pits 1-6. Presence and position of fault in cross-section B-B' are inferred. See figure 3 for locations of sections. 


\section{Previous Work}

Gilbert and others (1968) mapped and described the geology southeast of Mono Lake, Calif., and determined many K$\mathrm{Ar}$ ages on late Tertiary volcanic units in this region. Among these were ages on basalts ( 4.2 to $2.6 \mathrm{Ma}$ ) that underlie the late Pliocene and Pleistocene silicic volcanic rocks erupted from the Long Valley-Glass Mountain volcanic center south and east of Mono Basin and an age for a rhyolite near the top

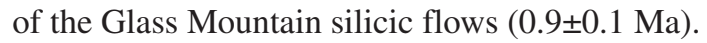

Bailey and others (1976) studied the volcanism, structure, and geochronology of the Long Valley Caldera in east-central California. Although the focus of their study was the younger volcanic rocks of the Long Valley Caldera that postdated the eruption of the Bishop Tuff, they also obtained an age of $1.92 \pm 0.05 \mathrm{Ma}$ on a biotite rhyolite of Glass Mountain, in the lower part of the silicic volcanic pile, on the southwest side of Glass Mountain. This age, together with that of Gilbert and others (1968), defined at that time the range of Glass Mountain volcanism to between $\sim 1.92$ and $\sim 0.9$ Ma.

Krauskopf and Bateman (1977) named the tuff of Taylor Canyon after a canyon about $20 \mathrm{~km}$ northwest of the Cowan pumice mine (the site studied in this report). They mapped the tuff of Taylor Canyon as a dissected sheet of tephra layers spread over a broad area to the north and east of Glass Mountain.

Sarna-Wojcicki and others $(1980,1984)$, chemically analyzed and correlated a suite of tephra layers in eastern and southern California and proposed that these layers were erupted from the Long Valley-Glass Mountain volcanic province of east-central California. These authors showed that there was a systematic, age-related trend in the chemical composition of the volcanic glasses of this suite: an increase in the siderophile elements, and a decrease in the lithophile elements, from older to younger layers. They also correlated a tephra layer of the Long Valley-Glass Mountain type in the Waucoba Lake beds of Owens Valley with a layer in the Manix Basin of the Mojave Desert, and they correlated a closely underlying ash bed at the latter site with the Huckleberry Ridge ash bed, which had been previously dated elsewhere at about $2 \mathrm{Ma}$ (Izett and Wilcox, 1982)

Izett (1981), and Izett and others (1988) analyzed two ash layers from the Cowan pumice mine, which were designated Taylor Canyon-P (lower) and -C (upper) beds. According to Izett and others (1988), a third bed, designated Taylor Canyon $\mathrm{U}$, was the uppermost of three tephra layers from Yellowjacket Canyon, located about $6.5 \mathrm{~km}$ southeast of the Cowan Mine, and was considered to be the uppermost of the sequence of their Taylor Canyon beds. Their Taylor Canyon-P corresponds to TTC-6 of the tuff of Blind Spring Valley of this report, and Taylor Canyon-C corresponds to TTC-4 of the tuff of Blind Spring Valley, both in Pit 5 (p. 26 of Izett and others, 1988). Their Taylor Canyon-P and -C may also correspond to our TTC-21 and 22 of the tuff of Blind Spring Valley, respectively, in Pit 6 (p. 27 of Izett and others, 1988). Izett and others $(1982,1988)$ obtained an age of $2.10 \pm 0.02 \mathrm{Ma}$ on the Tay- lor Canyon-C bed from the Cowan Pumice Mine, using the conventional $\mathrm{K}-\mathrm{Ar}$ method on sanidine. These authors have also correlated the Taylor Canyon-C and -P ash beds to several other localities in the vicinity of Bishop, Calif. Moreover, they correlated Taylor Canyon-C to one or more ash beds in the Waucoba Lake beds of central Owens Valley (Izett and others, 1988; their sample 79G25 may be equivalent to our WAC-6 and WAC-7, and their sample 79G29 is probably equivalent to our W2A, in the Waucoba Lake Beds) and to a tephra layer in Beaver Basin west-central Utah, where the layer underlies the Huckleberry Ridge ash bed.

As mentioned above, Izett and others (1988) used the term "Taylor Canyon beds" for the thick, coarse air-fall tephra beds at the Cowan Pumice Mine, assuming that these were correlative to the tuff of Taylor Canyon of Krauskopf and Bateman (1977). In this report, we show that the tuff of Taylor Canyon of Krauskopf and Bateman at the type locality in Taylor Canyon is not correlative to the coarse air-fall tephra beds at Cowan Pumice Mine, because they differ in petrographic characteristics, chemical composition, and isotopic age. Consequently, the name "Taylor Canyon" is not appropriate for these coarse air-fall deposits at the Cowan Pumice Mine, and we renamed them informally as "the tuffs of Blind Spring Valley," after the valley in which they are found.

Metz and Mahood (1985) conducted a geochronologic and petrologic study of Glass Mountain, the source area of Glass Mountain tephra and of the tuff of Taylor Canyon. This source is located about $17 \mathrm{~km}$ west of the Cowan Pumice Mine. Metz and Mahood obtained $38 \mathrm{~K}-$ Ar ages on lava flows, mostly on glass and felsite, and showed that the Glass Mountain volcanic center had been active from about 2.13 to about $0.79 \mathrm{Ma}$. Two episodes of volcanism were inferred for the Glass Mountain volcanic center by these authors: sporadic eruptions during an early episode of activity from about 2.1 to $1.2 \mathrm{Ma}$ and a later, more voluminous and sustained episode from 1.1 to $0.8 \mathrm{Ma}$. These authors confirmed observations by Sarna-Wojcicki and others (1984) that the eruptive products of the Long Valley-Glass Mountain volcanic area became less evolved with time, and that the subsequently erupted Bishop Tuff had the least evolved (though still highly silicic) composition of all units in this suite

Troxel (1986) described a thick section of deformed, upper Pliocene to early Pleistocene (?) lacustrine and fluvial sediments in the Confidence Hills of Death Valley, Calif., and Troxel and others (1986) presented chemical data for three of the thickest tephra layers, the lowermost of about 25 tephra layers that are present within this section. On the basis of the chemical composition of the volcanic glass shards, the basal of these three tephra layers was correlated with a tephra layer in the Waucoba lake beds in Owens Valley and with the tephra layers of the tuff of Blind Spring Valley. The middle layer was correlated with the Huckleberry Ridge ash bed ( 2.0 Ma; Izett and Wilcox, 1982); the upper layer was chemically very similar to the lowermost layer, and Troxel and others speculated that the section may have been repeated by isoclinal folding. Data presented here identifies this third, uppermost tephra layer as one of the tuffs 
of Emigrant Pass, and discounts the possibility of isoclinal folding. In this study, we have examined the remaining tephra layers in the Confidence Hills section, and present analyses of those layers that are not altered or devitrified.

The section exposed in the Confidence Hills of Death Valley was subsequently studied by Beratan and Murray (1992), who further described its stratigraphy and lithology, and by Pluhar and others (1992), who determined its magnetostratigraphy. Pinning their chronology to the identified Huckleberry Ridge ash bed of Troxel and others (1986), Pluhar and others identified the Reunion events and the Olduvai Normal Subchron within the Matuyama Reversed Chron. Using the new, revised ages of these magnetostratigraphic datum levels and interpolation, these authors then obtained a revised age for the Huckleberry Ridge ash bed of 2.09 Ma.

Reheis and others (1991) presented data on the structure, stratigraphy, magnetostratigraphy, chemical composition, and tephrostratigraphy of about 55 tephra layers within a thick, composite late Cenozoic sedimentary and volcanic section at Willow Wash, south of Fish Lake Valley, about 90 km southeast of Glass Mountain, in eastern California. They tentatively identified several widespread tephra layers within this section that ranged in age from about 5.4 to $0.74 \mathrm{Ma}$, including tephra layers of the tuff of Blind Spring Valley. The lower tephra layers of Glass Mountain were also identified above the tuffs of Blind Spring Valley, near the top of the section. Tephra layers in the uppermost part of the section at Willow Wash were tentatively identified as reworked Bishop ash bed, but data presented below indicate that these layers are older than the Bishop ash bed, and are probably not younger than about 1.79 Ma. Additional tephra layers were identified below the tuffs of Blind Spring Valley, including the tuffs of Benton Hot Springs (equivalent to the Rimrock ash beds), the Nomlaki and Putah Tuffs, and the tuffs of Mesquite Springs.

Reheis and others (1993) documented the petrographic and chemical characteristics, correlations, and ages of multiple tephra layers in late Pliocene sediments of northeastern Fish Lake Valley, Nev., about $70 \mathrm{~km}$ east of Glass Mountain, near Emigrant Pass. They identified the tuffs of Blind Spring Valley in lacustrine sediments, overlain by transitional lacustrine-alluvial sediments containing the Huckleberry Ridge ash bed (from the Yellowstone area of northwestern Wyoming and east-central Idaho), in turn overlain by the tuffs of Emigrant Pass, and, in turn, coarse fan gravels containing tephra layers of Glass Mountain. The latter, in turn, are overlain by the Bishop ash bed, present in beach sands of a younger, mid-Pleistocene lake.

Metz and Mahood (1991) described the development of the Long Valley magma chamber as recorded in the rhyolitic lavas of the Glass Mountain volcanic center. They present multiple major-, minor-, and trace-element analyses of lavas from this center. They have, as in their 1985 report, divided the rhyolites into two groups, an earlier eruptive episode of highly evolved but compositionally variable older lavas ( 2.1 to 1.2 $\mathrm{Ma})$ and a later episode of slightly less evolved, but more homogenous lavas ( 1.2 to $0.79 \mathrm{Ma})$. From comparison of the analyses in Metz and Mahood (1991) and those presented in this report, the rhyolites of Glass Mountain of Metz and Mahood (1991) correspond to the tuffs of Glass Mountain presented here almost in their entirety, with the exeption that the oldest dated rhyolite of Glass Mountain of Metz and Mahood (1991), OG-200, 2.13 Ma, may correlate with our tuffs of Emigrant Pass, which overlie the youngest tuffs of Blind Spring Valley (<2.135 Ma, >2.09 Ma) and the undated OFCT75-6 of Metz and Mahood (1991; a sample of R. Bailey, cited in the latter report), may correlate with the tuffs of Blind Spring Valley reported here.

\section{Analytical Methods}

\section{Field Methods}

Stratigraphic sections were measured and described in the pumice pits, and samples of tephra layers were collected for age and chemical analysis (figs. 2-4). Angular obsidian clasts were hand-picked from some tephra layers at the outcrops. Topographic transects were conducted between the pits (fig. 3) and stratigraphic cross sections drawn to correlate tephra units among the pits (fig. 4). Similar work was conducted at other sites within the region and at more distal sites, where putative correlative tephra layers were present (fig. 1,2).

\section{Laboratory Preparation of Samples for Analysis}

In the laboratory, the samples were disaggregated or crushed and wet-sieved in plastic sieves using 100, 200, and 325 nylon mesh screens (opening diameters of 150, 80, and $45 \mu$, respectively). Plastic and nylon were used to avoid contamination with metals. Sized fractions were then cleaned chemically, first with $10 \% \mathrm{HCl}$, then very briefly with $8 \%$ $\mathrm{HF}$, and in an ultrasonic bath in deionized water. They were then separated using magnetic and heavy-liquid methods into component parts_-volcanic glass shards, magnetic minerals, nonmagnetic minerals, and lithic grains. Sanidine grains and, in a few instances, obsidian clasts were separated from the tephra samples for laser-fusion ${ }^{40} \mathrm{Ar} /{ }^{39} \mathrm{Ar}$, and for $\mathrm{K}$-Ar dating, respectively. Individual euhedral or glass-coated feldspar grains were hand-picked from the concentrates and further etched for several minutes with $10 \% \mathrm{HF}$ for laser-fusion ${ }^{40} \mathrm{Ar} /{ }^{39} \mathrm{Ar}$ analysis.

\section{Laser-fusion ${ }^{40} \mathrm{Ar} /{ }^{39} \mathrm{Ar}$ and Conventional K-Ar Analyses}

Sanidine and plagioclase crystals were separated from pumice clasts, as described above, and hand-picked if necessary. After packaging and irradiation as described in SarnaWojcicki and others (2000), and after heating and cleanup, the samples were analyzed using the $\mathrm{W}$ argon laser system at the U.S. Geological Survey, Menlo Park, Calif., using methods described by Dalrymple (1989). 
All ages reported herein are relative to $27.92 \mathrm{Ma}$ for the TCR (Taylor Creek) sanidine 85G003 (Dalrymple and Duffield, 1988). Ages in the range 0 to $2.5 \mathrm{Ma}$ originally calculated using this value of 27.92 Ma for the TCR (and the related value of 514.0 Ma for the MMhb-1) can be recalculated to other values of TCR or MMhb-1 used in the current literature. Thus, for example, the 0.759-Ma age of the Bishop Tuff (Sarna-Wojcicki and others, 2000) becomes 0.774 Ma using values recommended by Renne and others (1998). Errors are reported as the standard deviation of analytical precision, unless otherwise stated. Obsidian clasts separated from tephra layers were analyzed using methods described for conventional K-Ar analysis (for example, Dalrymple and Lanphere, 1969).

Analytical data for all laser-fusion ${ }^{40} \mathrm{Ar} /{ }^{39} \mathrm{Ar}$ runs are presented in appendix 1. Analytical data for the two conventional $\mathrm{K}-\mathrm{Ar}$ runs are presented in appendix 2.

\section{Chemical Analysis of Volcanic Glass Shards}

Volcanic glasses separated from all tephra samples were analyzed by electron-microprobe (EM), and glasses from selected samples was also analyzed by energy-dispersive $\mathrm{X}$-ray fluorescence (XRF) and instrumental neutron-activation analyses (INAA). Ages, stratigraphic and petrographic data, and chemical compositions of the tephra samples were compared with those of other tephra layers from the western United States, and correlations were noted if the requisite criteria for correlation were considered to be fully met (see section on methods of data evaluation, below).

\section{Electron-microprobe (EM) Analysis}

Methods used in EM analysis of glass shards are described in Sarna-Wojcicki and others (1984). The current database of the U.S. Geological Survey's Tephrochronology Laboratory (Menlo Park) contains $~ 5000$ EM analyses of tephra samples from the conterminous western United States that can be used for comparison and correlation. These EM analyses were determined over a period of $\sim 25$ years on three different instruments: ARL, SEQM, and JEOL8900 microprobes. With the JEOL8900 microprobe, we use a $10-\mu$ beam diameter, $10.05-n A, 15-K V$ beam current. Acquisition time is 10 seconds for $\mathrm{Na}$, and 20 seconds for the remaining elements: $\mathrm{Si}, \mathrm{Al}, \mathrm{Fe}, \mathrm{Mg}, \mathrm{Mn}, \mathrm{Ca}$, Ti, and $\mathrm{K}$. We use GSC (Corning Glass Standard) and An40 (anorthite) as standards, and RLS-132, a homogenous obsidian from La Puebla, Mexico, as an internal standard. The ZAF data-reduction program is used to obtain oxide concentrations. Replicate analyses of internal and external standards over the past 25 years indicate that analyses are mutually compatible, despite differences in instrumentation (table 1). Precision and accuracy of the analyses for each oxide are indicated by replicate analysis of RLS-132 and by comparative values from wet-chemical analysis. Data for $\mathrm{P}, \mathrm{Cl}$, and $\mathrm{Ba}$ are available for some samples, but are generally not helpful in chemical characterization of the silicic tephra layers in this study using EM analysis. Similarly, $\mathrm{MgO}, \mathrm{MnO}$, and $\mathrm{TiO}_{2}$ are not consistently useful in characterization of silicic tephra by this method owing to low concentrations in some of the volcanic glasses and consequently relatively large scatter in analyzed values (Sarna-Wojcicki and Davis, 1991). Despite these drawbacks, EM analysis makes it possible to determine the chemical composition of individual glass shards for the above major and minor oxides, and thus to determine the homogeneity of tephra samples and detect presence of multiple compositional modes (Sarna-Wojcicki and Davis, 1991).

Internal, polished surfaces of about 15 to 20 individual glass shards were analyzed for each sample. When EM analysis was not diagnostic for characterizing some tephra layers, or when other criteria for correlation such as numerical age, stratigraphic position, or petrographic characteristics were lacking or inadequate to achieve a reliable identification of a tephra layer, followup chemical analyses were conducted using energy-dispersive $\mathrm{X}$-ray fluorescence or instrumental neutron-activation analysis.

\section{Energy-dispersive X-ray Fluorescence (EDXRF) Analysis}

About $0.5 \mathrm{~g}$ of pure volcanic glass was powdered and analyzed, together with previously analyzed standards, using a Kevex 0700/8000 EDXRF spectrometer. Methods used are described in Johnson and King (1987). Analyses included $\mathrm{Fe}_{2} \mathrm{O}_{3}, \mathrm{MnO}, \mathrm{CaO}, \mathrm{TiO}_{2}, \mathrm{~K}_{2} \mathrm{O}$, and $\mathrm{Rb}, \mathrm{Sr}, \mathrm{Y}, \mathrm{Zr}$, and $\mathrm{Nb}$. In this type of analysis, cross-checks with results obtained by EM analysis are made for $\mathrm{Fe}_{2} \mathrm{O}_{3}, \mathrm{CaO}$, and $\mathrm{K}_{2} \mathrm{O}$, generally more precise concentrations are obtained for $\mathrm{MnO}$ and $\mathrm{TiO}_{2}$ than in $\mathrm{EM}$ analysis, and the other minor and trace elements provide additional critical variables to discriminate among tephra layers. The current database of the U.S. Geological Survey's Tephrochronology Project (Menlo Park) contains 800 EDXRF analyses of tephra samples from the conterminous western United States; an additional $\sim 700$ analyses by wavelength-dispersive (WD) XRF analysis from the database of the University of Utah (collection of F. H. Brown and M. E. Perkins, Department of Geology and Geophysics) are available for comparison.

\section{Instrumental Neutron Activation (INA) Analysis}

Between 0.2 and $0.5 \mathrm{~g}$ of pure volcanic glass was powdered and analyzed using techniques described in Bowman and others (1973), Sarna-Wojcicki and others (1979), and Baedecker and McKown (1987). Currently, there are 500 INA analyses of tephra samples in the database of the Tephrochronology Laboratory (Menlo Park) that can be used for comparison. These samples were analyzed over a period of about 20 years in three different laboratories: Lawrence Berkeley Laboratory of the University of California and the Radiochemistry Laboratories of the U.S. Geological Survey in Reston, Va., and in Denver, Colo. Of the three methods (EM, EDXRF, and INA), INA analysis is by far the most precise for a number of minor and trace elements. Analyses were made for 24 or more elements; between 15 and 20 of these generally proved useful in characterizing 
Table 1. Chemical composition of volcanic glass shards determined by electron-microprobe analysis, and ages of tephra layers sampled from quarry pits at the Cowan Pumice Mine, near Benton Hot Springs, Calif.

[Tephra layers are in stratigraphic order (from uppermost to lowermost), or in inferred stratigraphic position, based on projections into cross-sections. Oxide concentrations are in weight-percent oxide, recalculated to 100 percent. Original oxide totals before recalculation are given to indicate approximate degree of hydration of volcanic glass. About 15 individual glass shards were analyzed for each sample. Comparative composition of a homogenous natural glass, RLS 132, used as an internal standard, is also given, providing information on precision and accuracy of the analyses. Ages by laser-fusion ${ }^{40} \mathrm{Ar} /{ }^{39} \mathrm{Ar}$ method, except for TTC-7*, which is by fission-track on zircons, and TTC-24*, which is by conventional K-Ar on obsidian clasts. Electron-microprobe chemical analyses by C. E. Meyer; laser-fusion ${ }^{40} \mathrm{Ar}{ }^{39} \mathrm{Ar}$ analyses by M. A. Pringle; K-Ar analyses by J. A. Nakata; fission-track analyses by C. E. Meyer and Marta Woodward.]

\begin{tabular}{|c|c|c|c|c|c|c|c|c|c|c|c|}
\hline Sample & $\mathrm{SiO}_{2}$ & $\mathrm{Al}_{2} \mathrm{O}_{3}$ & $\mathrm{Fe}_{2} \mathrm{O}_{3}$ & $\mathrm{MgO}$ & MnO & $\mathrm{CaO}$ & $\mathrm{TiO}_{2}$ & $\mathrm{Na}_{2} \mathrm{O}$ & $\mathrm{K}_{2} \mathrm{O}$ & Total & Age (Ma) \\
\hline \multicolumn{12}{|c|}{ Bishop airfall pumice bed; Pit 1} \\
\hline TTC-7 & 77.3 & 12.7 & 0.82 & 0.09 & 0.04 & 0.54 & 0.09 & 3.71 & 4.76 & 94.0 & $0.757 \pm 0.004$ \\
\hline TTC-7* & & & & & & & & & & & $0.75 \pm 0.05$ \\
\hline \multicolumn{12}{|c|}{ Lower tuffs of Glass Mountain; Pit 6} \\
\hline TTC-24* & 77.7 & 12.6 & 0.71 & 0.04 & 0.02 & 0.39 & 0.05 & 3.79 & 4.69 & 95.8 & $1.857 \pm 0.085$ \\
\hline TTC-23 & 77.6 & 12.6 & 0.71 & 0.03 & 0.03 & 0.32 & 0.03 & 3.58 & 5.10 & 95.1 & $1.922 \pm 0.024$ \\
\hline \multicolumn{12}{|c|}{ Tuffs of Blind Spring Valley } \\
\hline \multicolumn{12}{|c|}{ Thick, coarse bed; Pit 2} \\
\hline TTC-18 & 77.9 & 12.5 & 0.59 & 0.05 & 0.10 & 0.35 & 0.07 & 3.45 & 5.09 & 93.8 & $2.135 \pm 0.022$ \\
\hline \multicolumn{12}{|c|}{ Thick coarse bed; Pit 3; } \\
\hline TTC-5 & 77.3 & 12.8 & 0.59 & 0.05 & 0.09 & 0.35 & 0.10 & 3.80 & 4.93 & 92.5 & $2.139 \pm 0.007$ \\
\hline \multicolumn{12}{|c|}{ Thick, coarse bed; Pit 5 (south side) } \\
\hline TTC-13 & 78.0 & 12.6 & 0.58 & 0.05 & 0.10 & 0.36 & 0.05 & 3.79 & 4.51 & 92.2 & nd \\
\hline TTC-4 & 77.5 & 12.6 & 0.59 & 0.03 & 0.09 & 0.37 & 0.06 & 4.13 & 4.61 & 94.0 & $2.140 \pm 0.005$ \\
\hline \multicolumn{12}{|c|}{ Thin tephra beds; Pit 5 (south side) } \\
\hline TTC-12 & 77.7 & 12.7 & 0.62 & 0.06 & 0.09 & 0.38 & 0.07 & 3.81 & 4.58 & 93.6 & nd \\
\hline TTC-11 & 77.8 & 12.6 & 0.60 & 0.05 & 0.08 & 0.37 & 0.06 & 3.86 & 4.60 & 94.2 & nd \\
\hline TTC-10 & 77.8 & 12.5 & 0.61 & 0.06 & 0.08 & 0.37 & 0.08 & 3.69 & 4.83 & 93.9 & nd \\
\hline TTC-9A & 77.5 & 12.8 & 0.59 & 0.05 & 0.10 & 0.34 & 0.07 & 3.87 & 4.65 & 93.0 & nd \\
\hline TTC-9 & 77.6 & 12.7 & 0.58 & 0.04 & 0.10 & 0.34 & 0.07 & 3.69 & 4.88 & 93.2 & nd \\
\hline \multicolumn{12}{|c|}{ Thin airfall (?) beds; Pit 4} \\
\hline TTC-15 & 77.9 & 12.6 & 0.57 & 0.05 & 0.09 & 0.35 & 0.05 & 3.88 & 4.57 & 93.5 & $2.153 \pm 0.008$ \\
\hline \multicolumn{12}{|c|}{ Coarse, thick bed; Pit 5 (south side) } \\
\hline TTC-8 & 77.5 & 12.8 & 0.58 & 0.05 & 0.11 & 0.34 & 0.05 & 3.69 & 4.88 & 93.2 & nd \\
\hline TTC-6 & 77.2 & 12.9 & 0.58 & 0.05 & 0.09 & 0.33 & 0.09 & 4.08 & 4.64 & 94.6 & nd \\
\hline
\end{tabular}


Table 1. Chemical composition of volcanic glass shards determined by electron-microprobe analysis, and ages of tephra layers sampled from quarry pits at the Cowan Pumice Mine, near Benton Hot Springs, Calif.-Continued

[Tephra layers are in stratigraphic order (from uppermost to lowermost), or in inferred stratigraphic position, based on projections into cross-sections. Oxide concentrations are in weight-percent oxide, recalculated to 100 percent. Original oxide totals before recalculation are given to indicate approximate degree of hydration of volcanic glass. About 15 individual glass shards were analyzed for each sample. Comparative composition of a homogenous natural glass, RLS 132, used as an internal standard, is also given, providing information on precision and accuracy of the analyses. Ages by laser-fusion 40Ar/39Ar method, except for TTC-7*, which is by fission-track on zircons, and TTC-24*, which is by conventional K-Ar on obsidian clasts. Electron-microprobe chemical analyses by C. E. Meyer; laserfusion 40Ar/39Ar analyses by M. A. Pringle; K-Ar analyses by J. A. Nakata; fission-track analyses by C. E. Meyer and Marta Woodward.]

\begin{tabular}{|c|c|c|c|c|c|c|c|c|c|c|c|}
\hline Sample & $\mathrm{SiO}_{2}$ & $\mathrm{Al}_{2} \mathrm{O}_{3}$ & $\mathrm{Fe}_{2} \mathrm{O}_{3}$ & MgO & MnO & $\mathrm{CaO}$ & $\mathrm{TiO}_{2}$ & $\mathrm{Na}_{2} \mathrm{O}$ & $\mathrm{K}_{2} \mathrm{O}$ & Total & Age (Ma) \\
\hline \multicolumn{12}{|c|}{ Tuffs of Blind Spring Valley (continued) } \\
\hline \multicolumn{12}{|c|}{ Thick, coarse bed; Pit 5 (north side) } \\
\hline TTC-17 & 77.8 & 12.7 & 0.55 & 0.05 & 0.10 & 0.33 & 0.07 & 3.74 & 4.69 & 93.97 & $2.165 \pm 0.007$ \\
\hline TTC-16 & 77.8 & 12.6 & 0.59 & 0.04 & 0.11 & 0.34 & 0.06 & 3.73 & 4.76 & 94.01 & $2.184 \pm 0.007$ \\
\hline \multicolumn{12}{|c|}{ Mostly thick, coarse airfall beds, interbedded with reworked tephra, debris flows or mud flows; Pit 6} \\
\hline TTC-22 & 77.8 & 12.6 & 0.59 & 0.04 & 0.05 & 0.34 & 0.06 & 3.73 & 4.78 & 94.8 & $2.191 \pm 0.017$ \\
\hline TTC-21 & 77.7 & 12.6 & 0.60 & 0.05 & 0.07 & 0.32 & 0.06 & 3.33 & 5.32 & 94.6 & $2.187 \pm 0.007$ \\
\hline TTC-20 & 77.7 & 12.6 & 0.58 & 0.05 & 0.06 & 0.31 & 0.05 & 3.38 & 5.29 & 95.8 & $2.176 \pm 0.008$ \\
\hline TTC-19 (1) & 77.4 & 12.6 & 0.59 & 0.05 & 0.07 & 0.32 & 0.06 & 3.85 & 5.04 & 92.7 & $2.177 \pm 0.008$ \\
\hline TTC-19 (2) & 77.5 & 12.5 & 0.59 & 0.05 & 0.07 & 0.33 & 0.06 & 3.91 & 4.89 & 93.2 & nd \\
\hline \multicolumn{12}{|c|}{ Lowermost bed of tuffs of Blind Spring Valley, reworked pumice tephra in debris flows or mudflows; Pit 6} \\
\hline TTC-25 & 77.9 & 12.5 & 0.56 & 0.03 & 0.06 & 0.31 & 0.06 & 3.58 & 4.99 & 95.0 & $2.219 \pm 0.006$ \\
\hline \multicolumn{12}{|c|}{ Tuffs of Benton Hot Spring } \\
\hline \multicolumn{12}{|c|}{ Lowermost airfall tephra, in arkosic mudflow deposits, below tuffs of Blind Spring Valley, above basalt; Pit 6} \\
\hline TTC-26A & 76.1 & 13.4 & 0.77 & 0.09 & 0.05 & 0.64 & 0.07 & 3.46 & 5.41 & 95.5 & $2.808 \pm 0.023$ \\
\hline TTC-26B & 76.0 & 13.4 & 0.77 & 0.09 & 0.06 & 0.63 & 0.07 & 3.68 & 5.30 & 95.12 & nd \\
\hline \multicolumn{12}{|c|}{ Natural glass standard used as monitor (electron-microprobe analysis) } \\
\hline $\begin{array}{l}\text { RLS } 132 \\
(\mathrm{n}=18)\end{array}$ & 75.4 & 11.3 & $2.12^{1}$ & 0.06 & 0.16 & 0.11 & 0.19 & 4.9 & 4.4 & 98.6 & \\
\hline $\pm 1 \sigma:$ & 0.1 & 0.2 & 0.04 & 0.01 & 0.01 & 0.01 & 0.01 & 0.1 & 0.1 & & \\
\hline$\%$ б: & 0.2 & 1.4 & 1.9 & 17 & 6.3 & 9 & 5.3 & 2.7 & 1.4 & & \\
\hline \multicolumn{12}{|c|}{ Natural glass standard used as monitor (wet-chemical analysis) } \\
\hline RLS 132 & 75.7 & 11.4 & $2.12^{1}$ & 0.05 & 0.15 & 0.12 & 0.21 & 5.3 & 4.5 & 99.6 & \\
\hline
\end{tabular}

${ }^{1}$ Iron reported as $\mathrm{FeO}$ for the standard. 
silicic tephra samples (Sarna-Wojcicki and Davis, 1991): Sc, Mn, Fe, Zn, Rb, Cs, Ba, La, Ce, Nd, Sm, Eu, Tb, Dy, Yt, Lu, Hf, Ta, Th, and U. Small but systematic differences in analytical results were observed among laboratories and between successive sets of analyses, as determined on replicate analyses of sample splits submitted with each set. Corrections for these differences were made using regression analyses of replicate sample sets.

\section{Methods of Data Evaluation}

Analytical data on the chemical composition of volcanic glasses of tephra layers obtained in this study were first evaluated using the similarity coefficient of Borchardt and others (1972), and Borchardt (1974). The similarity coefficient is used as a guide to select a pool of candidate samples that are further evaluated in terms of the chemical and geological criteria for the closeness of a match. We used a computer program that compares any single sample with all previously analyzed samples for those elements that are considered the most reliable in chemical identification of tephra layers and that allow us to distinguish most clearly between tephra layers of similar composition (Sarna-Wojcicki and others, 1984; Sarna-Wojcicki and Davis, 1991). The program output lists the tephra samples that match most closely to the sample that is being evaluated for the specified set of elements, and these samples are ranked in order of the value of the similarity coefficient. The highest-ranking samples represent a pool of candidates for further evaluation for correlation. Selected samples and sample groups were also compared using cluster analysis (R-mode and Q-mode), with dendrograms (Parks, 1970, and XLSTAT software program).

The best matches from the initial comparison were run again using other element combinations, to evaluate the effects of possible post-depositional cation exchange and alteration. For example, one run will include the alkalies, while a second will not. Minor elements, such as $\mathrm{Mg}, \mathrm{Mn}$, and $\mathrm{Ti}$, may be included in subsequent runs in various combinations if present in sufficient concentrations, to narrow the field of potentially correlative samples. The closest candidates were also run through the program to see if the rankings persisted in reverse comparisons ("knowns" against "unknowns"). The remaining pool of candidate samples was evaluated with regard to other criteria: independent age data, stratigraphic data, stratigraphic sequence relative to other tephra layers, and petrographic characteristics. For a more complete and detailed discussion of field criteria, petrographic characteristics, mineralogy, chemical analysis of glass, and data evaluation methods used in this report, see Sarna-Wojcicki and Davis (1991) and Sarna-Wojcicki (2000).

\section{Stratigraphic Section at Cowan Pumice Mine-Results of Age Analysis}

Tephra layers of the tuff of Blind Spring Valley are exposed in several pumice pits that are scattered over an area of about $1.5 \mathrm{~km}^{2}$ in the lower part of the western slope of the valley. The pits were excavated for commercial exploitation of the pumice. Exposures in 6 of these pits were examined in detail, measured, and sampled. A topographic transect was measured between the several quarry pits (fig. 3) and the tephra layers projected onto two cross-sections (fig. 4). A complication in deciphering the stratigraphic sequence in the pits is introduced by one or more normal faults that offset the sequence. Further complications are the low and variable dips of the units $\left(\sim 2^{\mathrm{O}}\right.$ to $\left.\sim 12^{\mathrm{O}}\right)$, which are difficult to measure, the possible presence of undetected faults in intervening areas where the layers are not exposed, and possible inset relationships of younger into older units. Using a combination of the observed stratigraphic relationships in the several pits, the topographic survey, projections onto cross-sections, the glass chemistry of the tephra layers, and their isotopic ages, we derived a composite, though partly inferred, sequence for the tephra layers exposed in the quarry pits.

The thickest, most continuous section in this area is observed at pit 6 (figs. 5-8), and this section is used as the main reference for tying together the stratigraphy in the other pits (1-5)(figs. 3, 4). At and near pit 6, all three of the dated units, the tuffs of Benton Hot Springs, the tuffs of Blind Spring Valley, and the lower tuffs of Glass Mountain, as well as the basalt that underlies the entire section, are exposed.

\section{Stratigraphic Section in and Below Pit 6}

\section{Basal Basalt Flows}

The section exposed at Pit 6 of the Cowan Pumice Mine (figs. 3-8), about $25 \mathrm{~m}$ thick, is underlain $250 \mathrm{~m}$ to the west by basalt flows that are undated at this locality but are presumed to be between 4.5 and 2.6 Ma on the basis of dates by Gilbert and others (1968) and Krauskop and Bateman (1977) on similar basalts. The basalt at this locality must be older than $\sim 2.8 \mathrm{Ma}$, the age of the oldest tephra bed in the section above the basalt (see below). An age of 3.3 Ma was obtained on replicate analyses of whole-rock olivine basalts sampled in the same range of hills (Benton Range), several kilometers to the north of the study area, by Dalrymple and Hirooka (1965). The age of this latter basalt is compatible with the chronology we present here.

\section{Basal Arkosic Mudflows and the Tuff of Benton Hot Springs}

The basalt near Pit 6 is overlain by at least $5.5 \mathrm{~m}$ of arkosic mudflow deposits containing granitic and basaltic clasts; these are barren of any clasts of silicic flow rocks or of tephra. The basal arkosic unit is overlain by another arkosic mudflow unit consisting of several flows that contain abundant, rounded pumice lapilli and an $\sim 0.5$-m-thick tephra layer in the middle of the set. The basal $20 \mathrm{~cm}$ of this tephra layer 


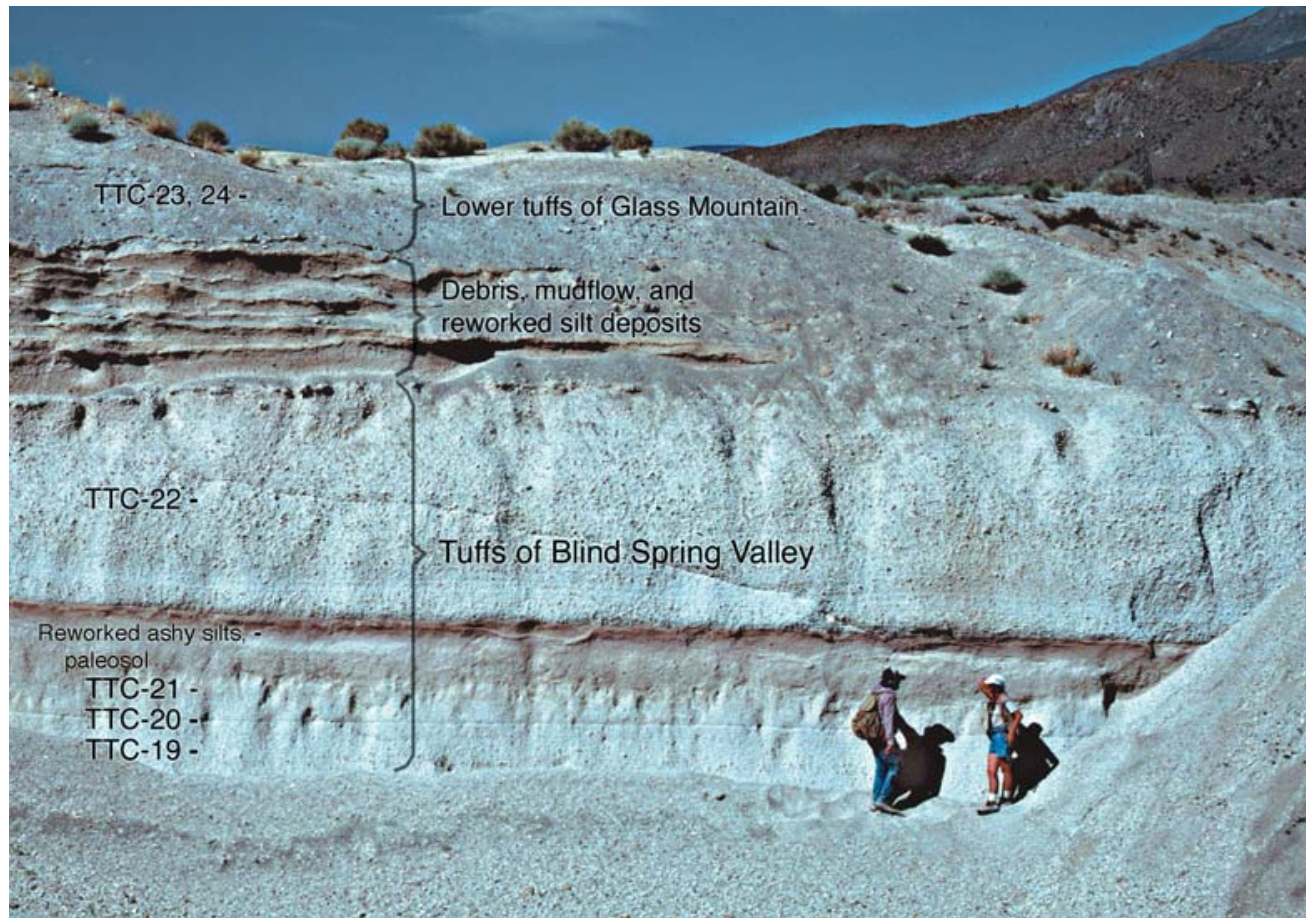

Figure 5. Tuffs of Blind Spring Valley and lower tuffs of Glass Mountain exposed in Pit 6, Cowan Pumice Mine, Blind Spring Valley, California. View is to east. See figures 2 and 3 for location of Cowan Pumice Mine and figures 3 and 4 for location of Pit 6 and cross-section. See figure 6 for a view of this section looking north, which shows the tephra layers of Glass Mountain in the upper part of this section, and figure 7 for a stratigraphic description of this exposure.

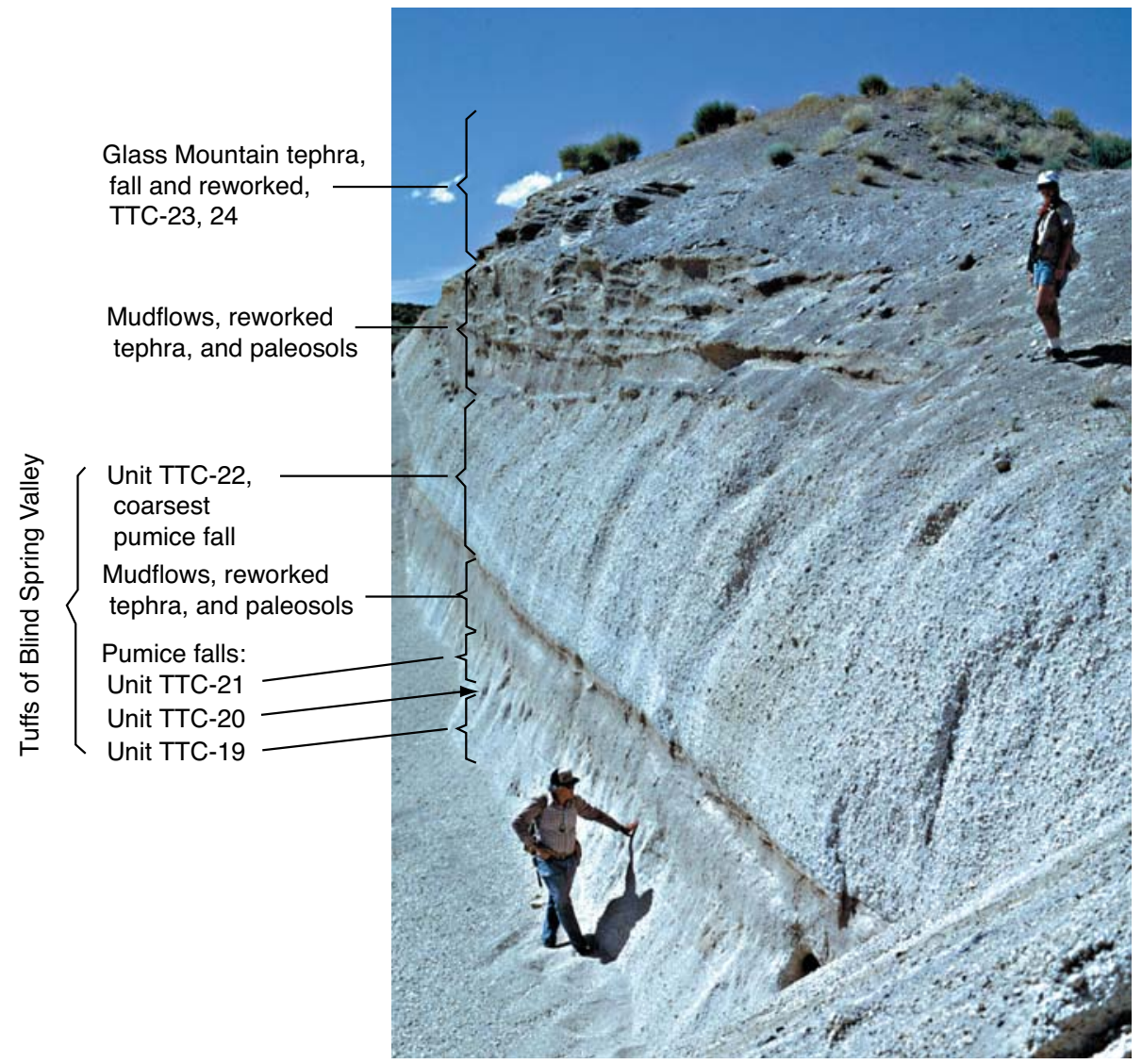

Figure 6. Pit 6 at Cowan Pumice Mine, Blind Spring Valley, Calif. Same section as shown in figure 5 , except view is to the north. The coarsest unit here, Unit TTC-22, is also probably the most widely dispersed, and is likely to correlate with distal localities in Beaver Basin, Utah (fig. 20 ), and in the Ventura Basin of southwestern California. This view shows well the channeled top of unit TTC-22 and the upper part of the section containing the Glass Mountain tephra (see fig. 8). 


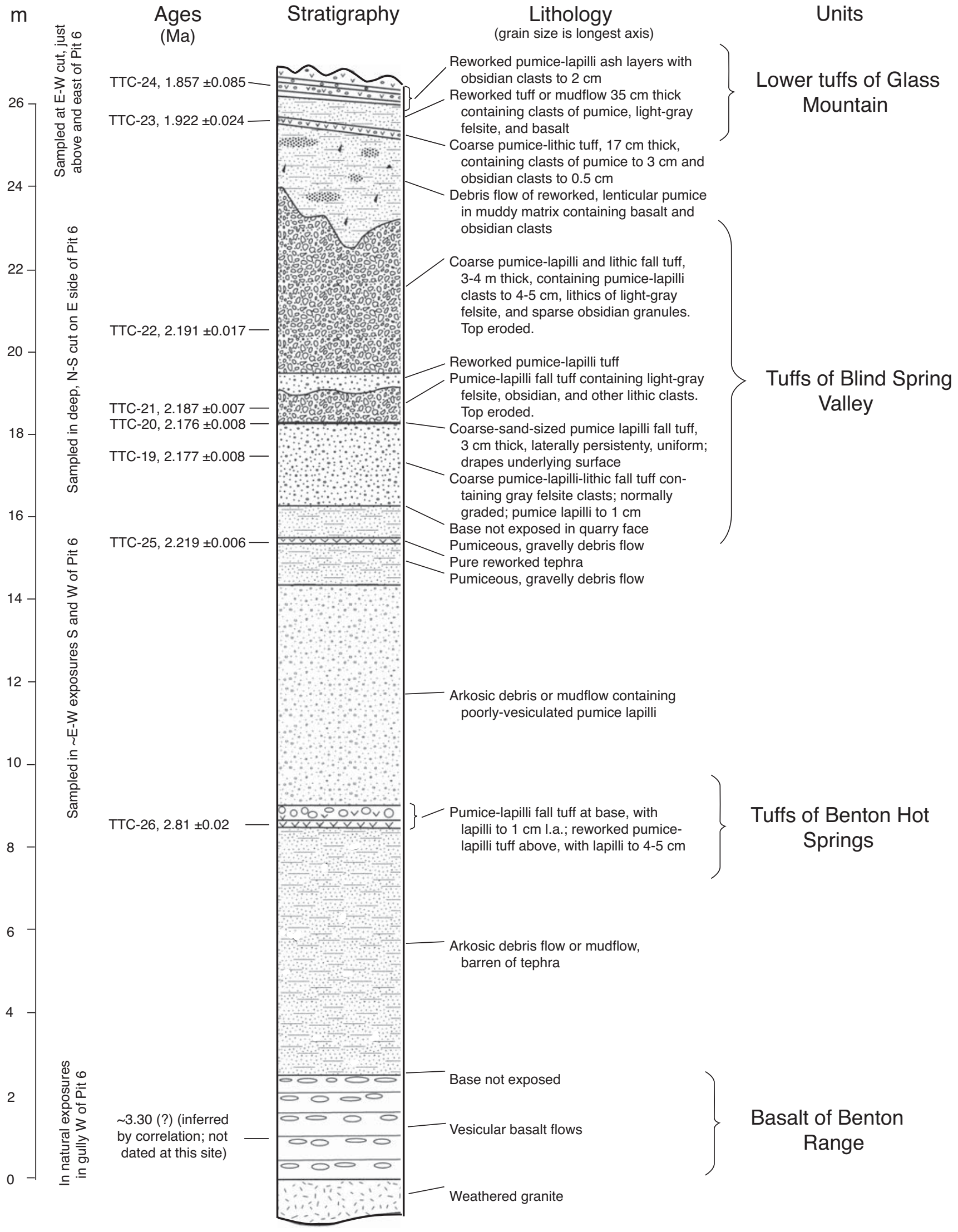

Figure 7. Stratigraphy of section in Pit 6, Cowan Pumice Mine, Blind Spring Valley, Calif. 
is well-bedded and well-sorted airfall ash, containing poorly vesiculated pumice lapilli as large as $1-2 \mathrm{~cm}$ in diameter (layers TTC-26A, B). The upper, reworked $30 \mathrm{~cm}$ of this unit contains pumice clasts as large as 4 to $5 \mathrm{~cm}$ in diameter. The layering of this unit is obscured in places by krotovinas (filled animal burrows).

Unlike the tuff of Blind Spring Valley higher in this section, the pumice in the basal tephra layer (TTC-26A, B), here informally named the tuff of Benton Hot Springs, contains mostly plagioclase feldspar but no sanidine, and the glass shards contain less $\mathrm{SiO}_{2}$ and $\mathrm{MnO}$, but more $\mathrm{Al}_{2} \mathrm{O}_{3}, \mathrm{Fe}_{2} \mathrm{O}_{3}$, $\mathrm{MgO}, \mathrm{CaO}$, and $\mathrm{K}_{2} \mathrm{O}$ than the tephra layers of the tuffs of Blind Spring Valley (table 1). This tephra layer also differs in petrographic characteristics from rhyolitic lavas and tephra layers erupted from Glass Mountain. It contains (1) dominantly tight, poorly vesiculated pumices with spherical to spindle-shaped vesicles and comagmatic biotite and magnetite, (2) abundant lithic fragments of volcanic porphyry with feldspar, biotite, and hornblende phenocrysts, and (3) free euhedral crystals and fragments of plagioclase, quartz, green hornblende, biotite, magnetite, and rare allanite. We obtained an age of $2.81 \pm 0.02 \mathrm{Ma}$ on this unit, on plagioclase feldspar grains (table 1 ). This age is older than any previously reported on tephra or lava flows of Glass Mountain (Gilbert and others, 1968; Bailey and others, 1976; Metz and Mahood, 1985; Izett and others, 1988), and at first it was suspected that this age was too old because of contamination with detrital grains (Sarna-Wojcicki and Pringle, 1992). Examination of the data of 10 separate analyses of this sample, however (appendix 1), indicates that the ages are internally consistent and that they probably reflect the true age of this unit. Despite chemical and petrographic differences from tephra layers of the tuff of Blind Spring Valley and tuffs of Glass Mountain, the tuff of Benton Hot Springs bears a "family resemblance" to tephra layers erupted from the Glass Mountain source area and related eruptive sources in the southwestern part of Nevada.

Above the 0.5-m-thick tephra bed is a 5.3-m-thick mudflow containing abundant rounded pumice lapilli in a mudstone matrix. The arkosic debris flows, the 0.5-m-thick tephra bed, and the overlying pumiceous mudflow (fig. 7), are very similar to the "stream gravels near Benton Hot Springs" (Qsg) described by Krauskopf and Bateman (1977) and may very well be the same unit.

\section{Tuffs of Blind Spring Valley}

Above the basal arkosic mudflows, and separated from them by a sharp, planar contact, is another 2-m-thick unit of mudflows, containing abundant, rounded pumice lapilli, and a 20-cm-thick, rather pure, reworked tephra layer, with coarseto medium-grained pumice lapilli (layer TTC-25) in its middle part. The sample of this tephra layer contains (1) vitreous and silky, silvery pumice lapilli with tubular vesicles or capillaries, (2) abundant angular fragments of light-gray felsite and porphyry (rhyolite?) with biotite, quartz, and sanidine phenocrysts, and occasionally, biotite, and (3) mineral grains or frag- ments of sanidine and some cloudy white plagioclase, quartz (some with glass coating), euhedral biotite, and magnetite. Some hornblende is present; one grain was observed to have glass adhering. Some brown glass shards are present, together with small spherical obsidian cores charged with microlites. The chemical composition of glass shards and the mineral content of this layer are very similar to those of the tuffs of Blind Spring Valley found higher in the section (table 1). Sanidine feldspar separated from this layer yielded a weighted mean age (using the inverse of the variance) of $2.219 \pm 0.006$ Ma. This age is close to, but older than, the oldest ages obtained on rhyolite flows of Glass Mountain, $2.13 \mathrm{Ma}$ (Metz and Mahood, 1985).

Above the mudlow unit containing tephra layer TTC-25 is an interval, 6.6-7.7 $\mathrm{m}$ thick, of several coarse and fine airfall tephra layers, with one $\sim 0.6$-m-thick layer of reworked tephra, that together represent the main part of the eruptive episode of the tuffs of Blind Spring Valley at this site (figs. 5, 6, 7). All airfall tephra layers in this interval, including a thin, $3-\mathrm{cm}$, finer grained one, were sampled to evaluate the possibility that finer grained, thin tephra layers may represent the fining edges of major tephra lobes that were transported from the eruptive source in directions other than toward the Cowan Pumice Mine.

The lowermost of the coarse tephra layers in this interval is a 1.9-m-thick airfall tephra layer (TTC-19; figs. 5, 6, 7) containing mostly drawn-out pumice lapilli as much as $1-2 \mathrm{~cm}$ in diameter, with straight or tubular capillaries. This layer also contains angular lithic fragments of light-gray felsite, limonite-stained, poorly vesiculated pumice and felsite, and bipyramidal quartz, sanidine, biotite, and ilmenite. Some grains of all these minerals have glass coats. This mineralogy is typical of all the tuffs of Blind Spring Valley higher in the section at this locality. Rare grains of hornblende with adhering glass, or encased in glass shards, are also present, but these look frayed, rounded, or embayed, and may be accidental or comagmatic crystals that had crystallized earlier and then been partially resorbed prior to eruption.

Next upwards is a 3-cm-thick, finer-grained tephra layer (TTC-20; figs. 5, 6, 7) that drapes over small irregularities in the top of the underlying layer and maintains a remarkably constant thickness. It is very well sorted, normally graded, and undoubtedly of airfall origin. It contains mostly fine- to coarse-sand-size silky, silvery pumice lapilli with near-parallel alinement of elongate, capillary-like vesicles. Its mineralogy is the same as that of the underlying TTC-19, except that it contains fresh, pretty, euhedral crystals of ilmenite and distorted, lathlike crystals of comagmatic brown biotite.

Above this 3-cm-thick layer is a 1.2-m-thick tephra layer, airfall in the lower half, reworked in the upper half (TTC-21; figs. 5, 6, 7). The upper half of the unit fills undulations in the topography of the underlying tephra layers, thinning and thickening laterally. This unit contains pumice lapilli that are similar in appearance and size to those of TTC-19. Some of the pumices contain very small, euhedral crystals or fragments of biotite, but the layer is otherwise similar in mineralogy to the other underlying layers of the Tuffs of Blind Spring Valley. 
Next upward, resting on a sharp contact, is the thickest, coarsest tephra layer of the sequence (TTC-22), 3.5 to $4.6 \mathrm{~m}$ thick, composed of angular pumice clasts as much as 4 to 5 $\mathrm{cm}$ in diameter. Other than its coarse grain size, this airfall layer is similar in all respects to the layers beneath. This layer is inferred by Izett and others (1988) to correlate with their Taylor Canyon-C; its coarse grain size and thickness suggest it is likely to be found in far distal localities, particularly toward the east (for example, in Beaver Basin, Utah).

Laser-fusion ${ }^{40} \mathrm{Ar} /{ }^{39} \mathrm{Ar}$ ages on the $\sim 7$-m-thick tephra interval of dominantly airfall tephra layers, proceeding upward in the section, are: $2.177 \pm 0.008 \mathrm{Ma}$ (TTC-19); $2.176 \pm 0.008$ $\mathrm{Ma}$ (TTC-20); $2.187 \pm 0.007 \mathrm{Ma}$ (TTC-21); and 2.191 \pm 0.017 Ma (TTC-22, the thickest, coarsest layer)(table 1; appendix 1).

\section{Lower Tuffs of Glass Mountain}

Above the thickest, coarsest layer of the tuff of Blind Spring Valley (TTC-22), there is as much as $4 \mathrm{~m}$ of reworked and airfall tephra (figs. 5-8). The base of this part of the section consists of a mudflow 2-2.5 m thick containing lenses of reworked, rounded pumice and some large basalt clasts (perhaps derived from the underlying basalt) and smaller obsidian clasts. This unit is channeled into the top of the underlying tephra layer and swells and pinches out laterally. The mudflow is overlain by a sequence of thinly bedded, cross-bedded, reworked, and airfall tephra layers that we refer to here as the lower tuffs of Glass Mountain (figs. 7,8 ), on the basis of stratigraphy, chemical composition of the volcanic glass (which differs from that of the tuffs of Blind Spring Valley), and laser-fusion $\mathrm{Ar} / \mathrm{Ar}$ and conventional $\mathrm{K}-\mathrm{Ar}$ ages.

Above the mudflow is a 17-cm-thick, well-sorted, coarse pumice-lithic airfall tuff, containing pumice clasts as large as 3 $\mathrm{cm}$ in diameter, and obsidian clasts as large as $0.5 \mathrm{~cm}$ in diameter (layer TTC-23). This layer contains, in addition to the preponderant pumice lapilli, abundant lithic fragments of light-gray felsite, obsidian clasts, and brown glass shards, as well as sanidine (some intergrown with ilmenite), free, abundant quartz (some as euhedral, bipyramidal crystals), biotite, ilmenite, magnetite, and rare zircon. This unit is overlain by a 35-cm-thick reworked ash or ashy mudflow, consisting of pumice lapilli and lithic fragments, including basalt, in a fine, tuffaceous muddy matrix. All overlying tephra layers at this site thicken to the east and are buttressed against the 35-cm-thick bed. These uppermost layers consist of reworked, cross-bedded pumice lapilli and lithic clasts, including abundant, coarse obsidian (layer TTC-24).

Within the section at Pit 6, macroscopic obsidian clasts appear first in the lower half of the tuff of Blind Spring Valley, within layer TTC-21, where they appear as sparse sandand granule-size clasts. Obsidian clasts increase in size and abundance upward in the section, and are coarsest and most abundant in the lower tuffs of Glass Mountain, at the level of layers TTC-23 and -24 .

Four ages were obtained on the set of lower tuffs of Glass Mountain at Pit 6. Sanidine feldspar grains from layer TTC-23 yielded ${ }^{40} \mathrm{Ar} /{ }^{\beta 9} \mathrm{Ar}$ ages of $1.936 \pm 0.030 \mathrm{Ma}$ and $1.898 \pm 0.039$ $\mathrm{Ma}$, for a weighted average of $1.922 \pm 0.024 \mathrm{Ma}$. Two conven-

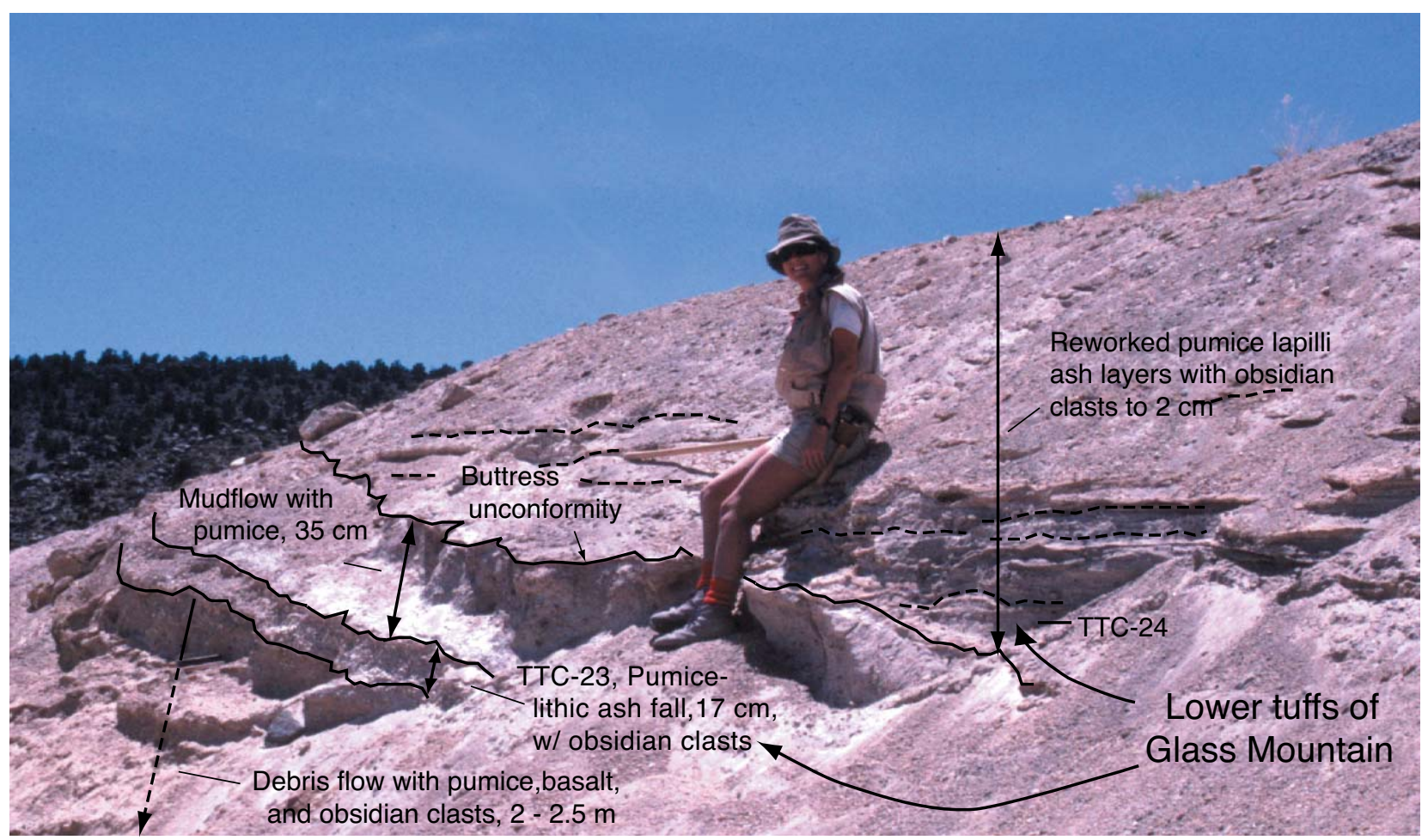

Figure 8. Upper part of section at Pit 6, Cowan Pumice Mine. View to north. Airfall pumice and ash, and reworked pumice lapilli ash layers of Glass Mountain, with direct ages of 1.92 $\pm 0.02 \mathrm{Ma}$ on TTC-23 (average of two laser-fusion Ar-Ar dates on sanidine), and 1.86 $\pm 0.09 \mathrm{Ma}$ on TTC-24 (average of two K-Ar dates on obsidian clasts, J.K. Nakata, written commun., 1987). 
tional K-Ar analyses on obsidian clasts collected from two levels in layer TTC-24, gave ages of $1.799 \pm 0.050 \mathrm{Ma}$ and $1.981 \pm 0.073 \mathrm{Ma}$, for a weighted average age of $1.857 \pm 0.085$ Ma (table 1).

\section{Tephra Layers Exposed in Pits 1 Through 5}

\section{The Bishop Ash}

The uppermost part of the section at the Cowan Pumice Mine, exposed in Pit 1, about $1.35 \mathrm{~km}$ to the southeast of Pit 6 , is about 70-100 m stratigraphically above the level of the lower tuffs of Glass Mountain and the tuffs of Blind Spring Valley (figs. 3, 4). In Pit 1, a single very coarse tephra layer at least $3.7 \mathrm{~m}$ thick (the base is not exposed) contains pumice clasts as much as $15 \mathrm{~cm}$ in diameter (TTC-7). The chemical composition of the pumice glass and the mineralogy of this unit are different from the tuffs of Blind Spring Valley; they are more similar to the tuffs of Glass Mountain and to the much younger Bishop ash bed (Sarna-Wojcicki and others, 1984)(table 1). A fisson-track age on zircon crystals separated from this unit yielded an age of $0.75 \pm 0.05 \mathrm{Ma}$ (Meyer and others, 1991), and sanidine feldspar grains from the same pumice clasts analyzed by laser-fusion ${ }^{40} \mathrm{Ar} /{ }^{39} \mathrm{Ar}$ yielded an age of 0.757 $\pm 0.004 \mathrm{Ma}$ (Sarna-Wojcicki and others, 2000). Both ages are in good agreement with other ages of the Bishop Tuff and air-fall ash bed obtained by Sarna-Wojcicki and Pringle (1992), and Sarna-Wojcicki and others (2000). The volcanic glass of this pumice bed contains somewhat higher concentrations of iron, magnesium, calcium, and titanium than the basal Bishop air-fall pumice and the overlying Bishop ash flow tuff at the south end of the Volcanic Tableland (Chalk Cliffs) north of Bishop, and also higher concentrations of these elements than distal samples of the Bishop ash bed. Consequently, we suspect that this layer may have been erupted during later stages of the Bishop eruption (Wilson and Hildreth, 1997). Nevertheless, in light of its age, this coarse tephra layer (TTC7) is undoubtedly the Bishop Tuff.

The intervening section between Pits 1 and 6 is not exposed (figs 3,4). Thus, we do not know whether tephra from younger eruptions of Glass Mountain (in the age range of $~ 1.8$ to $0.76 \mathrm{Ma}$; Sarna-Wojcicki and others, 1980; 1984; Izett, 1981; Metz and Mahood, 1985; Izett and others, 1988) is present above the lower tuffs of Glass Mountain (TTC-24), and below the Bishop Tuff (TTC-7). Tephra layers within this interval, however, have been dated at other sites, for example at the Chalk Cliffs (see below).

\section{Tuffs of Blind Spring Valley}

Tephra layers from exposures in Pits 2 through 5 were analyzed regardless of thickness or grain size, to test the possibility that fine-grained layers might be marginal deposits from major eruptions, rather than products of small eruptions. Pit 5 has the thickest and most varied stratigraphy of pits $2-5$. The section at the south side of Pit 5 is $\sim 5 \mathrm{~m}$ thick (figs. 9, 10) and consists of a coarse, thick layer at the base, with pumice lapilli as large as $1 \mathrm{~cm}$ in diameter (TTC-6, -8). This unit may be even thicker, but its base is not exposed. Above this are about $1.2 \mathrm{~m}$ of well bedded, intercalated fine to coarse tephra layers (TTC-9 through 12) and well-sorted, tuffaceous silt and fine sand. These sediments may be in part lacustrine. Above these beds is a coarse, massive to poorly bedded air-fall tephra layer $\sim 2.8 \mathrm{~m}$ thick, containing pumice lapilli as large as $2-3 \mathrm{~cm}$ in diameter (TTC-4, -13). In Pit 2 (fig. 11), Pits 3 and 4, and the north side of Pit 5, only one or two tephra layers are exposed; these appear to be coeval with layers in Pit 6, on the basis of projections in the sections, isotopic ages, and chemistry of the volcanic glass.

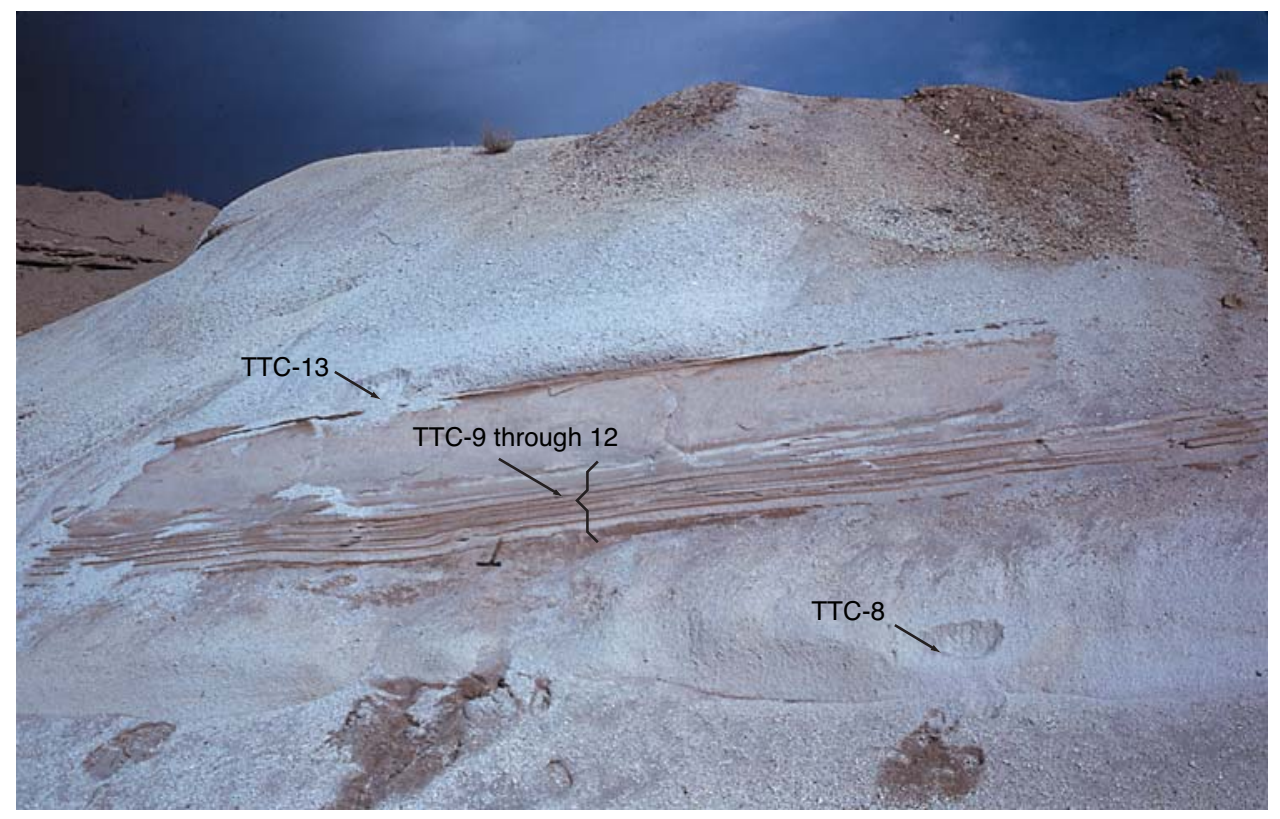

Figure 9. Two thick, coarse pumice fall tuffs of Blind Spring Valley at south wall of Pit 5 , Cowan Pumice Mine (samples TTC-8 and -13), separated by several thin, well-bedded, fine-grained tephra (samples TTC-9 through -12), and a 0.5 -m-thick tan tuffaceous silt above the latter. See figure 10 for a stratigraphic description of this section. The fine-grained, middle part of this section may be lacustrine. 


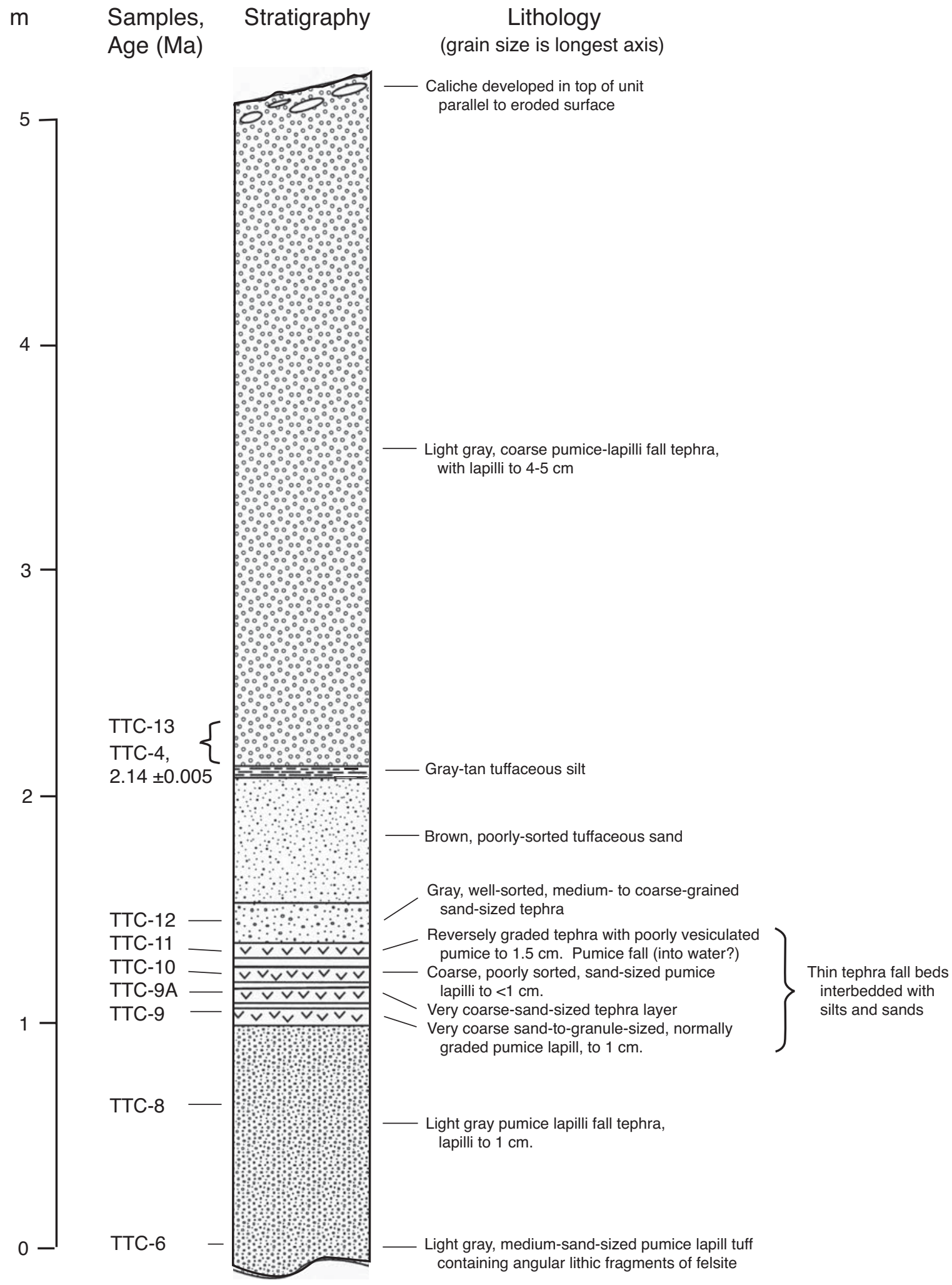

Figure 10. Stratigraphy of tuffs of Blind Spring Valley at Pit 5, Cowan Pumice Mine, Blind Spring Valley, California. 
Although tephra layers in Pits 2 through 5 are chemically and petrographically very similar to the tuffs of Blind Spring Valley in Pit 6 (table 1), glass shards of the layers in Pits 2-5 have slightly higher contents of $\mathrm{MnO}$ and, on the average, slightly higher $\mathrm{CaO}$ than the tuffs of Blind Spring Valley in Pit 6 (table 1). Results of EDXRF show little difference between the tuffs of Blind Spring Valley in Pit 6 and Pits 2-5. The laser-fusion ${ }^{40} \mathrm{Ar} /{ }^{39} \mathrm{Ar}$ ages on sanidines from samples in Pits 2 through 5 range from 2.184 to $2.135 \mathrm{Ma}$. The older part of this range overlaps with the younger ages of the tuffs of Blind Spring Valley in Pit 6, but most of the ages of units in Pits 2 through 5 are slightly younger (table 1; appendix 1).

\section{Isotopic Ages of the Upper Glass Mountain Tephra Layers at Chalk Cliffs, at the South End of the Volcanic Tableland}

At the Cowan Pumice Mine there are no exposures of upper Glass Mountain tephra layers in the age range of $\sim 1.5$ to $\sim 0.8 \mathrm{Ma}$, above the lower tuffs of Glass Mountain and below the Bishop air-fall pumice. Cross sections (fig. 4) indicate that about 65-70 $\mathrm{m}$ of section are present above the lower tuffs of Glass Mountain, below the Bishop airfall pumice, but lack of exposures within the intervening $1.4 \mathrm{~km}$ and deep cover by younger alluvium prevented us from examining these sediments.

Several of the upper Glass Mountain tephra layers in the age range of $\sim 1.0 \mathrm{Ma}$ to $\sim 0.8 \mathrm{Ma}$ are present, however, beneath the Bishop Tuff and airfall pumice at the south end of the Volcanic Tableland, along the Owens River, north of Bishop, Calif. (Chalk Cliffs; Sarna-Wojcicki and others, 1980; 1984; 1997; Izett, 1981; Izett and others, 1988)(figs. 2, 12). The chemical compositions of the volcanic glasses of these tephra layers (table 2) are similar both to that of the Bishop ash and to those of the lower tephra layers of Glass Mountain (tables 1-4), although the calcium appears to be generally lower in the lower layers and higher in the higher layers. A new laser-fusion ${ }^{40} \mathrm{Ar}{ }^{39} \mathrm{Ar}$ age on the lowermost of three tephra layers exposed at this locality is $1.13 \pm 0.19 \mathrm{Ma}$ (BT-15; sanidine)(appendix 1; fig. 12). This sample may be contaminated with older detrital sanidine or xenocrysts, because the mean square of wighted deviates (MSWD), a ratio of the total error of the experiment divided by

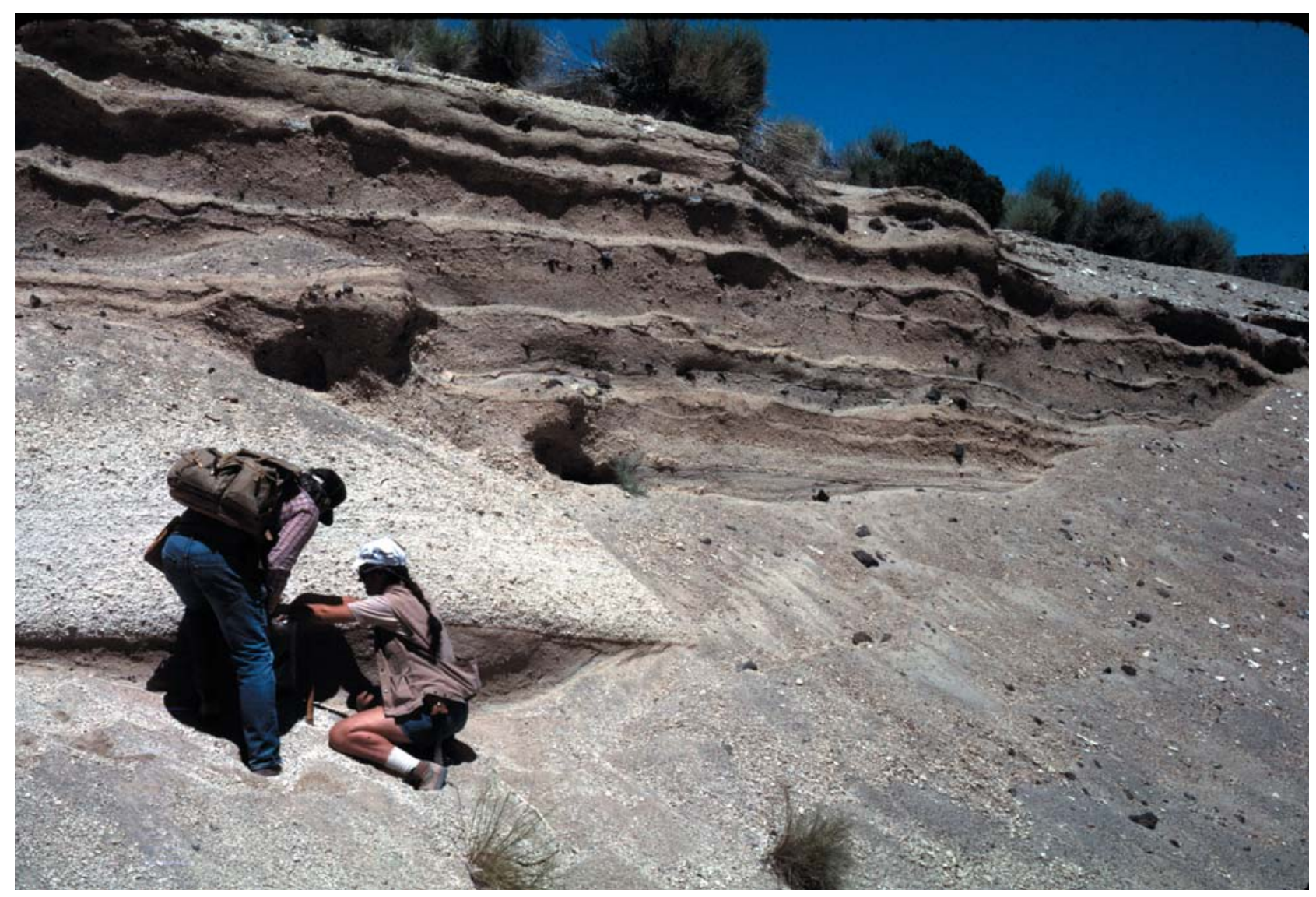

Figure 11. One of the tuffs of Blind Spring Valley, in Pit 2, is the thick, white pumice-fall unit in middle left. Sample TTC-18, from base of this unit, is dated $2.16 \pm 0.02 \mathrm{Ma}$ by laser-fusion $\mathrm{Ar} / \mathrm{Ar}$ on sanidine. This unit is probably the same as TTC-22 in Pit 6, dated 2.19 $\pm 0.02 \mathrm{Ma}$ (fig. 5). As at TTC-22, this layer overlies reworked eolian tephra and paleosols and underlies the thick section of debris flows and reworked tephra containing basalt clasts. The top of the pumice unit is eroded and uneven, with the overlying debris flows and reworked tephra layers filling-in the uneven topography. Also see figures 4-7. 
Table 2. Electron-microprobe analysis of glass of the Bishop Tuff and Bishop airfall pumice (0.774 Ma), compared with the younger set of tephra layers of Glass Mountain ( 0.8 to $1.2 \mathrm{Ma})$.

[Values given are weight-percent oxide, recalculated to 100 percent fluid-free basis. Original oxide totals before recalculation $(*)$ are given to indicate approximate degree of hydration of volcanic glass. About 15 or more individual glass shards were analyzed for each sample. Electron-microprobe chemical analyses by C. E. Meyer (1977 to 1996). Compositions of volcanic glass from tephra layers of the Tuff of Taylor Canyon, both pumice and obsidian, from the type locality in Taylor Canyon, are also given for comparison (samples TCTL-4 and -5).]

\begin{tabular}{|c|c|c|c|c|c|c|c|c|c|c|}
\hline Sample & $\mathrm{SiO}_{2}$ & $\mathrm{Al}_{2} \mathrm{O}_{3}$ & $\mathrm{Fe}_{2} \mathrm{O}_{3}$ & MgO & MnO & $\mathrm{CaO}$ & $\mathrm{TiO}_{2}$ & $\mathrm{Na}_{2} \mathrm{O}$ & $\mathrm{K}_{2} \mathrm{O}$ & Total* $^{*}$ \\
\hline \multicolumn{11}{|c|}{ Bishop Tuff, fine-grained base of ash-flow, Insulating Aggregates Quarry, southeast end of Volcanic Tableland, south of Long Valley, Calif. } \\
\hline BT-7A & 77.63 & 12.48 & 0.74 & 0.03 & 0.05 & 0.42 & 0.07 & 3.87 & 4.71 & ND \\
\hline BT-7B & 77.57 & 12.48 & 0.73 & 0.02 & 0.05 & 0.43 & 0.07 & 3.88 & 4.78 & ND \\
\hline BT-7C & 77.54 & 12.60 & 0.75 & 0.03 & 0.03 & 0.45 & 0.05 & 3.86 & 4.66 & 94.64 \\
\hline \multicolumn{11}{|c|}{ Bishop Tuff, basal pumice fall beneath ash flow, (same locality as BT-7, above), } \\
\hline BT-8A & 77.75 & 12.48 & 0.73 & 0.03 & 0.05 & 0.44 & 0.05 & 3.82 & 4.65 & 94.07 \\
\hline BT-8B & 77.40 & 12.73 & 0.72 & 0.04 & 0.04 & 0.45 & 0.06 & 3.34 & 5.22 & 94.11 \\
\hline BT-8C & 77.48 & 12.68 & 0.71 & 0.03 & 0.02 & 0.45 & 0.06 & 3.85 & 4.72 & 94.27 \\
\hline \multicolumn{11}{|c|}{ Bishop Tuff, basal pumice fall beneath ash-flow, southwest end of Volcanic Tableland, south of Long Valley, Calif. } \\
\hline BT-11D2 & 77.17 & 13.13 & 0.76 & 0.02 & 0.04 & 0.42 & 0.05 & 3.73 & 4.66 & 93.91 \\
\hline BT-11D1 & 77.47 & 12.75 & 0.74 & 0.03 & 0.04 & 0.41 & 0.04 & 3.76 & 4.76 & 93.81 \\
\hline BT-11C2 & 77.57 & 12.71 & 0.68 & 0.03 & 0.05 & 0.40 & 0.06 & 3.78 & 4.71 & 94.09 \\
\hline BT-11C1 & 77.71 & 12.59 & 0.72 & 0.03 & 0.04 & 0.42 & 0.06 & 3.67 & 4.76 & 93.94 \\
\hline BT-11B2, & 77.71 & 12.71 & 0.74 & 0.03 & 0.04 & 0.39 & 0.05 & 3.67 & 4.65 & 94.13 \\
\hline BT-11B1 & 77.65 & 12.64 & 0.71 & 0.03 & 0.05 & 0.39 & 0.06 & 3.64 & 4.83 & 94.34 \\
\hline BT-11A2 & 77.80 & 12.55 & 0.71 & 0.03 & 0.04 & 0.40 & 0.06 & 3.80 & 4.61 & 93.84 \\
\hline BT-11A1 & 77.55 & 12.72 & 0.69 & 0.03 & 0.04 & 0.43 & 0.06 & 3.69 & 4.78 & 94.37 \\
\hline \multicolumn{11}{|c|}{ Bishop Tuff, air-fall layer at top of section, Cowan Pumice Mine, east of Long Valley, Calif. } \\
\hline TTC-7 & 77.30 & 12.65 & 0.82 & 0.09 & 0.04 & 0.54 & 0.09 & 3.71 & 4.76 & 93.94 \\
\hline \multicolumn{11}{|c|}{ Ash of Glass Mountain (D), water-deposited, south-central end of Volcanic Tableland, south of Long Valley, Calif. } \\
\hline BT-2A & 77.27 & 12.90 & 0.79 & 0.03 & 0.03 & 0.43 & 0.06 & 3.68 & 4.81 & 95.12 \\
\hline BT-2B & 77.95 & 12.25 & 0.71 & 0.03 & 0.05 & 0.41 & 0.06 & 3.53 & 5.00 & 95.36 \\
\hline BT-2C & 77.64 & 12.67 & 0.74 & 0.03 & 0.03 & 0.43 & 0.07 & 3.66 & 4.73 & 94.76 \\
\hline \multicolumn{11}{|c|}{ Ash of Glass Mountain (E), air-fall, beneath and same locality as BT-2 } \\
\hline BT-14A & 77.21 & 12.78 & 0.75 & 0.03 & 0.04 & 0.43 & 0.06 & 3.77 & 4.92 & ND \\
\hline BT-14B & 77.41 & 12.77 & 0.77 & 0.04 & 0.04 & 0.45 & 0.07 & 3.53 & 4.92 & 94.39 \\
\hline \multicolumn{11}{|c|}{ Pumice of Glass Mountain (F), reworked, beneath and same locality as BT-14A, B } \\
\hline BT-15 & 77.18 & 12.77 & 0.77 & 0.04 & 0.03 & 0.46 & 0.06 & 3.85 & 4.85 & 94.90 \\
\hline
\end{tabular}


the error expected from analytical errors alone, is quite large (appendix 1). An age of $0.88 \pm 0.07$ Ma wa obtained on the stratigraphically next higher layer (BT-16)(SEM, standard error of the mean, is used here; see appendix 1). Six ${ }^{40} \mathrm{Ar} /{ }^{\beta 9} \mathrm{Ar}$ ages on feldspars grains obtained from a layer (BT-14) that overlies both of the latter layers (fig. 12) were scattered and considerably older than the ages of BT-15 and BT-16 (appendix 3). Consequently, sample BT-14 is considered to be contaminated. BT-14 has been previously referred to as Glass Mountain ash D (SarnaWojcicki and others, 1984; Izett and others, 1988).

The chemical composition of the volcanic glass of these upper Glass Mountain tephra layers at the Chalk Cliffs locality is very similar to that of tephra layers and dome collapse breccias in the tuff of Taylor Canyon of Krauskopf and Bateman (1977) at the type locality in Taylor Canyon, north and northeast of Long Valley. Thus these two sets of tephra layers, both underlying the Bishop Tuff with small stratigraphic separation, are in all probability correlative (table 2 ).

\section{Interpretation of the Isotopic Ages at the Cowan Pumice Mine}

The age of the basal tephra layers in the sequence near Pit $6(2.81 \pm 0.023 \mathrm{Ma}$; TTC-26) precedes the oldest age of the tuffs of Blind Spring Valley by $\sim 0.6$ m.y. In light of its significantly older age and different petrographic and chemical characteristics, we attribute this tuff to a separate, earlier volcanic episode and give it the informal name of the tuff of Benton Hot Springs, named after a small town near the north end of Blind Spring Valley. The coarse grain size of the tuff of Benton Hot Springs at the Cowan Pumice Mine suggests that the volcanic source area was close by, possibly in the vicinity of Glass Mountain. However, to our knowledge, no rocks of this age are exposed at Glass Mountain; the oldest age obtained on volcanic-flow rocks from that source is $2.13 \mathrm{Ma}$ (Metz and Mahood, 1985). The 0.6m.y. interval between the eruption of this oldest tephra layer and the tuffs of Blind Spring Valley represents a hiatus in the section at the Cowan Pumice Mine locality. Multiple tephra layers with broad chemical affinities to those of the tuffs of Blind Spring Valley and the tuffs of Glass Mountain were erupted during the period between 2.8 and 2.2 Ma and are present elsewhere in the region, but not within the Cowan Pumice Mine section. They are found, for example, in the Willow Wash section south of Fish Lake Valley (fig. 1, table 4; also see below). The sharp, planar contact above the tuffs of Benton Hot Springs is likely to be an unconformity. The section exposed in the pits of the Cowan Pumice Mine, situated on the western flank of Blind Spring Valley, is a condensed section. The depositional center of the valley is to the east of the pits, and tephra units correlative with those present in the pits are buried beneath younger deposits in the center of Blind Spring Valley. For this reason, the section at the Cowan Pumice Mine is likely to contain hiatuses.

The lowermost, reworked tephra layer ascribed to the tuffs of Blind Spring Valley (TTC-25; 2.219 $\pm 0.006 \mathrm{Ma}$ ) is 
Table 3. Chemical composition, determined by electron-microprobe analysis, of volcanic glass shards from middle Pleistocene and upper Pliocene tephra layers of northeastern Fish Lake Valley, Calif.- Nev. (Emigrant Pass area and vicinity).

[Samples are arranged in stratigraphic order, with youngest at top. Values given are in weight-percent oxide, recalculated to 100 percent. Original oxide totals before recalculation are given to indicate ap-proximate degree of hydration of volcanic glass. About 15 individual glass shards were analyzed for each sample. C. E. Meyer, analyst.]

\begin{tabular}{|c|c|c|c|c|c|c|c|c|c|c|}
\hline Sample & $\mathrm{SiO}_{2}$ & $\mathrm{Al}_{2} \mathrm{O}_{3}$ & $\mathrm{Fe}_{2} \mathrm{O}_{3}$ & MgO & $\mathrm{MnO}$ & $\mathrm{CaO}$ & $\mathrm{TiO}_{2}$ & $\mathrm{Na}_{2} \mathrm{O}$ & $\mathrm{K}_{2} \mathrm{O}$ & Total \\
\hline \multicolumn{11}{|c|}{ Bishop ash bed: thick, coarse, reworked ash and tuff in nearshore sands of pluvial lake in Fish Lake Valley above alluvial gravels } \\
\hline FLV-163-CS & 77.6 & 12.9 & 0.79 & 0.02 & 0.05 & 0.41 & 0.06 & 3.5 & 4.8 & 93.4 \\
\hline \multicolumn{11}{|c|}{ Tuffs of Glass Mountain (undifferentiated): fine-grained, thin-bedded tephra layers in alluvial gravels } \\
\hline FLV-162-CS & 77.4 & 12.9 & 0.77 & 0.03 & 0.07 & 0.46 & 0.07 & 3.4 & 5.0 & 93.5 \\
\hline FLV-161-CS & 77.5 & 12.8 & 0.71 & 0.03 & 0.06 & 0.45 & 0.06 & 3.5 & 5.0 & 94.0 \\
\hline FLV-160-CS & 77.4 & 12.8 & 0.73 & 0.01 & 0.06 & 0.50 & 0.07 & $3.5^{*}$ & 4.9 & 93.8 \\
\hline \multicolumn{11}{|c|}{ Lower (?) tuffs of Glass Mountain: fine-grained, lenticular tephra layers in alluvial gravels } \\
\hline FLV-177-CS & 77.1 & 12.5 & 0.70 & 0.03 & 0.03 & 0.40 & 0.05 & 2.8 & 5.8 & 94.2 \\
\hline FLV-178-CS & 77.7 & 12.5 & 0.70 & 0.03 & 0.03 & 0.40 & 0.05 & 3.1 & 5.5 & 95.0 \\
\hline \multicolumn{11}{|c|}{ Tuffs of Emigrant Pass: fine-grained, lenticular tephra layers in alluvial gravels } \\
\hline FLV-190-EP & 77.6 & 12.4 & 0.65 & 0.05 & 0.10 & 0.29 & 0.07 & $3.3^{*}$ & 5.6 & 95.1 \\
\hline FLV-189-EP & 77.6 & 12.4 & 0.65 & 0.04 & 0.12 & 0.28 & 0.05 & 3.4 & 5.6 & 95.3 \\
\hline \multicolumn{11}{|c|}{ Huckleberry Ridge ash bed: thick, fine-grained bed at transition between alluvial gravels (above) and lake beds (below) } \\
\hline FLV-179-EP & 76.6 & 12.1 & 1.72 & 0.01 & 0.04 & 0.59 & 0.11 & 2.8 & $6.0 *$ & 93.1 \\
\hline \multicolumn{11}{|c|}{ Tuffs of Blind Spring Valley: fine- to medium-grained air-fall and reworked tephra layers intercalated with lake beds (except for FLV-184-EP, which is not correlated) } \\
\hline FLV-188-EP-A & 77.9 & 12.1 & 0.58 & 0.05 & 0.09 & 0.31 & 0.05 & $3.1^{*}$ & 5.8 & 96.1 \\
\hline FLV-187-EP & 77.6 & 12.3 & 0.59 & 0.05 & 0.08 & 0.36 & 0.08 & $3.0^{*}$ & 5.9 & 95.2 \\
\hline FLV-186-EP-A & 77.1 & 12.6 & 0.60 & 0.06 & 0.09 & 0.31 & 0.07 & $3.2^{*}$ & 5.9 & 93.5 \\
\hline FLV-185-EP & 77.3 & 12.7 & 0.57 & 0.05 & 0.09 & 0.33 & 0.07 & $3.0^{*}$ & 6.0 & 93.3 \\
\hline FLV-184-EP & 77.3 & 12.8 & 0.58 & 0.06 & 0.04 & 0.78 & 0.09 & 2.7 & 5.6 & 92.9 \\
\hline FLV-183-EP & 77.2 & 12.7 & 0.56 & 0.05 & 0.11 & 0.31 & 0.07 & $3.2 *$ & 5.8 & 93.7 \\
\hline FLV-182-EP-A & 76.7 & 13.1 & 0.57 & 0.04 & 0.11 & 0.31 & 0.09 & $3.1^{*}$ & 6.0 & 92.1 \\
\hline FLV-181-EP-A & 77.0 & 12.9 & 0.59 & 0.05 & 0.11 & 0.32 & 0.10 & 3.0 & 5.9 & 93.0 \\
\hline FLV-180-EP & 77.1 & 12.9 & 0.59 & 0.04 & 0.11 & 0.32 & 0.10 & 3.0 & 5.8 & 93.0 \\
\hline
\end{tabular}


Table 4. Electron-microprobe analyses of volcanic glass shards from middle Pleistocene and upper Pliocene tephra layers of the Willow Wash area, south of Fish Lake Valley, Calif.- Nev.

[Values given are in weight-percent oxide, recalculated to 100 percent. Original oxide totals before recalculation are given to indicate approximate degree of hydration of volcanic glass. About 15 or more individual glass shards were analyzed for each sample. Undet. - magnetic polarity undeterminable. C. E. Meyer, electron-microprobe analyst.]

\begin{tabular}{|c|c|c|c|c|c|c|c|c|c|c|c|}
\hline Sample & $\mathrm{SiO}_{2}$ & $\mathrm{Al}_{2} \mathrm{O}_{3}$ & $\mathrm{Fe}_{2} \mathrm{O}_{3}$ & MgO & $\mathrm{MnO}$ & $\mathrm{CaO}$ & $\mathrm{TiO}_{2}$ & $\mathrm{Na}_{2} \mathrm{O}$ & $\mathrm{K}_{2} \mathrm{O}$ & Total & Polarity \\
\hline \multicolumn{12}{|c|}{ Badlands section } \\
\hline \multicolumn{12}{|c|}{ Tuffs of Glass Mountain } \\
\hline FLV-126-WW & 77.8 & 12.1 & 0.78 & 0.05 & 0.03 & 0.45 & 0.07 & 3.7 & 5.0 & 93.4 & Normal \\
\hline FLV-125-WW & 78.0 & 12.1 & 0.76 & 0.05 & 0.04 & 0.39 & 0.05 & 3.9 & 4.8 & 93.6 & Normal \\
\hline FLV-124-WW & 77.6 & 12.6 & 0.76 & 0.02 & 0.05 & 0.34 & 0.06 & 4.0 & 4.6 & 94.9 & Normal \\
\hline \multicolumn{12}{|c|}{ Lower tuffs of Glass Mountain } \\
\hline FLV-48-WW & 77.4 & 12.8 & 0.71 & 0.04 & 0.06 & 0.32 & 0.06 & 3.8 & 4.8 & 95.2 & Normal \\
\hline FLV-47-WW & 78.0 & 12.3 & 0.72 & 0.03 & 0.07 & 0.31 & 0.04 & 3.8 & 4.7 & 90.6 & Normal \\
\hline \multicolumn{12}{|c|}{ Tuffs of Emigrant Pass } \\
\hline FLV-46-WW & 77.9 & 12.4 & 0.68 & 0.02 & 0.08 & 0.30 & 0.07 & 3.8 & 4.7 & 91.3 & Reversed \\
\hline FLV-45-WW & 78.0 & 12.3 & 0.67 & 0.02 & 0.10 & 0.29 & 0.07 & 3.9 & 4.7 & 91.2 & Reversed \\
\hline FLV-44-WW & 77.8 & 12.6 & 0.64 & 0.04 & 0.10 & 0.29 & 0.05 & 3.9 & 4.5 & 91.3 & Reversed \\
\hline \multicolumn{12}{|c|}{ Tuffs of Blind Spring Valley } \\
\hline FLV-43-WW & 78.0 & 12.3 & 0.56 & 0.03 & 0.08 & 0.32 & 0.06 & 3.8 & 4.8 & 91.9 & Normal \\
\hline FLV-42-WW & 77.9 & 12.3 & 0.61 & 0.04 & 0.07 & 0.36 & 0.06 & 3.6 & 5.1 & 91.5 & Reversed \\
\hline FLV-123-WW & 77.5 & 12.6 & 0.59 & 0.03 & 0.08 & 0.35 & 0.08 & 3.8 & 5.0 & 94.7 & Reversed \\
\hline FLV-122-WW & 77.5 & 12.6 & 0.59 & 0.02 & 0.08 & 0.34 & 0.07 & 3.8 & 5.0 & 94.7 & Reversed \\
\hline FLV-41-WW & 77.7 & 12.7 & 0.55 & 0.04 & 0.11 & 0.31 & 0.09 & 3.6 & 5.0 & 93.5 & Reversed \\
\hline FLV-40-WW & 78.0 & 12.6 & 0.55 & 0.04 & 0.10 & 0.34 & 0.09 & 3.8 & 4.6 & 93.6 & Reversed \\
\hline FLV-39-WW & 77.6 & 12.6 & 0.53 & 0.06 & 0.09 & 0.35 & 0.10 & 2.8 & 5.9 & 93.2 & Reversed \\
\hline \multicolumn{12}{|c|}{ Tuffs of the Badlands (upper set) } \\
\hline FLV-38-WW & 79.2 & 12.7 & 0.54 & 0.05 & 0.08 & 0.42 & 0.10 & 2.2 & 4.8 & 92.2 & Reversed \\
\hline FLV-138-WW & 76.8 & 13.0 & 0.56 & 0.04 & 0.09 & 0.42 & 0.09 & 2.7 & 6.4 & 93.5 & Reversed \\
\hline FLV-37-WW & 77.7 & 12.7 & 0.55 & 0.05 & 0.08 & 0.40 & 0.09 & 3.2 & 5.3 & 93.9 & Reversed \\
\hline \multicolumn{12}{|c|}{ Tuffs of the Badlands (lower set) } \\
\hline FLV-36-WW & 77.5 & 12.8 & 0.58 & 0.05 & 0.09 & 0.43 & 0.11 & 3.7 & 4.8 & 94.0 & Normal \\
\hline FLV-35-WW & 77.6 & 12.7 & 0.60 & 0.06 & 0.07 & 0.49 & 0.10 & 3.8 & 4.7 & 94.1 & Normal \\
\hline FLV-121-WW & 77.6 & 13.0 & 0.65 & 0.04 & 0.06 & 0.57 & 0.07 & 2.9 & 6.2 & 94.4 & Normal \\
\hline
\end{tabular}


Table 4. Electron-microprobe analyses of volcanic glass shards from middle Pleistocene and upper Pliocene tephra layers of the Willow Wash area, south of Fish Lake Valley, Calif.- Nev.-Continued

[Values given are in weight-percent oxide, recalculated to 100 percent. Original oxide totals before recalculation are given to indicate approximate degree of hydration of volcanic glass. About 15 or more individual glass shards were analyzed for each sample. Undet. - magnetic polarity undeterminable. C. E. Meyer, electron-microprobe analyst.]

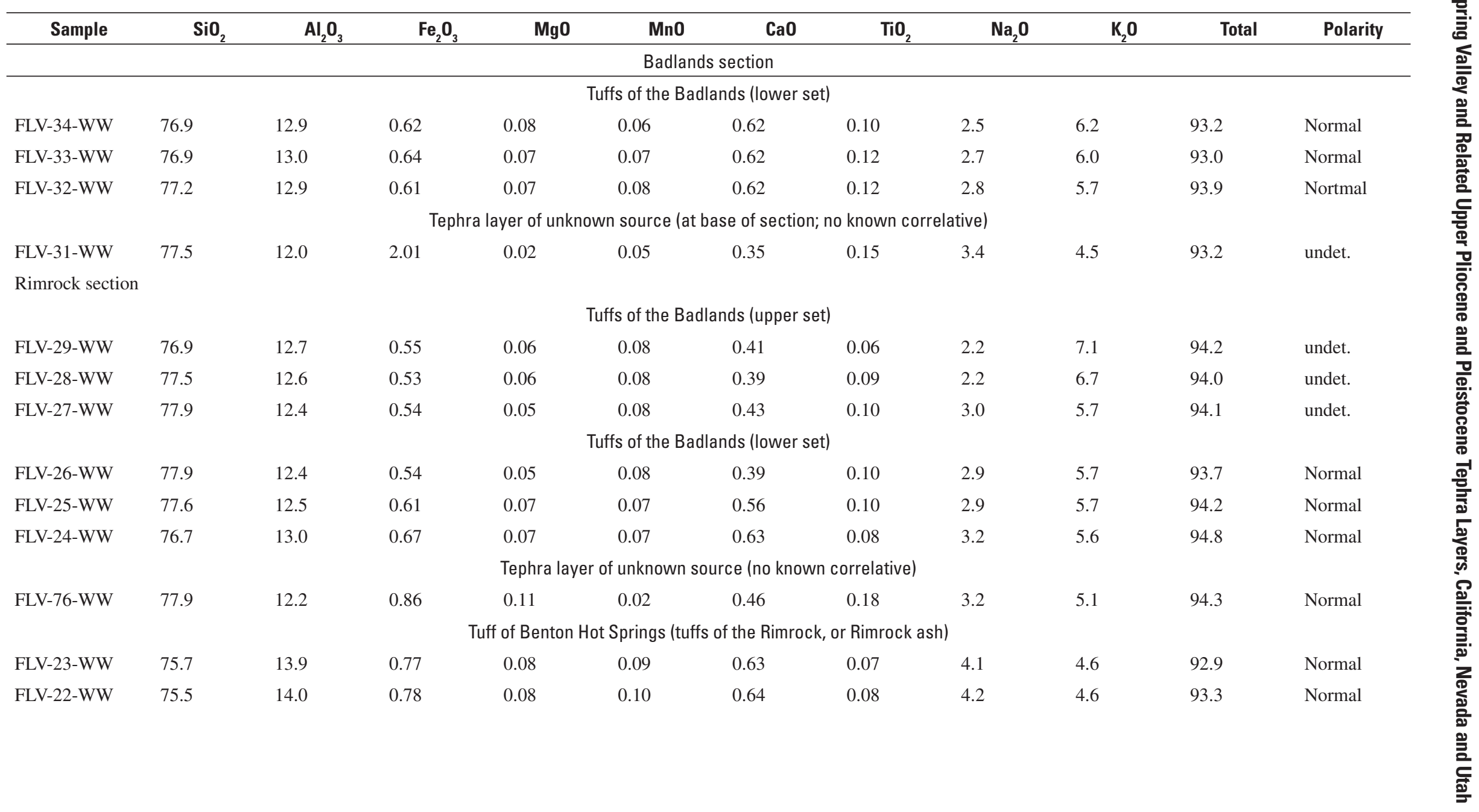


somewhat older than the oldest ages on the main sequence of overlying coarse tuffs of Blind Spring Valley in Pit 6 (TTC-19 through TTC-22; 2.190-2.176 Ma; fig. 5, table 1). Thus, a dormant period of $\sim 30 \mathrm{k} . \mathrm{y}$. may have intervened between initial activity and the main eruptive episode. Again, the section at the Cowan Pumice Mine contains hiatuses, and any tephra that was erupted during this $\sim 30-\mathrm{k} . \mathrm{y}$. period could have been eroded or not deposited at this site (see below).

The four ages of the tuffs of Blind Spring Valley at Pit 6 (TTC-19 through TTC-22) form a tight cluster in time and are not significantly different within analytical error (appendix 1; fig. 6). In fact, three of the ages (TTC-20, -21, and -22, dated $2.176 \pm 0.008,2.187 \pm 0.007$, and $2.191 \pm 0.017 \mathrm{Ma}$, respectively) are reversed relative to their stratigraphic positions in the section, but the age differences between them are not significant within analytical error. The ages of these four layers together form a continuum with those obtained for tephra layers in Pits 2-5 (TTC-4,- 6, -15, -16, -17, -18; table 1), and appear to represent an episode of volcanic activity from about $\sim 2.19$ to $\sim 2.14 \mathrm{Ma}$. The tephra layers below the unconformity and Glass Mountain tephra in Pit 6, however, are slightly older than the layers in Pits 2 through 5. The oldest layers in Pit 6

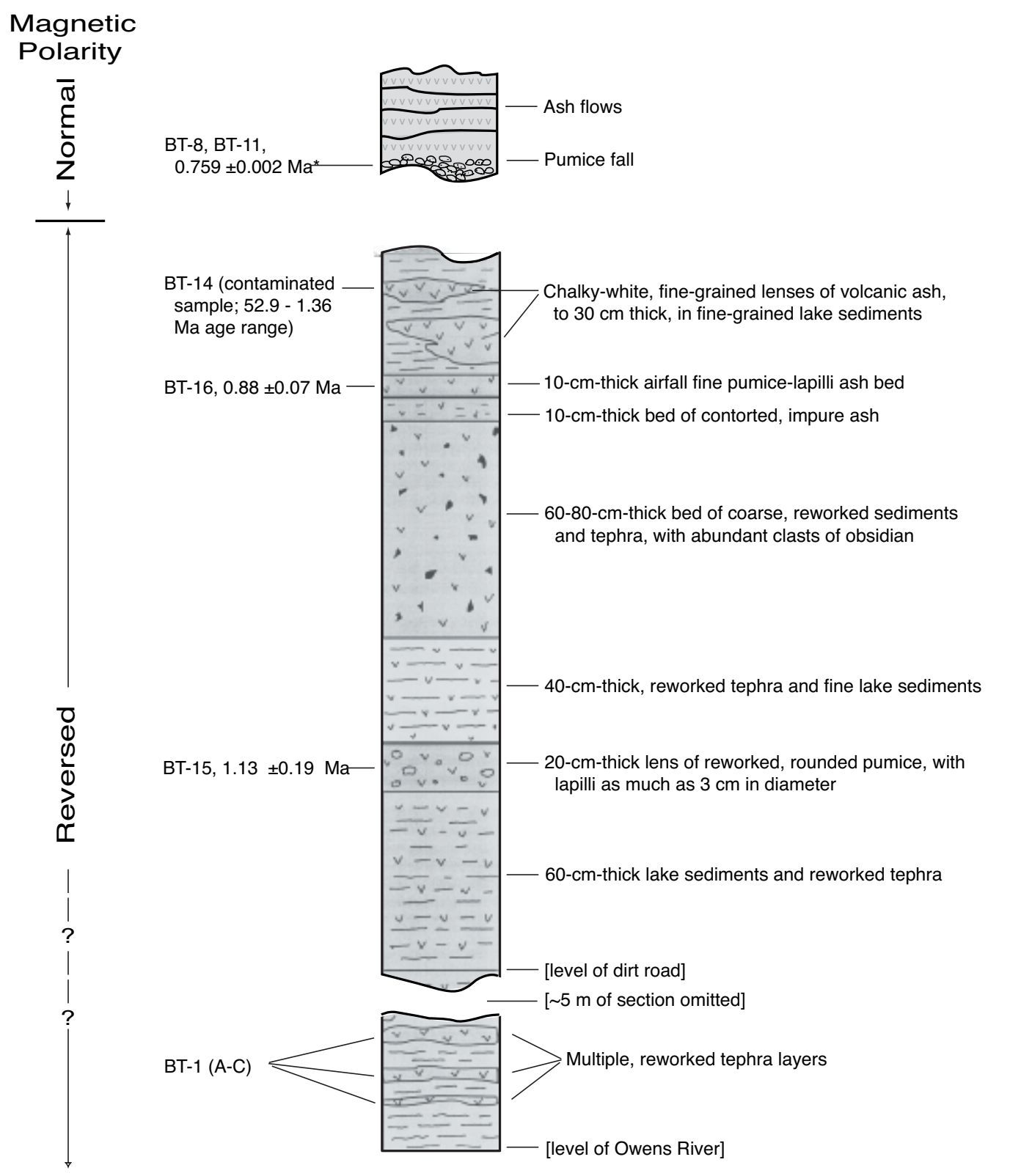

$\frac{0}{\omega}$
$\frac{0}{0}$
$\frac{0}{0}$
달

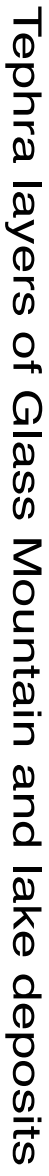

* Standard error of the mean of multiple determinations from several sites, including BT-8 and BT-11.

Figure 12. Composite stratigraphic section at Chalk Cliffs, south end of Volcanic Tableland, $11 \mathrm{~km}$ north of Bishop, Calif., showing stratigraphy and new laser-fusion ${ }^{40} \mathrm{Ar} /{ }^{39} \mathrm{Ar}$ ages of the younger tephra layers of Glass Mountain, beneath the Bishop tuff. See figure 2 for location. 
are significantly older than the oldest layers in Pits 2 through 5 , suggesting that some section of the tuffs of Blind Spring Valley may have been cut out at Pit 6, at the top of the tuffs of Blind Spring Valley, below the tuffs of Glass Mountain.
Slight differences in manganese concentration of glass shards of the tephra layers in Pit 6, as determined by the electron microprobe, are not apparent in EDXRF analysis (table 5), but may be significant. The tephra layers of the tuffs of Blind

Table 5. Energy-dispersive X-ray fluorescence analysis of volcanic glass from tephra layers.

[Charles E.Meyer, Janet L. Slate, Andrei M. Sarna-Wojcicki, and Elmira Wan, analysts, U.S. Geological Survey, Menlo Park. Concentrations in weight percent for the oxides, and in parts per million atomic weight for the remaining elements. Analyses were done on a Kevex energy-dispersive X-ray fluorescence spectrometer.]

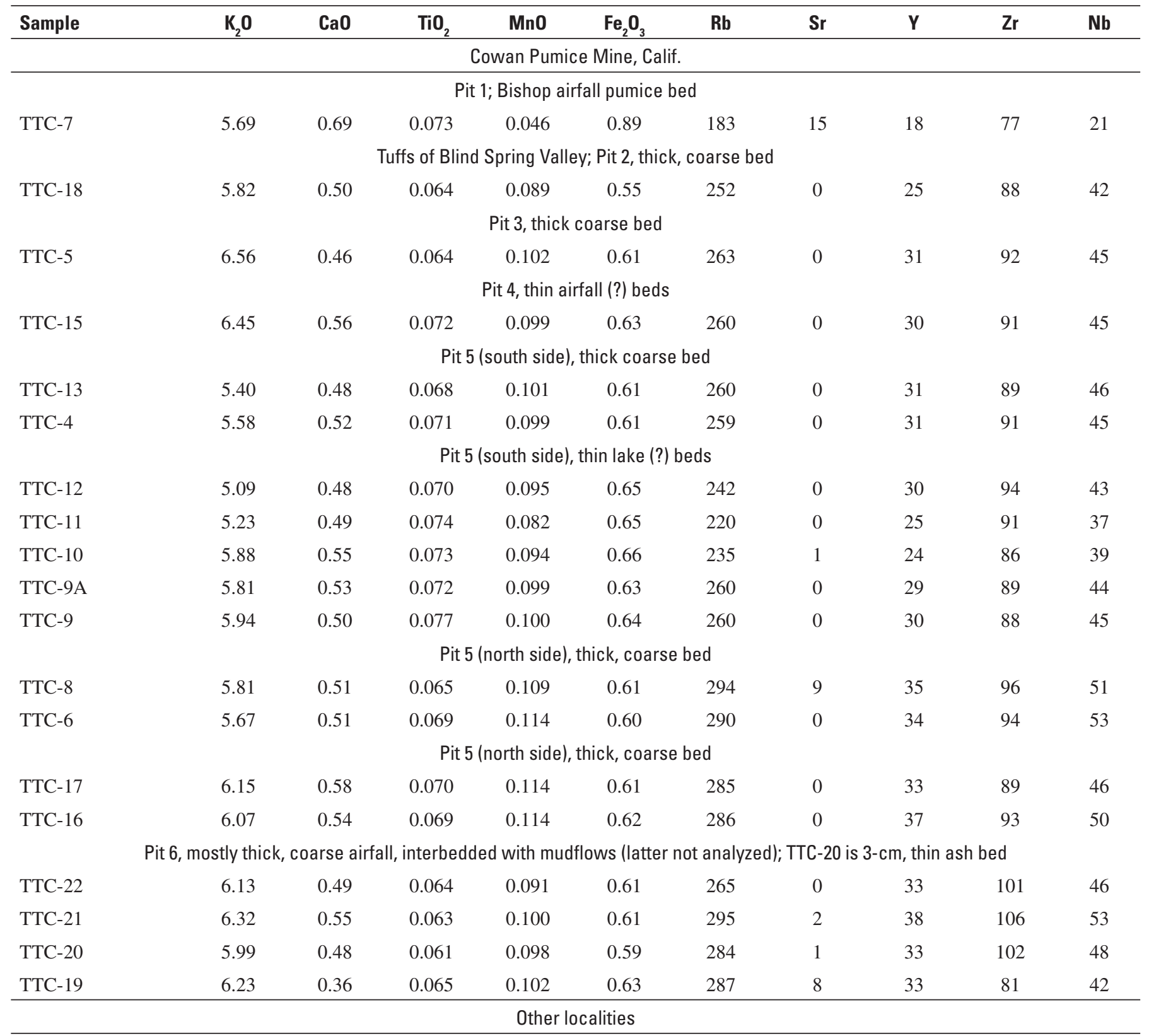

Tephra layers in the Waucoba Lake Beds of Hopper (1947), Westgard Road locality (tuffs of Emigrant Pass, W3A, and tuffs of Blind Spring Valley, W2A); Waucoba Road locality (tuffs of Blind Spring Valley, WAC-7 and WAC-6), Owens Valley, Calif.

$\begin{array}{lllllllllll}\text { W3A } & 5.88 & 0.50 & 0.048 & 0.100 & 0.70 & 326 & 0 & 45 & 105 & 60 \\ \text { W2A } & 5.22 & 0.46 & 0.070 & 0.108 & 0.61 & 293 & 10 & 37 & 93 & 52 \\ \text { WAC-7 } & 5.65 & 0.43 & 0.047 & 0.095 & 0.68 & 330 & 1 & 45 & 106 & 60 \\ \text { WAC-6 } & 5.62 & 0.47 & 0.066 & 0.092 & 0.62 & 273 & 1 & 37 & 105 & 50\end{array}$


Table 5. Energy-dispersive X-ray fluorescence analysis of volcanic glass from tephra layers.-Continued

[Charles E.Meyer, Janet L. Slate, Andrei M. Sarna-Wojcicki, and Elmira Wan, analysts, U.S. Geological Survey, Menlo Park. Concentrations in weight percent for the oxides, and in parts per million atomic weight for the remaining elements. Analyses were done on a Kevex energy-dispersive X-ray fluorescence spectrometer.]

\begin{tabular}{|c|c|c|c|c|c|c|c|c|c|c|}
\hline Sample & $\mathrm{K}_{2} \mathrm{O}$ & $\mathrm{CaO}$ & $\mathrm{TiO}_{2}$ & MnO & $\mathrm{Fe}_{2} \mathrm{O}_{3}$ & $\mathbf{R b}$ & $\mathrm{Sr}$ & $\mathbf{Y}$ & $\mathrm{Zr}$ & $\mathrm{Nb}$ \\
\hline \multicolumn{11}{|c|}{ Other localities-continued } \\
\hline \multicolumn{11}{|c|}{ Confidence Hills, Southern Death Valley, Calif., (in strat. order) } \\
\hline CHA86G9 & 5.35 & 0.54 & 0.061 & 0.044 & 0.76 & 182 & 1 & 19 & 88 & 25 \\
\hline CHA86G8 & 5.57 & 0.52 & 0.059 & 0.047 & 0.80 & 199 & 1 & 24 & 95 & 27 \\
\hline CHA86W5 & 5.44 & 0.51 & 0.056 & 0.051 & 0.78 & 200 & 0 & 22 & 89 & 29 \\
\hline \multicolumn{11}{|c|}{ Tuffs of Emigrant Pass } \\
\hline СНА86ВT3 & 5.20 & 0.48 & 0.051 & 0.105 & 0.71 & 346 & 0 & 44 & 99 & 60 \\
\hline \multicolumn{11}{|c|}{ Huckleberry Ridge ash bed } \\
\hline \multicolumn{11}{|c|}{ Manix Basin, Mojave Desert, Calif. } \\
\hline \multicolumn{11}{|c|}{ Tuffs of Emigrant Pass (?) } \\
\hline MANIX-8 & 3.50 & 0.41 & 0.048 & 0.098 & 0.71 & 325 & 0 & 49 & 108 & 61 \\
\hline MANIX-4 & 3.62 & 0.39 & 0.053 & 0.102 & 0.70 & 327 & 9 & 44 & 99 & 58 \\
\hline MANIX-7 & 3.31 & 0.40 & 0.057 & 0.102 & 0.71 & 325 & 10 & 45 & 101 & 60 \\
\hline \multicolumn{11}{|c|}{ Balcom Canyon, Ventura Basin, Southwestern Calif., } \\
\hline \multicolumn{11}{|c|}{ Tuffs of Blind Spring Valley } \\
\hline P-169Q & 4.80 & 0.46 & 0.064 & 0.111 & 0.67 & 287 & 11 & 36 & 95 & 51 \\
\hline 3. VA-2-1982 & 5.84 & 0.62 & 0.096 & 0.040 & 1.79 & 207 & 12 & 85 & 224 & 55 \\
\hline 4. CHA-86-BT-2 & 5.11 & 0.68 & 0.107 & 0.044 & 1.83 & 197 & 4 & 77 & 225 & 52 \\
\hline 5. TECO-12B & 5.25 & 0.65 & 0.111 & 0.046 & 1.91 & 201 & 16 & 83 & 251 & 53 \\
\hline 6. TECO-2 & 5.15 & 0.65 & 0.124 & 0.046 & 1.91 & 185 & 25 & 73 & 240 & 46 \\
\hline 7. TECO-1 & 5.79 & 0.69 & 0.126 & 0.046 & 1.96 & 189 & 7 & 74 & 253 & 53 \\
\hline 8. PICO-157 & 4.48 & 0.61 & 0.105 & 0.045 & 1.85 & 199 & 14 & 83 & 241 & 53 \\
\hline 9. SM-ASH-36 & 5.10 & 0.64 & 0.097 & 0.043 & 1.83 & 206 & 13 & 84 & 222 & 54 \\
\hline 10. HPA-1 & 5.06 & 0.61 & 0.103 & 0.042 & 1.80 & 203 & 17 & 86 & 229 & 56 \\
\hline 11. DSDP 36-4 & 5.42 & 0.62 & 0.119 & 0.045 & 1.88 & 203 & 19 & 84 & 247 & 58 \\
\hline Average of 11 & 5.31 & 0.65 & 0.110 & 0.044 & 1.85 & 200 & 14 & 81 & 235 & 54 \\
\hline $\pm 1 \sigma$ & 0.42 & 0.03 & 0.010 & 0.002 & 0.06 & 8 & 6 & 5 & 12 & 3 \\
\hline
\end{tabular}


Spring Valley in Pit 6 (TTC-19 through -22, and TTC-25), are otherwise not distinguished chemically from the set in Pits 2 though 5 (TTC-4 through -6 ; -8 through -13 ; and -15 through -18). The ages of this combined group, consisting of ten dates (excluding the lowermost tephra layer assigned to the tuffs of Blind Spring Valley, TTC-25), represents an age range of about 50 k.y. for the main eruptive episode of the tuffs of Blind Spring Valley. The lowermost layer having the chemical characteristics of the tuffs of Blind Spring Valley (TTC-25), but a somewhat older age, appears to be a precursor of this episode. The entire eruptive episode of the tuffs of Blind Spring Valley, then, lasted about 90 k.y. Stratigraphic evidence of significant elapsed time between eruptions is present in the section near and at Pit 6, between the lowermost layer of the tuff of Blind Spring Valley (TTC-25, 2.22 Ma) and the next highest unit, the basal tuff exposed in Pit 6 (TTC-19, 2.19 Ma). There is also stratigraphic evidence of some elapsed time between layer TTC-21 and the higher, coarsest layer TTC-22 (figs, 5, 6). The upper contact of layer 21 is eroded and overlain by ashy silts reworked by wind and water(?), with incipient soil development. The top of layer TTC-22 is also irregular and eroded and overlain by reworked pumice, ash, and mudflow deposits and wind-blown silt, with incipient soil development. These latter sediments were deposited after the deposition of the tuff of Blind Spring Valley, but before the deposition of the early tuffs of Glass Mountain.

The conventional K-Ar ages on obsidian clasts and laser-fusion ${ }^{40} \mathrm{Ar} /{ }^{39} \mathrm{Ar}$ ages on sanidine feldspar grains from the uppermost set of tephra layers at Pit 6 (TTC-23 and -24) are not significantly different from each other, within analytical error, but are significantly younger than the ages of the tuffs of Blind Spring Valley (table 1). We refer to these upper layers here as the lower tuffs of Glass Mountain, because of their similar age and glass chemical composition to tephra layers and flows erupted from Glass Mountain and their differences in composition from the tuffs of Blind Spring Valley. A weighted mean age for the four dates of the upper set of layers from Pit 6 is $1.90 \pm 0.04 \mathrm{Ma}$, with a $95 \%$ confidence interval of from 1.82 to $1.97 \mathrm{Ma}$. Some section is missing between the tuffs of Blind Spring Valley and the lower tuffs of Glass Mountain at Pit 6, as can be seen in the stratigraphy of the Emigrant Pass section at Fish Lake Valley (fig. 13; also see below). At the latter locality, the Huckleberry Ridge ash bed and the tuffs of Emigrant Pass are both present between the tuffs of Blind Spring Valley and the lower tuffs of Glass Mountain, but are absent at the Cowan Pumice Mine.

\section{Correlation of the Tuffs of Blind Spring Valley to Sites in the Region}

\section{Northeastern Fish Lake Valley}

A suite of 13 tephra layers intercalated with ancient lake beds and alluvial fan gravels are exposed in bluffs near the northeastern end of Fish Lake Valley, Nev., about $56 \mathrm{~km}$ east of the Cowan Pumice Mine (figs. 1, 13). Ten of the tephra layers are in the lower, dominantly lacustrine section of tuffaceous mudstones, siltstones, and sandstones, which provide evidence of a former lake in the now dry to marshy valley (Reheis and others, 1993). Nine of these lower tephra layers (FLV-180-EP through FLV-183-EP; FLV-185-EP through FLV-188-EP; and FLV-211-EP; table 3) are chemically and petrographically identical to the tuffs of Blind Spring Valley at the Cowan Pumice Mine (Pits 2 through 5; TTC-4 through 6; TTC-8 through 13; TTC-15 through 18; and, except for minor differences in $\mathrm{MnO}$ concentrations, TTC-19 through TTC-22 at pit 6)(table 1). The tenth tephra layer of the lower set at Fish Lake Valley (FLV-184-EP) is chemically similar to the tuffs of Blind Spring Valley, but has an anomalously higher calcium content. A correlative of this tephra layer has not been found at the Cowan Pumice Mine or elsewhere.

Stratigraphically upward in the section from the lower 10 tephra layers, there is a transitional interval of shallow-water lake beds with thin gravel beds, in turn overlain by alluvial fan gravel and poorly sorted sand beds. Within the dominantly lacustrine part of the transition interval (fig. 13), there is a 0.5-m-thick, light gray, fine-grained vitric tephra layer (FLV179-EP). The glass composition of this unit matches well with that of the Huckleberry Ridge ash bed, erupted from the Yellowstone area of Wyoming and Idaho, about 1,600 km to the northeast (Izett, 1981; Sarna-Wojcicki and others, 1980, 1984; table 3). We conclude that this tephra layer is the Huckleberry Ridge ash bed, on the basis of the chemical composition of the glass shards, glass shard morphologies, the stratigraphic position of this bed, close above the tuffs of Blind Spring Valley, and the correlated ages of the underlying tuff of Blind Spring Valley and of the overlying older tuffs of Glass Mountain.

Conventional K-Ar ages determined previously on the Huckleberry Ridge ash bed are $\sim 2.02$ to $2.00 \mathrm{Ma}$ (Christiansen and blank, 1972; Izett, 1981; Izett and Wilcox, 1982; J. D. Obradovich, written commun., 1986). In this study, we have determined an age of $2.063 \pm 0.007 \mathrm{Ma}$ on sanidine feldspar grains from a more proximal exposure of the Huckleberry Ridge ash bed in the Yellowstone source area (appendix 1). Sanidine grains present in the Huckleberry Ridge ash bed near Emigrant Pass are too fine grained to date directly. Using the somewhat older monitor value for the Tuff of Taylor Creek of Renne and others (1998), the age of the Huckleberry Ridge ash bed recalculates to $2.09 \mathrm{Ma}$.

Above the Huckleberry Ridge ash bed near Emigrant Pass, within the interbedded gravel and sand, are two lenticular tephra layers that we here refer to as the (informal) tuffs of Emigrant Pass (FLV-189-EP; FLV-190-EP). These tuffs are transitional in glass composition between the tuffs of Blind Spring Valley (below) and the lower tuffs of Glass Mountain (above). Thus, the tephra of the tuffs of Emigrant Pass was probably also erupted from the vicinity of Glass Mountain, as were those of the tuffs of Blind Spring Valley and Glass Mountain. Neither the tuffs of Emigrant Pass nor the Huckleberry Ridge ash bed have been found at the Cowan Pumice 


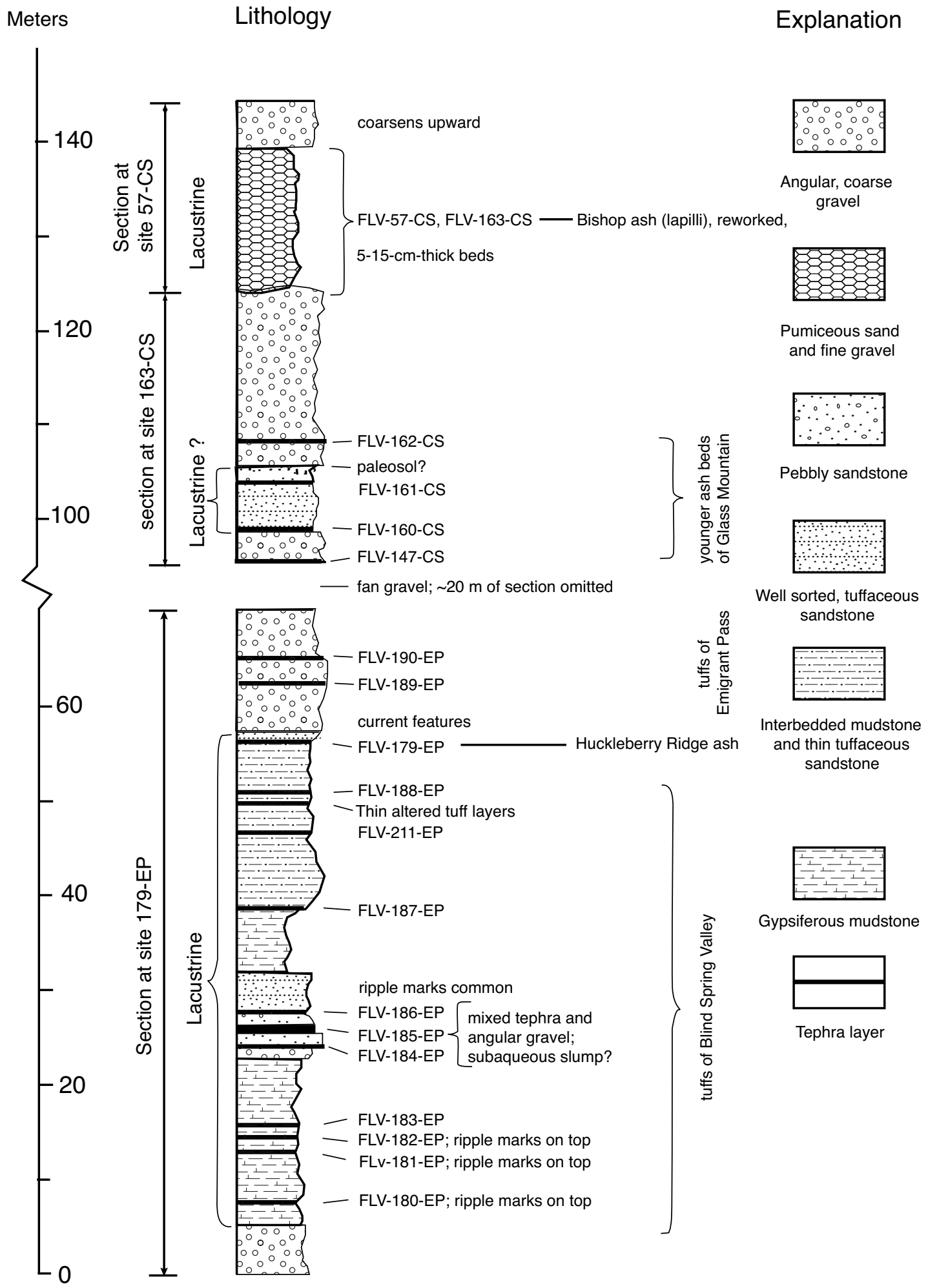

Figure 13. Stratigraphy of section near Emigrant Pass, northeast Fish Lake Valley, Nevada. Slightly modified from Reheis and others (1993). 
Mine, however. They were thus either not deposited at that site or were eroded after deposition. Stratigraphicaly higher up in the fan gravels above the tuffs of Emigrant Pass in northwestern Fish Lake Valley, south of the above-mentioned exposure, are several tephra layers that match on the basis of glass chemical composition with the tuffs of Glass Mountain (FLV-147CS; FLV-160-CS through FLV-162-CS; Reheis and others, 1991). We cannot determine on the basis of glass composition whether these layers belong to the lower or upper tuffs of Glass Mountain. Their age is only loosely constrained between 0.8 and $1.96 \mathrm{Ma}$ on that basis, but magnetostratigraphy in the Willow Wash section to the south helps to constrain the ages of some of these layers more closely (see below). Above the tuffs of Glass Mountain, interbedded with alluvial fan gravels, is a 15 -m-thick nearshore or beach deposit containing multiple thin layers of reworked Bishop pumice and ash (FLV-57-CS and FLV-163-CS)(Reheis and others, 1991; 1993).

\section{Willow Wash Section}

The Willow Wash section is south of Fish Lake Valley, in east-central California, about $80 \mathrm{~km}$ to the southeast of the Cowan Pumice Mine and about $100 \mathrm{~km}$ southeast of Glass Mountain. The composite section is more than $800 \mathrm{~m}$ thick and consists of six linked, measured sections in fluvial, debrisflow, and lacustrine deposits (Reheis and others, 1991; Reheis, 1992)(figs. 1, 14, 15). The area has been mapped in detail because of its stratigraphic and tectonic setting adjacent to the northern Furnace Creek Fault Zone, and the sections have been intensively studied because of the presence of numerous air-fall and reworked tephra layers - more than 55 layers have been sampled and analyzed. The three measured sections in the upper $500 \mathrm{~m}$ of the Willow Wash section are late Pliocene in age; from bottom to top, they are called the Playa, Rimrock, and Badlands sections (fig. 15). At the base of the lacustrine deposits of the Playa section are two tephra layers (FLV-96- and -97-WW) identified as the 3.4-Ma Putah and 3.3 Ma Nomlaki Tuff Members of the Tehama Formation (Reheis and others, 1991; fig. 15).

About $175 \mathrm{~m}$ above the Putah and Nomlaki Tuff layers, at the top of the Playa section and near the base of the Rimrock section, are two closely spaced tephra layers (FLV-22- and -23-WW) that correlate chemically with the tuff of Benton Hot Springs, the basal tephra layers at the Cowan Pumice Mine (TTC-26A, B, $2.81 \mathrm{Ma}$; tables 1 and 4; fig. 7, 14, 15). We have obtained a direct ${ }^{40} \mathrm{Ar}{ }^{\beta 9} \mathrm{Ar}$ laser-fusion age of $2.89 \pm 0.03 \mathrm{Ma}$ on sample FLV-23-WW within the Rimrock section. This age is very similar, within the range of analytical errors, to that obtained on the tuff of Benton Hot Springs, $2.81 \pm 0.02 \mathrm{Ma}$, at the Cowan Pumice Mine (appendix 1).

We have attempted to obtain direct ${ }^{40} \mathrm{Ar} /{ }^{\beta 9} \mathrm{Ar}$ laser-fusion ages on feldspars contained in several tephra layers within the Willow Wash section. Most of these layers contained very small feldspar crystals that were too small to date successfully by this method. Attempts were made to pick out the coarsest feldspar crystals present in these layers, regardless of whether they had glass coatings or not, but most of these grains turned out to be detrital contaminants from older units (appendix 3 ).

Seven more tephra layers are present within an interval $140 \mathrm{~m}$ thick above the tuff of Blind Spring Valley in the Rimrock section. Six tuff layers of this set (FLV-24-through -29WW) correlate chemically with nine tephra layers (FLV-32through -34-, -121-, -35- through -37-, -138-, and -38-WW) in the nearby Badlands section (table 4 fig. 15). Because of the chemical similarity of their glass shards, it is not possible to correlate individual tephra layers between these two sections on the basis of EMA alone, but the tuffs can be correlated as a chemically relatively homogenous group between the two sections. We refer to this set of tephra layers as the (informal) tuffs of the Badlands. This set of tephra layers, like the tuff(s)

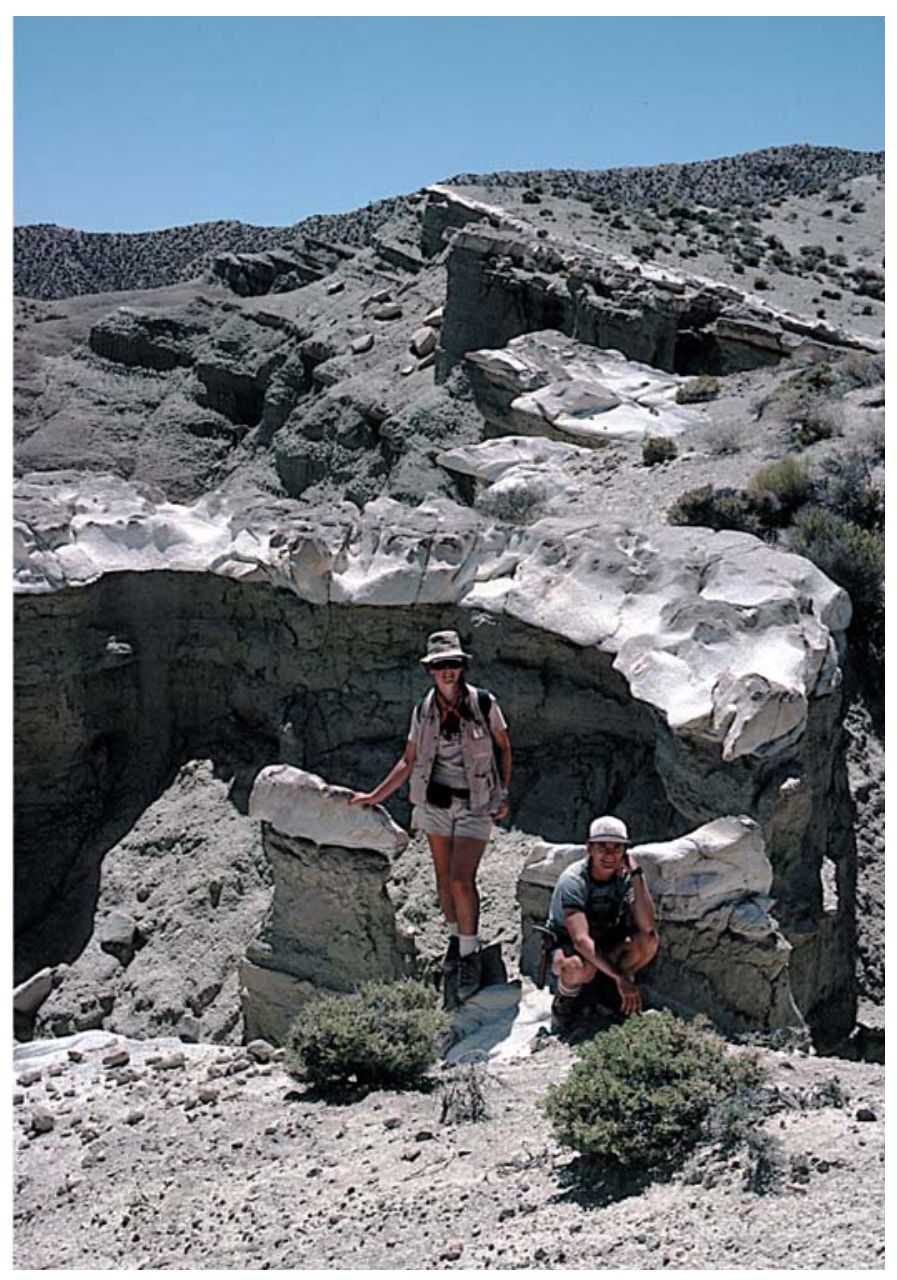

Figure 14. Tuff of Benton Hot Springs, near base of Rimrock section at Willow Wash, California-Nevada. This tuff is referred to informally as the "Rimrock ash bed" in this area (Reheis and others, 1991). The tuff is dated here as $2.87 \pm 0.03 \mathrm{Ma}$ by ${ }^{40} \mathrm{Ar} /{ }^{39} \mathrm{Ar}$ laser-fusion method. At the Cowan Pumice Mine in Blind Spring Valley, the same tuff, as determined by chemical correlation, is dated as $2.81 \pm 0.02 \mathrm{Ma}$ by the same method. View to west. See also figure 15, showing the stratigraphy at this locality, and figure 19 , showing correlation of the Willow Wash section with other localities in the region. 


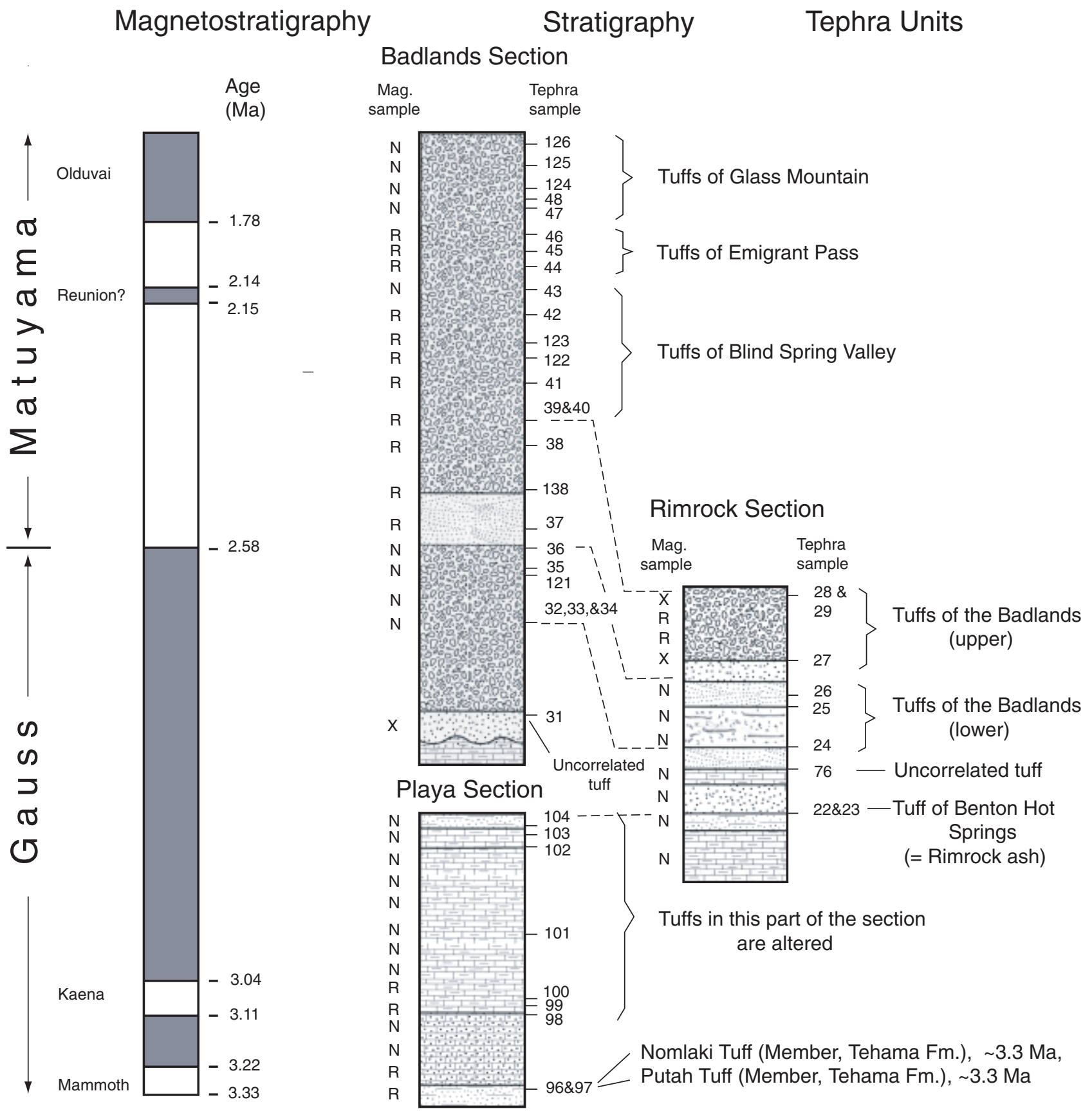

\begin{tabular}{|c|c|c|c|c|}
\hline & Magnetostratigraphy & \multicolumn{2}{|l|}{ Explanation } & Lithology \\
\hline & Normal magnetic polarity & & \% & Coarse, sandy conglomerate \\
\hline & Reversed magnetic polarity & $\begin{array}{l}\text { Meters } \\
\ulcorner 0\end{array}$ & & Pebbly, crossbedded sandstone \\
\hline & $\begin{array}{l}\text { Position of sample in section; magnetic } \\
\text { orientation normal }\end{array}$ & & & Sandstone \\
\hline $\mathrm{R}-$ & $\begin{array}{l}\text { Position of sample in section; magnetic } \\
\text { orientation reversed }\end{array}$ & -50 & - & Silty sandstone \\
\hline & Tephrostratigraphy & & & Gypsiferous mudstone or claystone \\
\hline $\begin{array}{r}29- \\
----\end{array}$ & $\begin{array}{l}\text { Tephra sample } \\
\text { Tephra layers correlated between sectior }\end{array}$ & $L_{100}$ & & Mudstone with interbedded sandstone \\
\hline
\end{tabular}

Figure 15. Stratigraphy of sections at Willow Wash, south of Fish Lake Valley, California-Nevada. 
of Benton Hot Springs, bears a family resemblance to the tuffs of Blind Spring Valley at the Cowan Pumice Mine.

A magnetic polarity transition, from normal below to reversed above, is present within the stratigraphic interval containing the tuffs of the Badlands, in both the Badlands and Rimrock sections, and was identified as the Gauss Normal Polarity Chron-Matuyama Reversed Polarity Chron boundary, on the basis of the correlated ages of the tephra layers in these sections (Reheis and others, 1991). This additional datum allows us to divide the tuffs of the Badlands into lower and upper sets. The lower set in the Badlands section (FLV-24-, -25-) and in the Rimrock section (FLV-32- through -34-, -121-, and $-35-\mathrm{WW}$ ) is bracketed in age between $\sim 2.89 \mathrm{Ma}$, below, and the Matuyama-Gauss polarity chron boundary, $2.57 \mathrm{Ma}$ (McDougall and others, 1992), above. The upper set in the Badlands section (FLV-26- through -29-WW) and in the Rimrock section (FLV-37-, -138-, and -38-WW) is bracketed between 2.57 Ma, below, and the correlated age of the tuffs of Blind Spring Valley, $\sim 2.22 \mathrm{Ma}$, present higher in the section (fig. 15; table 4)

Many tephra layers are present within alluvial fan gravels above the tuffs of the Badlands. FLV-39- through -43-WW and FLV-122- and -123-WW correlate with the tuffs of Blind Spring Valley at the Cowan Pumice Mine and are thus $~ 2.22$ to $2.14 \mathrm{Ma}$. FLV-43-WW is a single, normally magnetized unit within reversely magnetized sediments of the Matuyama Reversed Chron, and thus it was probably deposited during one of the Reunion Normal magnetostratigraphic events. The Huckleberry Ridge ash bed has not been found in this section, but from our tephra correlations, we would have expected it to be situated above FLV-43-WW; the next higher layers, FLV-44- and -45-WW, correlate with the tuffs of Emigrant Pass, which closely overlie the Huckleberry Ridge ash bed in northeast Fish Lake Valley (figs. 13, 15; summary correlations shown in figs. 19, 21; table 4). Highest in the Badlands section is a set of six tephra layers that correlate well on the basis of their glass chemistry with the lower tuffs of Glass Mountain (FLV-46- through -48-WW, and FLV-124- through -126-WW). For example, FLV-47- and -48-WW match well with TTC-23 and -24, the lower tuffs of Glass Mountain at the Cowan Pumice Mine (tables 1 and 4; figs. 7, 8, 15).

A reversed-to-normal paleomagnetic transition is present between tephra layers FLV-46-WW and FLV-47-WW and is identified as the basal boundary of the Olduvai Normal Subchron. The age of this subchron was recently estimated as between 1.98 and $1.96 \mathrm{Ma}$ for the lower boundary and 1.79 to 1.77 Ma for the upper (McDougall and others, 1992; Obradovich and Izett, 1992). Thus, FLV-46-WW must be younger than $\sim 2.06 \mathrm{Ma}$, the age of the Huckleberry Ridge ash bed, but older than $1.97 \mathrm{Ma}$, the age of the base of the Olduvai Normal Subchron. The five highest tephra layers in the Badlands section, all normally magnetized, must then be bounded in age by the Olduvai Normal Subchron $(\sim 1.97$ to $\sim 1.78 \mathrm{Ma})$.

\section{Yellowjacket Canyon, Chalfant Valley, East-central California}

The tuffs of the Badlands section at Willow Wash are correlated to Yellowjacket Canyon, several kilometers southeast of the Cowan Pumice Mine. At Yellowjacket Canyon, three tephra layers are present in a stratigraphic section of fine-grained alluvium about $175 \mathrm{~m}$ thick (YJC-2, -3, and -4). On the basis of their stratigraphic position and electron-microprobe analysis of the glass, the lower two layers correlate with the older set mentioned above ( 2.84 to $\sim 2.57 \mathrm{Ma}$ ), while the uppermost third layer correlates with the younger set $(\sim 2.57$ to $\sim 2.22 \mathrm{Ma})$ and not with the "Tuff of Taylor Canyon" of Izett and others (1988; our tuffs of Blind Spring Valley). Near the head of Yellowjacket Canyon, the sequence is unconformably overlain by the Bishop Tuff (YJC-1; fig. 16, and summary correlations in figs. 19 and 21).

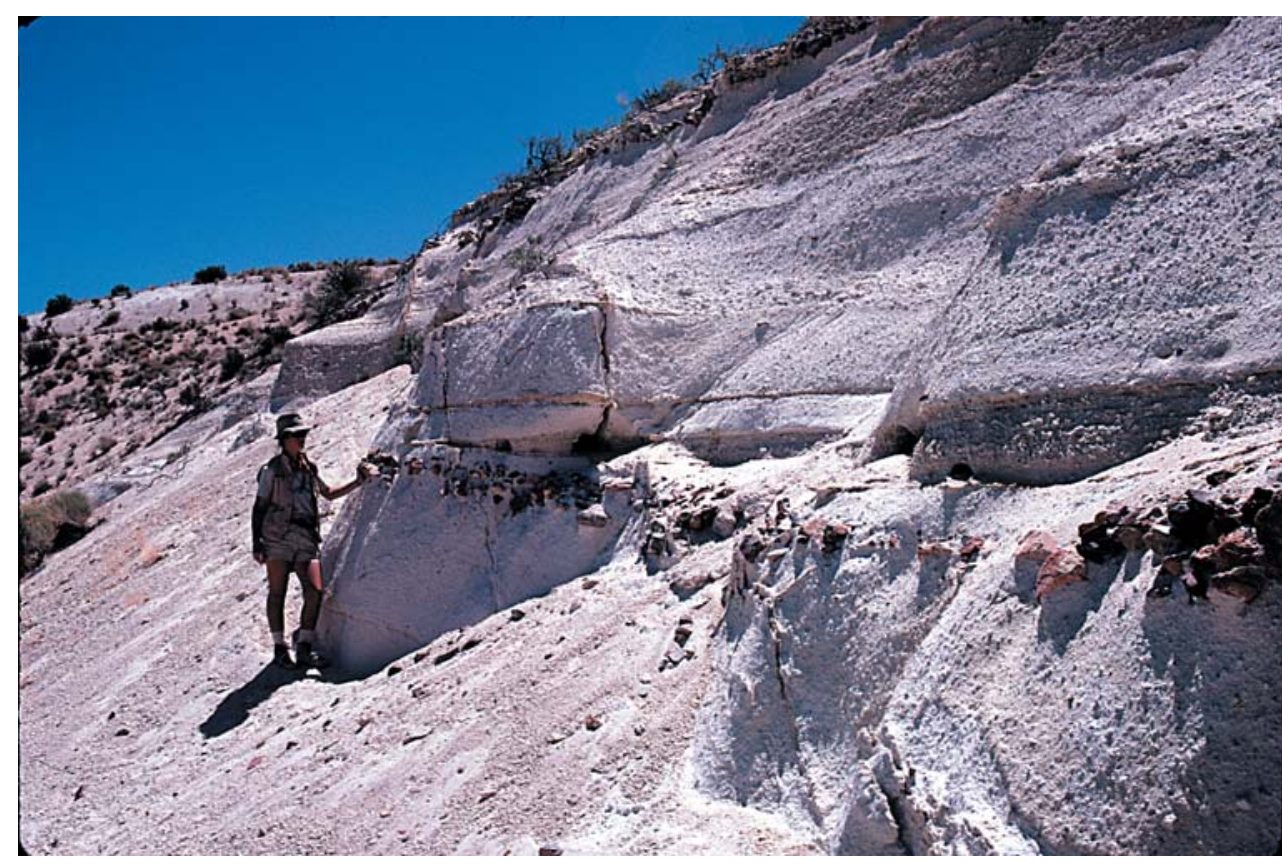

Figure 16. Bishop Tuff (ash-fall and ash-flow deposits) near head of Yellowjacket Canyon, east-Central California (see fig. 2), where sample YJC-1 was obtained. Angular clasts of local bedrock are entrained in the ash flow at the level of the geologist's left hand and also higher in the unit, near top. 


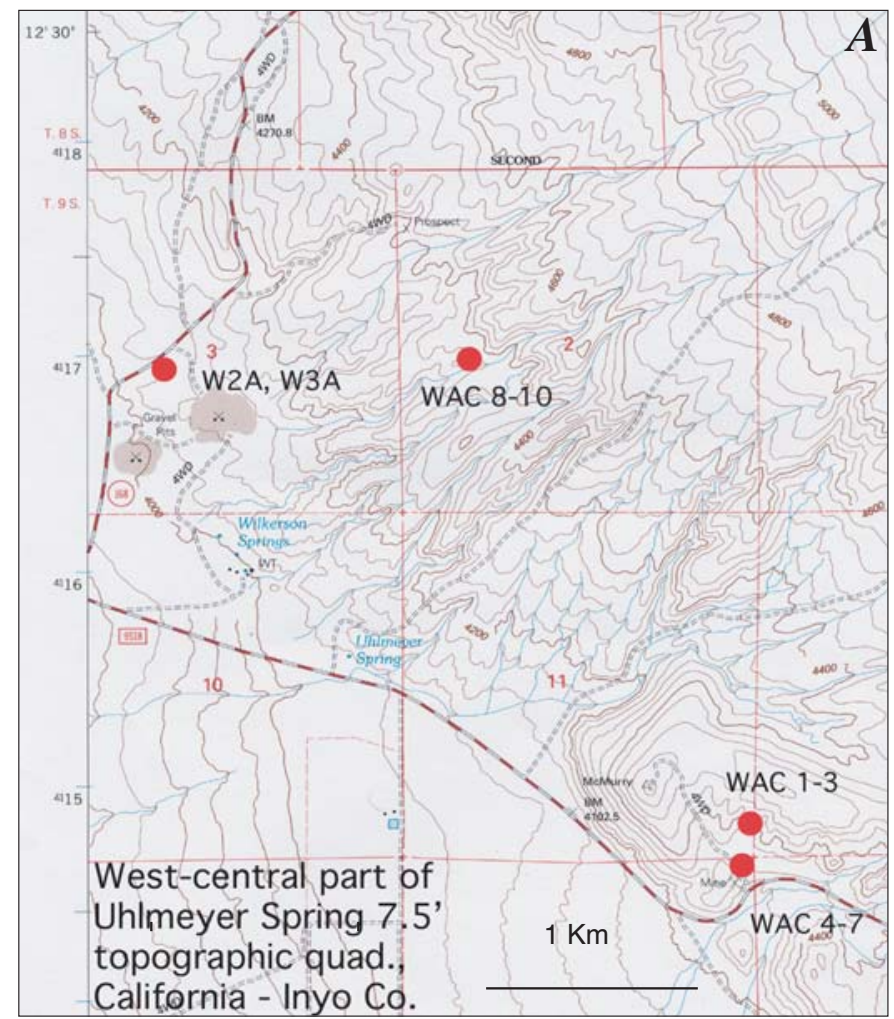

\section{Waucoba Lake Beds, Near Big Pine, Owens Valley, California}

Tephra layers correlative with the tuffs of Blind Spring Valley and Glass Mountain are present in ancient lake beds and overlying gravel exposed on the eastern side of Owens Valley, about $6 \mathrm{~km}$ northeast of the town of Big Pine, about $70 \mathrm{~km}$ south of the Cowan Pumice Mine (figs. 1, 17; table 6). The layers are known from three localities in a triangular area, separated from each other by about $3 \mathrm{~km}$, in the Waucoba Beds of Hopper (1947). A few of the layers appear to be clean, pure vitric ash beds, either direct airfall or water lain, but most beds are impure and probably reworked.

At one locality, near Westgard Road, two tephra layers were sampled from a sequence of lacustrine silts containing some sandy and pebbly beds (R.L. Hay, written commun., 1980). On the basis of electron-microprobe data, the lower of the two (W2A) matches well with the tuffs of Blind Spring Valley at the Cowan Pumice Mine (TTC-21) and with tuffs of Blind Spring Valley in the Emigrant Pass section of Fish Lake Valley, beneath the Huckleberry Ridge ash bed. Comparing EMA data, the upper of the two (W3A) matches equally well with tuffs just below the Huckleberry Ridge ash bed (tuffs of Blind Spring Valley) and with tuffs just above it (tuffs of Emi-
Meters

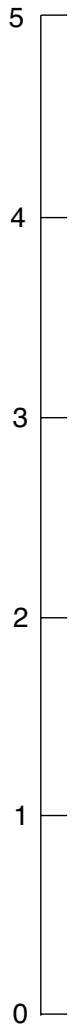

WAC-7<smiles>[Te]C#[Te]</smiles>

$-6 A-$

WAC- 6

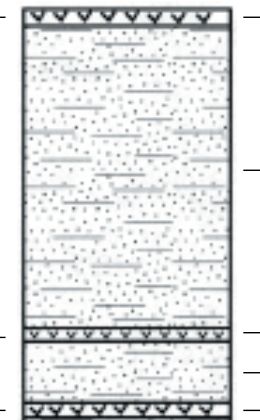

-

- Well-bedded lacustrine silts

Very fine, well-bedded, uniform laminae of tuff and silty tuff with partings of silt. Upper half is transitional into lacustrine silts; sharp basal contact

- Well bedded, lacustrine silt, mostly non-volcanic

WAC-4

Massive, silt-sized tephra layer; sharp upper and basal contacts

Well-bedded lacustrine silts, mostly non-volcanic

WAC-5

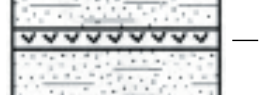

Fine pumice lapilli to $3 \mathrm{~mm}$ at base, overlain by fine tephra layer interbedded with fine pumice lapilli tephra, gradational upward into lacustrine silt; sharp basal contact.

Well-bedded lacustrine silt, mostly non volcanic

Fine, massive pumice lapilli tuff, lapilli 2-3 mm longest axis, at base; overlain by coarse pumicelapilli tuff, $13 \mathrm{~cm}$ thick, with lapilli to $1.3 \mathrm{~cm} \mathrm{I.a.,}$ and intebeds of fine tephra and tuffaceous or silty tephra, $0.6-1.3 \mathrm{~cm}$ thick. Gradational upward; sharp basal contact.

Figure 17. Locality map $(A)$ and stratigraphic section $(B)$ showing positions of tephra layers and samples in the Waucoba Lake Beds, north of Big Pine, Owens Valley, Calif. 
Table 6. Results of electron-microprobe analysis of glass from tephra layers in exposures of the Waucoba lake beds, east side of Owens Valley, $\sim 6 \mathrm{~km}$ east of Big Pine, Calif. [Samples of tephra layers are arranged according to stratigraphic position in each section, with youngest at top. Values given are weight-percent oxide, recalculated to 100 percent. Original oxide totals before recalculation are given to indicate approximate degree of hydration of volcanic glass. About 15 or more individual glass shards were analyzed for each sample. Electron-microprobe chemical analyses by C. E. Meyer.]

\begin{tabular}{|c|c|c|c|c|c|c|c|c|c|c|}
\hline Sample & $\mathrm{SiO}_{2}$ & $\mathrm{Al}_{2} \mathrm{O}_{3}$ & $\mathrm{Fe}_{2} \mathrm{O}_{3}$ & $\mathrm{MgO}$ & MnO & $\mathrm{CaO}$ & $\mathrm{TiO}_{2}$ & $\mathrm{Na}_{2} \mathrm{O}$ & $\mathrm{K}_{2} \mathrm{O}$ & Total \\
\hline \multicolumn{11}{|c|}{ Tuff of Emigrant Pass (W3A), and tuffs of Blind Spring Valley (?) (W2A) in lacustrine silts, locality 1, near Westgard Road } \\
\hline W3A & 77.5 & 12.4 & 0.65 & 0.03 & 0.09 & 0.32 & 0.05 & 3.61 & 5.35 & 93.2 \\
\hline W2A & 77.4 & 12.5 & 0.60 & 0.03 & 0.08 & 0.34 & 0.08 & 3.30 & 5.74 & 93.0 \\
\hline
\end{tabular}

Tuffs of Blind Spring Valley in lacustrine silts and sands (WAC-7, WAC-6), and uncorrelated tephra layers (WAC-5 and WAC-4),

\begin{tabular}{|c|c|c|c|c|c|c|c|c|c|c|}
\hline WAC-7 & 77.2 & 12.8 & 0.59 & 0.03 & 0.09 & 0.37 & 0.06 & 4.16 & 4.75 & 94.5 \\
\hline WAC-6 & 77.2 & 12.7 & 0.60 & 0.04 & 0.06 & 0.34 & 0.09 & 3.98 & 4.94 & 95.2 \\
\hline WAC-5 & 77.1 & 12.8 & 0.63 & 0.04 & 0.05 & 0.39 & 0.08 & 3.96 & 4.91 & 94.1 \\
\hline WAC-4 & 74.9 & 16.8 & 1.89 & 5.53 & 0.00 & 0.82 & 0.18 & 0.21 & 0.22 & 66.0 \\
\hline
\end{tabular}

Tuffs of Blind Spring Valley (DG-1, DG-3a?, DG-4), and uncorrelated tephra layer, possibly tuff of Emigrant Pass, (DG-2) in section transitional from lacustrine silts and sands (below) to alluvial fan gravels (above), locality 3, along Waucoba Road

\begin{tabular}{|c|c|c|c|c|c|c|c|c|c|c|}
\hline DG-1 & 76.9 & 13.0 & 0.53 & 0.03 & 0.10 & 0.34 & 0.06 & 4.27 & 4.87 & 94.6 \\
\hline DG-2 & 76.9 & 12.9 & 0.68 & 0.03 & 0.06 & 0.34 & 0.05 & 4.30 & 4.78 & 94.5 \\
\hline DG-3a & 76.9 & 12.9 & 0.63 & 0.02 & 0.09 & 0.31 & 0.05 & 4.45 & 4.63 & 94.3 \\
\hline DG-4 & 77.0 & 13.0 & 0.56 & 0.04 & 0.09 & 0.33 & 0.08 & 4.00 & 4.92 & 94.5 \\
\hline
\end{tabular}


grant Pass). Some variation in the alkalies and iron preclude a more definitive correlation on the basis of EMA analysis. Results of INAA analysis of glass of this tephra layer, however, correlate it with the upper of two tephra layers overlying the Huckleberry Ridge ash bed in the Manix basin of the Mojave Desert (see the summary correlation diagrams, figs. 19, 21) and thus favor correlation of W3A with the tuffs of Emigrant Pass or the lower tuffs of Glass Mountain, both sets of which overlie the Huckleberry Ridge ash bed in northern Fish Lake Valley.

At a second locality, along Waucoba Road, five tephra layers are exposed in lacustrine silt and sand beds within $\sim 5 \mathrm{~m}$ of section (fig. 17). The basal layer (WAC-4) is an altered pumice lapilli tuff, unusually enriched in magnesium and depleted in alkalies (table 6). This layer does not match with any other layer we have studied, most likely because of its advanced degree of alteration. It is overlain by another pumice lapill tuff (WAC-5) that is somewhat similar in overall composition to the Bishop ash bed, although it has considerably less iron. This tuff must be older that the Bishop ash bed, however, as is indicated by the correlation of other tephra layers in this section. Above this tuff (WAC-5) is a fine-grained vitric tuff (WAC-6) that matches best with the tuffs of Blind Spring Valley (TTC-20, TTC-22). A thin, impure tuff overlying WAC-6 was not analyzed. At the top of the section is a massive, silty, fine-grained vitric tuff (WAC7; fig. 17) that also matches well with the tuffs of Blind Spring Valley (TTC-4, -5, and others).

In a third area southeast of the second locality, four tephra layers are exposed along a 5-km length of Waucoba Road. These tephra layers are presumed to be in stratigraphic order in a gently westward-dipping section of fan gravel that ovelies the Waucoba lake beds, but the section is poorly exposed and it is possible that part of the section is repeated by unrecognized faults. The lowermost of the four tuffs (DG-4), at the top of the lacustrine section, is directly overlain by fan gravel. This tuff matches well with the tuffs of Blind Spring Valley at the Cowan Pumice Mine (TTC-6) and in northeastern Fish Lake Valley near Emigrant Pass (FLV-185-EP). The next tuff up in the section (DG-3a), within the overlying fanglomerate, also matches the tuffs of Blind Spring Valley (for example, TTC-6). The third tuff (DG-2) is chemically similar to some of the uppermost tuffs at Willow Wash, within the Badlands section, but there are no secure matches. The highest tuff in this section (DG-1) again matches very well with the tuffs of Blind Spring Valley (TTC-17, -9, -9A) and correlative units at Willow Wash (for example, FLV-40-WW; tables 4, 6; see the summary correlation diagrams, figs. 19, 21).

Most of the tuffs in the Waucoba beds appear to correlate best with the tephra layers of Blind Spring Valley, thus placing them within an age range of $\sim 2.22$ to $\sim 2.14 \mathrm{Ma}$, and possibly with the tuffs of Emigrant Pass, 2.05-2.00 Ma, but the correlation of the remainder is uncertain. New work indicates that the Waucoba Lake Beds are overlain by fan gravels containing the Bishop ash bed ( 0.76 Ma), and additional new work in the nearby Black Canyon indicates that a section very similar to that found at the Emigrant Pass section (see above) is present in that area (unpublished data, E. Kirby, A. SarnaWojcicki, M. Reheis, and D. Burbank, 2002).

According to Christopher Pluhar (University of California, Santa Cruz, written commun., 2004), all laustrine samples analyzed by him for paleomagnetic orientation from north of Waucoba Road in this region were reversed, and thus they must be older than $0.78 \mathrm{Ma}$, and also not of Olduvai age.

\section{Correlation of the Tuffs of Blind Spring Valley and Related Tephra Layers to Distal Sites in the Western United States}

Fine-grained tephra layers of the same chemical composition and age as the tuffs of Blind Spring Valley, and stratigraphically related tephra layers, are identified over a large area $\left(\sim 200,000 \mathrm{~km}^{2}\right.$; fig. 1) in the western United States. There are no other known volcanic source areas of both similar age and composition in western North America; thus these finegrained layers can be safely inferred to correlate with the tuffs of Blind Spring Valley and its stratigraphically related layers. Taken together, these layers provide unique and identifiable chronostratigraphic reference datum levels for late Pliocene time in the western conterminous United States.

\section{Confidence Hills, Death Valley, Southeastern California}

Deformed lake beds of silt, clay, mud, and sand intercalated with gravel, gypsiferous beds, and halite in the Confidence Hills of southern Death Valley, southeastern California (Troxel and Butler, 1986; Troxel and others, 1986; Pluhar and others, 1992; Beratran and Murray, 1992), contain multiple tephra layers that correlate with tephra layers in several other sections discussed above and below (figs. 1, 18; table 7).

Samples of the basal tephra layers in the Confidence Hills (CHA86BT-1; CH88004 and CH88006) correlate on the basis of glass composition and stratigraphic position with the tuffs of Blind Spring Valley at the Cowan Pumice Mine. Good matches are also obtained, of course, with our identified layers of the tuffs of Blind Spring Valley in the Willow Wash section south of Fish Lake Valley (FLV-39 through 43-WW and FLV122, 123-WW) (fig. 15; tables 4, 7), and elsewhere.

Above the basal tuffs at the Confidence Hills locality is the Huckleberry Ridge ash bed (CHA86 BT-2; CH88007; table 7). This ash bed (actually an indurated tuff at this locality) is used as the reference point for correlation of the measured sections of Troxel and others (1986) and B. W. Troxel (written commun, 1988) with that of Beratran and Murray (1992)(fig. 18). Note that the laser-fusion ${ }^{40} \mathrm{Ar} /{ }^{39} \mathrm{Ar}$ age we obtain for the Huckleberry Ridge ash bed is 2.056 $\pm 0.007 \mathrm{Ma}$, and Pluhar and other's (1992) age estimate of this tephra layer, based on their magnetostratig- 


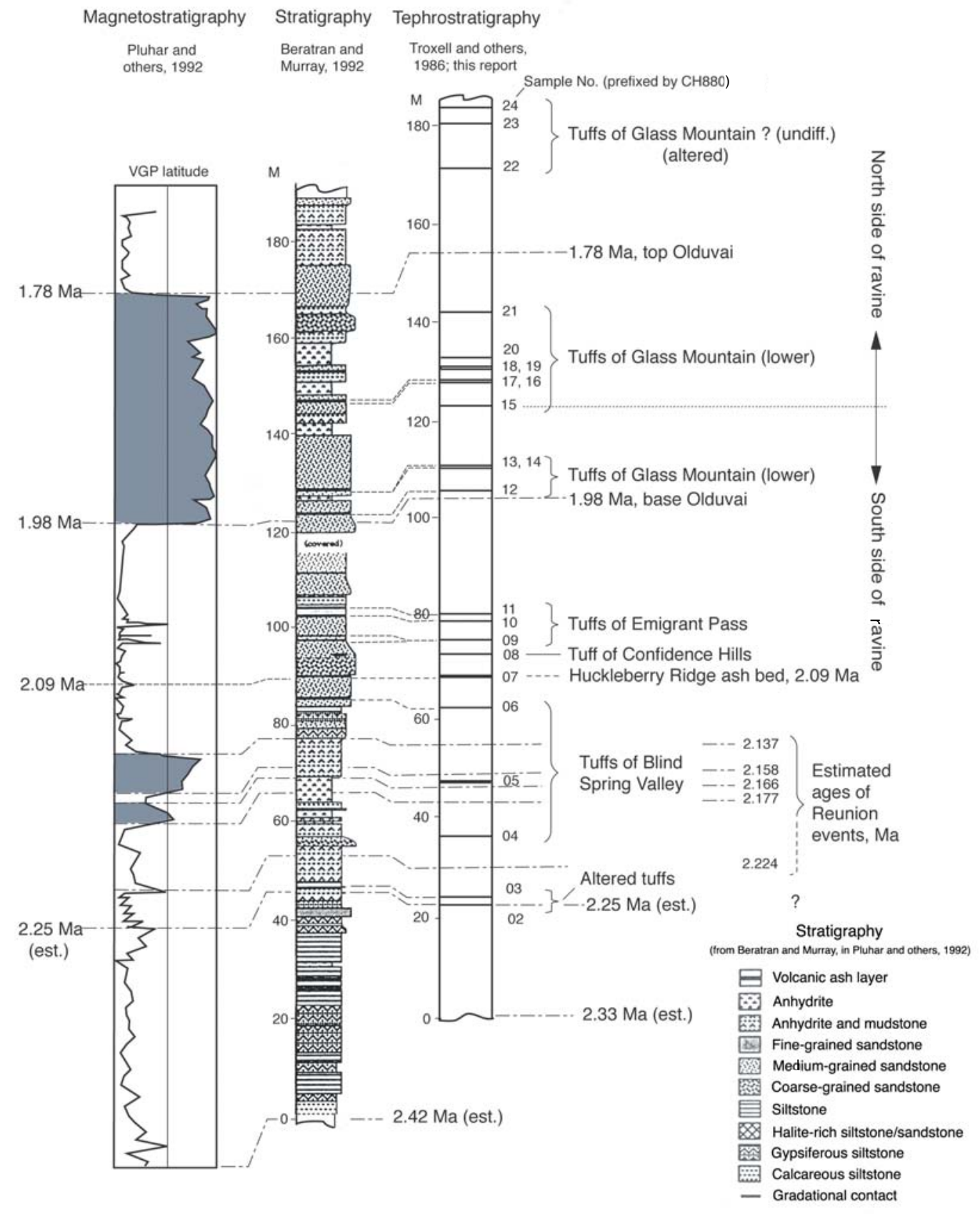

Figure 18. Magnetostratigraphy, stratigraphy, and tephrostratigraphy of a section exposed in the Confidence Hills, Death Valley National Park, California. Magnetostratigraphy determined by Pluhar and others (1992) in "Confusion Canyon" of Holt and Kirschvink (1995), and tephrostratigraphy of the same section, from Beratan and Murray (1992). The Huckleberry Ridge ash bed, sample 07, is common to both measured sections (Beratran and Murray, 1992; Troxell and others, 1986; this report) and is used as a reference for correlating the two sections and other tephra layers. Solid horizontal lines in tephrostratigraphy column are tephra layers. Dashed lines are time horizons connecting the same tephra layers or magnetostratigraphic boundaries. Sample numbers of tephra layers are prefixed by "CH880"; their analyses are given in table 7. Tuffs $02,03,05,15,22,23$, and 24 are altered and were not analyzed. Age control points used in interpolation of ages of undated horizons: top of the Olduvai Normal subchron-1.78 Ma; base of the Olduvai subchron-1.96 Ma; Huckleberry Ridge ash bed $-2.09 \mathrm{Ma}$ (our age of $2.057 \pm 0.008 \mathrm{Ma}$, multiplied by 1.0142 to convert to the more commonly used mineral standard MMhb-1 of 520.4 Ma given in Sampson and Alexander, 1987); altered tuff 02-2.25 (?) Ma (age is based on the assumption that tuffs 02,03 , and 05 correlate, like samples 04 and 06, with the tuffs of Blind Spring Valley; we use the age of the lowermost tephra layer of the tuffs of Blind Spring Valley, $2.219 \pm 0.006 \mathrm{Ma}$, multiplied by 1.0142, as above). 
Table 7. Glass chemical composition of tephra layers exposed in deformed alluvial and lacustrine sediments of the Confidence Hills, southern Death Valley, Calif. (Troxel and others, 1986; this report).

[Samples of tephra layers are arranged according to stratigraphic position in section (from uppermost to lowermost). Electron-microprobe chemical analyses by C. E. Meyer. Altered tephra samples (fig. 18) were not analyzed.]

\begin{tabular}{|c|c|c|c|c|c|c|c|c|c|c|c|}
\hline Sample & $\mathrm{SiO}_{2}$ & $\mathrm{Al}_{2} \mathrm{O}_{3}$ & $\mathrm{Fe}_{2} \mathrm{O}_{3}$ & MgO & MnO & $\mathrm{CaO}$ & $\mathrm{TiO}_{2}$ & $\mathrm{Na}_{2} \mathrm{O}$ & $\mathrm{K}_{2} \mathrm{O}$ & Total & Polarity \\
\hline \multicolumn{12}{|c|}{ Tuffs of Glass Mountain , undifferentiated (north side of gully) } \\
\hline CH88021 & 77.1 & 12.7 & 0.75 & 0.04 & 0.05 & 0.38 & 0.05 & 3.69 & 5.17 & 95.5 & Normal \\
\hline CH88020 & 77.1 & 12.7 & 0.77 & 0.03 & 0.03 & 0.41 & 0.07 & 3.69 & 5.25 & 94.7 & Normal \\
\hline CH88018A & 77.1 & 12.7 & 0.74 & 0.03 & 0.04 & 0.35 & 0.06 & 3.70 & 5.24 & 95.0 & Normal \\
\hline CH88017 & 77.1 & 12.8 & 0.75 & 0.03 & 0.04 & 0.36 & 0.05 & 3.82 & 5.05 & 95.7 & Normal \\
\hline CH88016 & 77.0 & 12.9 & 0.74 & 0.03 & 0.03 & 0.36 & 0.05 & 3.65 & 5.23 & 94.7 & Normal \\
\hline \multicolumn{12}{|c|}{ Tuffs of Glass Mountain , undifferentiated (south side of gully) } \\
\hline CH88014 & 76.8 & 12.9 & 0.76 & 0.02 & 0.07 & 0.32 & 0.06 & 3.71 & 5.32 & 94.3 & Normal \\
\hline CH88013 & 76.8 & 13.1 & 0.73 & 0.03 & 0.05 & 0.32 & 0.06 & 3.53 & 5.46 & 93.6 & Normal \\
\hline CH88012 & 76.8 & 13.1 & 0.71 & 0.02 & 0.07 & 0.30 & 0.05 & 3.68 & 5.25 & 93.6 & Normal \\
\hline \multicolumn{12}{|c|}{ Lower Tuffs of Glass Mountain (north side of gully) } \\
\hline CH86G9 & 79.0 & 11.7 & 0.72 & 0.05 & 0.03 & 0.44 & 0.06 & 3.26 & 4.88 & 93.5 & Reversed \\
\hline CH86G8 & 78.8 & 11.7 & 0.70 & 0.04 & 0.04 & 0.44 & 0.06 & 3.20 & 5.11 & 94.3 & Reversed \\
\hline CH86G6 & 78.7 & 11.9 & 0.70 & 0.03 & 0.04 & 0.38 & 0.05 & 3.21 & 4.98 & 94.7 & Reversed \\
\hline CH86W5 & 78.1 & 12.4 & 0.72 & 0.04 & 0.04 & 0.38 & 0.05 & 3.34 & 4.96 & 94.6 & Reversed \\
\hline \multicolumn{12}{|c|}{ Tuffs of Emigrant Pass (south side of gully) } \\
\hline CH88011 & 76.9 & 13.0 & 0.69 & 0.02 & 0.08 & 0.30 & 0.06 & 3.82 & 5.17 & 94.3 & Reversed \\
\hline CH88010 & 76.8 & 13.1 & 0.64 & 0.02 & 0.09 & 0.29 & 0.05 & 3.84 & 5.14 & 93.9 & Reversed \\
\hline CH88009 & 76.9 & 13.0 & 0.67 & 0.02 & 0.08 & 0.29 & 0.06 & 3.83 & 5.14 & 94.0 & Reversed \\
\hline CH86BT-3 & 77.8 & 12.4 & 0.64 & 0.02 & 0.09 & 0.29 & 0.06 & 3.53 & 5.23 & 94.1 & Reversed \\
\hline \multicolumn{12}{|c|}{ Tuff of Confidence Hills (south side of gully) } \\
\hline CH88008 & 70.9 & 15.6 & 2.71 & 0.28 & 0.09 & 0.96 & 0.29 & 5.06 & 4.06 & 91.8 & Reversed \\
\hline CH86GA4 & 72.4 & 14.9 & 2.57 & 0.24 & 0.08 & 1.02 & 0.30 & 4.71 & 3.86 & 92.7 & Reversed \\
\hline \multicolumn{12}{|c|}{ Huckleberry Ridge ash bed (south side of gully) } \\
\hline CH88007 & 75.9 & 12.8 & 1.79 & 0.02 & 0.03 & 0.59 & 0.12 & 3.61 & 5.09 & 92.4 & Reversed \\
\hline CH86BT2 & 77.1 & 12.0 & 1.71 & 0.01 & 0.05 & 0.59 & 0.11 & 3.33 & 5.17 & 92.9 & Reversed \\
\hline \multicolumn{12}{|c|}{ Tuffs of Blind Spring Valley (south side of gully; $\mathrm{CH} 88005$ is an altered tuff, and was not analyzed) } \\
\hline CH88006 & 76.7 & 13.1 & 0.62 & 0.03 & 0.07 & 0.36 & 0.07 & 3.77 & 5.28 & 93.9 & Reversed \\
\hline CH86BT1 & 77.8 & 12.4 & 0.58 & 0.02 & 0.09 & 0.33 & 0.06 & 3.55 & 5.17 & 94.7 & Reversed \\
\hline CH88004 & 76.7 & 13.2 & 0.64 & 0.05 & 0.09 & 0.34 & 0.08 & 3.80 & 5.13 & 93.0 & Reversed \\
\hline
\end{tabular}


raphy, is $2.09 \mathrm{Ma}$. The difference between their chronology and ours, about 34 k.y., may result from the different values used in the monitors for the age calibration of their magnetostratigraphic datum levels, and the ${ }^{40} \mathrm{Ar} /{ }^{39} \mathrm{Ar}$ ages we present here. If we multiply our age for the Huckleberry Ridge ash bed by 1.0143 , the correction factor between the two commonly used hornblende monitor values (Pringle and others, 1992; Renne and others, 1998; Sarna-Wojcicki and others, 2000), we obtain $2.086 \mathrm{Ma}$, very close to the 2.09-Ma interpolated age for the Huckleberry Ridge ash bed of Pluhar and others (1992).

Overlying the Huckleberry Ridge ash bed is a tuff (CH88008, CHA86-GA4) having a glass chemical composition that we have not seen before in association with the Huckleberry Ridge ash bed or the tuff of Taylor Canyon. We informally name this tephra layer the tuff of Confidence Hills. The age of this tuff is estmated to be $\sim 2.04 \pm 0.02 \mathrm{Ma}$, based on the age of the underlying Huckleberry Ridge ash bed, our isotopic chronology as correlated to the Confidence Hills, the overlying correlated tuffs of Emigrant Pass, and the corroborating magnetostratigraphy of Pluhar and others (1992). The tuff of Confidence Hills is derived from the Cascade Range volcanic province, as indicated by its chemical composition: high aluminum, iron, magnesium, calcium, and titanium concentrations, compared to tephra layers derived from the Glass Mountain and Yellowstone source areas.

Above the tuff of Confidence Hills are three tephra layers (CHA86 BT-3, which is the same layer as CH88009; CH88010 and CH88011) that match chemically with the tuffs of Emigrant Pass (FLV-189, 190-EP) near Emigrant Pass and at Willow Wash (FLV-44-, -45-, -46-WW) (figs. 13, 15, 18; tables $3,4,7)$. Because of their chemical similarity to the basal tephra layer in the sequence at the Confidence Hills, Troxel and others (1986) had previously speculated (after a suggestion by A.M. Sarna-Wojcicki) that these layers might represent a repetition of the basal layer (CHA86BT-1, CH8004) by isoclinal folding (the beds in the Confidence Hills are vertical). The new chemical correlations and associated chronology, however, when compared with the stratigraphic sequence, chemical compositions, and ages of tephra layers at other sites discussed here, provide a better match and more satisfactory explanation for the sequence of chemical types in the Confidence Hills and rule out the possibility of isoclinal folding. The above notwithstanding, the tuffs immediately above and below the Huckleberry Ridge ash bed in the Confidence Hills and Emigrant Pass sections are very similar in composition and hard to distinguish on the basis of EMA analysis alone. For example, compare CH88004, which underlies the Huckleberry Ridge ash bed, with CH88009, CH88010, and CHD88011, which overlie it (table 7). The only differences are in the concentrations of magnesium and calcium, and these are slight and not definitive within the error of EMA analysis. Follow-up analyses of these tuffs by a more precise technique for minor and trace elements, such as INAA or ICP-MS (inductively coupled plasma mass spectroscopy), are desirable, to test for possible significant differences in other trace and minor elements in order to distinguish these layers with confidence.
Above the tuffs of Emigrant Pass at the Confidence Hills are several younger tephra layers. One set of samples from these was collected in 1986 (CH86-WA5, CH86-GA6, CHA86-GWA7, CH86-GWA8, CHA86-GA9), another in 1988 (CH88012 through CH88014; CH88016 through CH88018-A; and CH88020 and CH99021). These tephra layers appear to grade, in terms of the chemical composition of their volcanic glasses, from tuffs that resemble the tuffs of Emigrant Pass, to tuffs that match in composition with the uppermost tephra layers in the Badlands section at Willow Wash, near Fish Lake Valley-that is, with the lower tuffs of Glass Mountain. For example, tephra layers CH88012 through CH88014 match well with tephra layers FLV-47-WW, -48-WW, and -125-WW at Willow Wash. These tephra layers undoubtedly all correlate with the tuffs of Glass Mountain. The lower of these tuffs at Confidence Hills are most similar to the lower tuffs of Glass Mountain at the Cowan Pumice Mine and to similar layers that are found above the tuffs of Emigrant Pass, in gravels that overlie the playa section containing the Huckleberry Ridge ash bed, in northeast Fish Lake Valley (figs. 8, 13). Combining the data from Troxel and others (1986), Pluhar and others (1992), and new analyses of the upper part of the Confidence Hills section presented here, the base of the Olduvai Normal Subchron within the Confidence Hills section is located above CH88011, which is reversed, and below CH88012, which is normal. As mentioned above, within the Willow Wash section the base of the Olduvai Normal Subchron is situated above FLV-46-WW, which is reversed, and below FLV-47-WW, which is normal (Reheis and others, 1991; figs. 15, 18).

Although the uppermost tephra layers in the Confidence Hills section (CH88012 through CH88021) and in the Willow Wash section (FLV-47-WW through FLV-126-WW) resemble the middle and upper tephra layers of Glass Mountain at Chalk Cliffs (BT-14, BT-15, and BT-16, ranging in age from $\sim 1.2$ to $0.8 \mathrm{Ma}$; table 2, figs. $12,15,18$ ), as well as the Bishop ash bed (TTC-7, $\sim 0.76 \mathrm{Ma}$; table 1 ), they cannot be younger than about $\sim 1.78 \mathrm{Ma}$, because they lie entirely within the Olduvai Normal Chron. Samples of nine additional tephra layers were collected throughout the Confidence Hills section in 1988 (CH88001 through CH88003; CH88005; CH88015; CH88019; and CH88022 through CH88025; fig. 18), but the volcanic glasses of these turned out to be altered and were not analyzed.

\section{Lake Tecopa, Southeastern California}

The Huckleberry Ridge ash bed is present in beds of ancient Lake Tecopa, east of Death Valley, in southeastern California (Sarna-Wojcicki and others, 1980, 1984; Izett, 1981). At most localities in Lake Tecopa, this tephra layer (Ash C of Sheppard and Gude, 1968) is altered to zeolites or authigenic potassium feldspar and cannot be identified by the methods used in this report. Only at one site, where this tephra layer has been uplifted within a small horst above correlative beds, has the unaltered Huckleberry Ridge tephra 
layer been identified (Sarna-Wojcicki and others, 1980, 1984, 1987). Thin, white, altered tephra layers stratigraphically close below the Huckleberry Ridge ash bed are likely to be the tuff of Blind Spring Valley, but unaltered exposures of these layers have not been found in this area. Stratigraphically higher above the Huckleberry Ridge ash bed in the Lake Tecopa section, both below and above structureless mud beds that we interpret to be playa deposits, are thin tephra layers that are chemically similar to the lower and upper tephra layers of Glass Mountain, and these are overlain in turn by the Bishop ash bed (Sarna-Wojcicki and others, 1980, 1984). This sequence is very similar and in large part coeval with the upper part of the sequence of tephra layers near Emigrant Pass in northeastern Fish Lake Valley, Nev., and in the upper part of the Confidence Hills in Death Valley (figs. 13, 18; also see summary correlation diagrams, figs. 19, 21). At Lake Tecopa, the entire sequence is overlain by the Lava Creek B ash bed, erupted from the area of Yellowstone in Wyoming. The age of the Lava Creek B ash bed has been most recently revised to $\sim 0.64 \mathrm{Ma}$ (Lanphere and others, 2002).

\section{Manix Basin, Central Mojave Desert, Southern California}

Three tephra layers are present in deformed lacustrine or playa deposits unconformably beneath late Pleistocene lake beds of the Manix basin, about $40 \mathrm{~km}$ east of Barstow, in the Mojave Desert of southeastern California (Sarna-Wojcicki and others, 1980, 1984; Izett, 1981; Izett and others, 1988; fig. 1). The basal ash bed (MANIX-6), about $3 \mathrm{~cm}$ thick, is the Huckleberry Ridge ash bed (Sarna-Wojcicki and others, 1984). A white ash bed (the middle white ash bed of Sarna-Wojcicki and others, 1984; MANIX-7 and -8) above the Huckleberry ridge ash bed was previously correlated with the uppermost tephra layer at the first of three localities in the Waucoba Road area mentioned above (W3A) on the basis of INAA analysis of the glass. This tephra layer also correlates well in terms of glass chemistry (EMA) and sequence with the tuffs of Emigrant Pass (for example, with FLV-189- and -190-EP; and with CHA86BT-3; figs. 13, 18; tables 3,8).

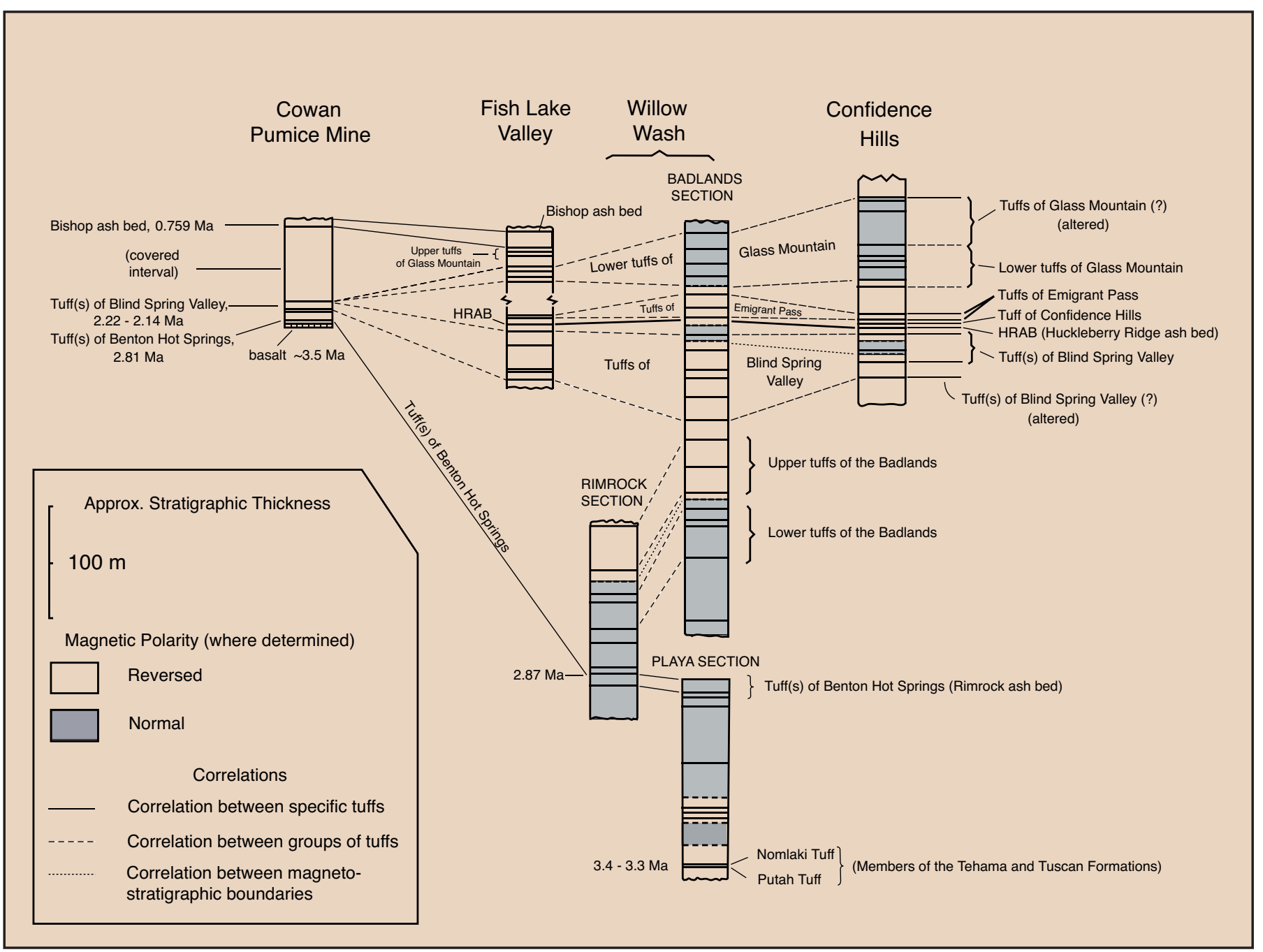

Figure 19. Correlation of the tuffs of Blind Spring Valley and other stratigraphically related units in the region of Glass Mountain and Long Valley, eastern California and western Nevada. See figures 1 and 2 for location of sections. 
Table 8. Glass chemical composition of tephra layers from several sites in southern and southwestern California and in Beaver Basin, Utah.

[Electron-microprobe chemical analyses by C. E. Meyer. See table 1 for additional comments.]

\begin{tabular}{|c|c|c|c|c|c|c|c|c|c|c|}
\hline Sample & $\mathrm{SiO}_{2}$ & $\mathrm{Al}_{2} \mathrm{O}_{3}$ & $\mathrm{Fe}_{2} \mathrm{O}_{3}$ & MgO & MnO & $\mathrm{CaO}$ & $\mathrm{TiO}_{2}$ & $\mathrm{Na}_{2} \mathrm{O}$ & $\mathrm{K}_{2} \mathrm{O}$ & Total \\
\hline \multicolumn{11}{|c|}{ Lake Tecopa, southeastern California. } \\
\hline \multicolumn{11}{|c|}{ Lower tuffs of Glass Mountain } \\
\hline TECO-23 & 76.8 & 13.0 & 0.77 & 0.03 & 0.04 & 0.37 & 0.07 & 3.42 & 5.52 & 93.5 \\
\hline TECO-31 & 76.7 & 13.1 & 0.73 & 0.02 & 0.05 & 0.39 & 0.06 & 3.43 & 5.54 & 94.1 \\
\hline TECO-24 & 76.6 & 13.1 & 0.76 & 0.03 & 0.03 & 0.44 & 0.07 & 3.65 & 5.37 & 93.6 \\
\hline \multicolumn{11}{|c|}{ Huckleberry Ridge ash bed } \\
\hline TECO-1 & 76.5 & 11.9 & 1.93 & 0.03 & 0.03 & 0.64 & 0.14 & 2.85 & 5.95 & 92.6 \\
\hline TECO-2 & 76.1 & 12.5 & 1.87 & 0.02 & 0.03 & 0.64 & 0.12 & 3.46 & 5.24 & 94.0 \\
\hline TECO-12B & 76.3 & 12.4 & 1.75 & 0.03 & 0.05 & 0.61 & 0.14 & 3.46 & 5.29 & 94.9 \\
\hline \multicolumn{11}{|c|}{ Manix Basin, Mojave Desert, Calif. } \\
\hline \multicolumn{11}{|c|}{ Tuffs of Emigrant Pass (?) } \\
\hline MANIX-7 & 77.9 & 12.6 & 0.66 & 0.03 & 0.06 & 0.30 & 0.05 & 4.77 & 3.60 & 94.5 \\
\hline MANIX-8 & 78.4 & 12.0 & 0.68 & 0.02 & 0.09 & 0.34 & 0.07 & 4.68 & 3.72 & 91.3 \\
\hline \multicolumn{11}{|c|}{ Huckleberry Ridge ash bed } \\
\hline MANIX- 6 & 76.2 & 13.0 & 1.63 & 0.03 & 0.03 & 0.61 & 0.13 & 4.07 & 4.37 & 94.8 \\
\hline \multicolumn{11}{|c|}{ Corona, Los Angeles Basin, Calif } \\
\hline \multicolumn{11}{|c|}{ Tuffs of Blind Spring Valley } \\
\hline $85-\mathrm{G}-54$ & 77.5 & 12.7 & 0.57 & 0.06 & 0.06 & 0.38 & 0.09 & 3.69 & 5.05 & 93.6 \\
\hline \multicolumn{11}{|c|}{ Ventura Basin, Calif. } \\
\hline \multicolumn{11}{|c|}{ Huckleberry Ridge ash bed } \\
\hline PICO-157(1) & 76.5 & 12.3 & 1.73 & 0.03 & 0.04 & 0.59 & 0.13 & 3.72 & 4.89 & 94.6 \\
\hline PICO-157(2) & 76.3 & 12.5 & 1.78 & 0.02 & 0.05 & 0.60 & 0.13 & 3.71 & 4.93 & 93.8 \\
\hline ASW-23-75-1 & 76.6 & 12.1 & 1.83 & 0.02 & 0.05 & 0.60 & 0.10 & 3.63 & 5.02 & 94.2 \\
\hline \multicolumn{11}{|c|}{ Tuffs of Blind Spring Valley } \\
\hline PICO-163Q & 76.9 & 13.5 & 0.60 & 0.04 & 0.10 & 0.32 & 0.07 & 3.86 & 4.56 & 93.6 \\
\hline PICO-169Q & 77.6 & 12.6 & 0.58 & 0.04 & 0.10 & 0.33 & 0.06 & 3.87 & 4.87 & 92.8 \\
\hline \multicolumn{11}{|c|}{ Beaver Basin, west-central Utah } \\
\hline \multicolumn{11}{|c|}{ Lower tuffs of Glass Mountain (Last Chance Bench ash bed, $10 \mathrm{~m}$ above Huckleberry Ridge ash bed) } \\
\hline LCB-1 & 77.4 & 12.6 & 0.74 & 0.04 & 0.04 & 0.43 & 0.06 & 4.04 & 4.65 & 92.5 \\
\hline \multicolumn{11}{|c|}{ Huckleberry Ridge ash bed } \\
\hline BEAVER-1 & 76.5 & 12.3 & 1.73 & 0.02 & 0.04 & 0.56 & 0.09 & 3.56 & 5.22 & 93.8 \\
\hline
\end{tabular}


Samples of the above two tephra layers were collected from localities on the north bank of the Mojave River. The tuff of Emigrant Pass (MANIX-7, 8) is also exposed on the south side of the Mojave River (MANIX 4). There, another tephra layer is present 12 to $15 \mathrm{~m}$ higher in the section (MANIX-2; the upper white ash bed of Sarna-Wojcicki and others, 1984). Neutron activation analysis indicates that the latter unit is broadly similar in glass chemistry to the tephra layers of Glass Mountain and the Bishop ash bed (table 8). We have no EMA analysis of this latter unit. Given its stratigraphic position, close above the tuffs of Emigrant Pass, it is most probably one of the tuffs of Glass Mountain.

According to Christopher Pluhar (University of California, Santa Cruz, written commun., 2003), the basal Huckleberry Ridge ash bed and the overlying middle white ash are reversely magnetized, while the upper white ash bed is normally magnetized. Thus, the middle white ash bed must be older than the base of the Olduval subchron, while the upper white ash bed is most likely of Olduvai subchron age.

\section{Peninsular Ranges, California}

Lenses of tephra are present in thin marine sediments that cover a weathered, eroded surface cut in granitic rocks in the northern part of the Peninsular Ranges of southern California, in the Rancho Sobrante e San Jacinto area, north of Corona (D. Morton, written commun., 1982; fig. 1, table 8; sample 85-G-54). The lenses of ash are preserved in what appear to be ancient tidal pools within a wave-cut marine platform. The sediments are overlain by a conglomerate. These tephra lenses match well with some tephra layers of the tuffs of Blind Spring Valley at the Cowan Pumice Mine (for example, with TTC-10), in the Willow Wash section (FLV-123-WW), and in the Waucoba lake beds (WAC-6)(tables 1, 4, and 5), and are here assigned to the tuffs of Blind Spring Valley.

\section{Ventura Basin, Southwestern Coastal California}

The Huckleberry Ridge ash bed has been identified in deformed and uplifted beds of the marine Pico Formation at South Mountain and Balcom Canyon, in the Ventura Basin (fig. 1; PICO-157, ASW-3-23-75-1; table 8; Sarna-Wojcicki and others, 1980, 1984, 1987), where the ash is situated stratigraphically far below a thin, white ash bed, estimated to be 1.5 Ma (Sarna-Wojcicki and others, 1984) and even farther below the Bailey ash bed (1.2 Ma, Izett and others, 1974; Sarna-Wojcicki and others, 1984). Both latter ash beds are correlated to the tuffs of Glass Mountain, and the Glass Mountain volcanic source area, on the basis of their glass chemical composition and age. The Huckleberry Ridge ash bed is fine-grained and only about 4 to $8 \mathrm{~cm}$ thick in this area. About $97 \mathrm{~m}$ stratigraphically below the Huckleberry Ridge ash bed is a 1-cm-thick ash bed (samples PICO-162Q and PICO-169Q) that correlates well on the basis of its glass chemical composition with tuffs of Blind Spring Valley (table 8). Although this ash bed is stratigraphically far below the Huckleberry Ridge ash bed, the sedimentation rates determined for this section based on the age and stratigraphic position of datum levels higher in the section, above the Huckleberry Ridge ash bed (Sarna-Wojcicki and others, 1987), are high, $\sim 0.72 \mathrm{~mm} / \mathrm{yr}$. An independent age estimate for this 1-cm-thick ash bed below the Huckleberry Ridge ash bed, based on the above sedimentation rate and the stratigraphic separation between the two units, is $2.19 \mathrm{Ma}$. This estimate is in good agreement with the isotopic age range of tuffs of Blind Spring Valley, supporting the identification of the PICO-162Q and -169Q as correlative with these tephra layers.

The range of chemical composition of the Huckleberry ridge ash bed as determined by EMA is given in table 9. Its age of $2.063 \pm 0.07 \mathrm{Ma}$, as determined in this study, is given in appendix 1 .

\section{Beaver Basin, West-central Utah}

According to Izett and others (1988), a tephra layer about $6 \mathrm{~cm}$ thick is present in Pliocene and Pleistocene sediments, about $30 \mathrm{~m}$ stratigraphically below the Huckleberry Ridge ash bed, in the Beaver Basin of west-central Utah (samples 78G174, 78G167, 79W98, and 79W99 of Izett and others, 1988; Machette and others, 1984; fig. 1), and this layer correlates well with their Taylor Canyon-C tephra layer at the Cowan Pumice Mine (samples 79G10 and 74W60; Izett and others, 1988; fig. 20). The INAA analysis of the samples from the Beaver Basin provides a convincing match with the tuff of Taylor Canyon of Izett and others (1988; our tuffs of Blind Spring Valley) at the Cowan Pumice Mine, and also with our INAA analyses of samples from the latter locality (TTC-5 and TTC-4, from pits 3 and 5, respectively; table 10). The INAA data, combined with our ${ }^{40} \mathrm{Ar} /{ }^{39} \mathrm{Ar}$ ages on sanidine from samples TTC-4 and TTC-5 (table 1), provide a correlated age of $\sim 2.14 \pm 0.01 \mathrm{Ma}$ for this tephra layer. Izett and others $(1982,1988)$ had previously obtained a slightly younger date of 2.10 \pm 0.02 Ma by conventional K-Ar on sanidine from their Taylor Canyon-C layer. The Beaver Basin is $\sim 540 \mathrm{~km}$ from the inferred source area of this tephra layer in eastern California; it is the farthest distal site of the tuffs of Blind Spring Valley (tuff of Taylor Canyon of Izett and others, 1988) found to date.

Our analysis of the Huckleberry Ridge ash bed from the Beaver Basin (BEAVER-1, table 9) corroborates those of Izett and others (1988). Our analysis of a thin, white tephra layer situated about $10 \mathrm{~m}$ stratigraphically above the Huckleberry Ridge ash bed in the Beaver Basin, the Last Chance Bench ash bed of Izett and others (1988), matches with the tuffs of Glass Mountain (sample LCB-1; tables 8, 9, 10).

\section{Discussion and Conclusions}

Tephra layers identified in this study on the basis of their glass chemical composition, combined with magnetostrati- 
Table 9. Glass chemical composition of the Huckleberry Ridge ash bed from sites in the western and central United States, as determined by electron-microprobe analyses.

[C. E. Meyer, analyst. See table 1 for additional explanation of analytical results.]

\begin{tabular}{|c|c|c|c|c|c|c|c|c|c|c|}
\hline Sample & $\mathrm{SiO}_{2}$ & $\mathrm{Al}_{2} \mathrm{O}_{3}$ & $\mathrm{Fe}_{2} \mathrm{O}_{3}$ & $\mathrm{MgO}$ & MnO & $\mathrm{CaO}$ & $\mathrm{TiO}_{2}$ & $\mathrm{Na}_{2} \mathrm{O}$ & $\mathrm{K}_{2} \mathrm{O}$ & Total \\
\hline \multicolumn{11}{|c|}{$\begin{array}{l}\text { Huckleberry Ridge ash bed, reference sample from alluvium, Borchers faunal locality, Meade County, Kan. (1-4) (Izett and Wilcox, 1982, analyzed in this study); in lake beds, near } \\
\text { Emigrant Pass in northern Fish Lake Valley, Nev. (5); in lake beds, Confidence Hills, Death Valley, Calif. (6, 7); in lake beds, Pleistocene Lake Tecopa, Calif. (8-10); in alluvium, Manix Basin } \\
\text { Mojave Desert, Calif. (11); in deep basinal marine sediments, Pico Fm., Ventura Basin, Calif. (12-14); and in lake beds, Beaver Basin, Utah (15). }\end{array}$} \\
\hline 1. 68W98(A) & 77.0 & 12.3 & 1.66 & 0.02 & 0.04 & 0.58 & 0.10 & 3.2 & 5.1 & ND \\
\hline 2. 68W98(B) & 76.7 & 12.5 & 1.69 & 0.02 & 0.03 & 0.58 & 0.10 & 3.3 & 5.1 & ND \\
\hline 3. 68W98(C) & 75.9 & 12.6 & 1.75 & 0.02 & 0.04 & 0.65 & 0.11 & 3.7 & 5.3 & 94.1 \\
\hline 4. $68 \mathrm{~W} 98(\mathrm{D})$ & 76.7 & 12.3 & 1.71 & 0.02 & 0.05 & 0.58 & 0.12 & 3.4 & 5.2 & 93.9 \\
\hline $\begin{array}{l}\text { 5. FLV-179- } \\
\text { EP7 }\end{array}$ & 76.6 & 12.1 & 1.72 & 0.01 & 0.04 & 0.59 & 0.11 & 2.8 & 6.0 & 93.1 \\
\hline 6. $\mathrm{CH} 88007$ & 75.9 & 12.8 & 1.79 & 0.02 & 0.03 & 0.59 & 0.12 & 3.6 & 5.1 & 92.4 \\
\hline 7. CH86BT2 & 77.1 & 12.0 & 1.71 & 0.01 & 0.05 & 0.59 & 0.11 & 3.3 & 5.2 & 92.9 \\
\hline 8. TECO-1 & 76.5 & 11.9 & 1.93 & 0.03 & 0.03 & 0.64 & 0.14 & 2.9 & 6.0 & 92.6 \\
\hline 9. TECO-2 & 76.1 & 12.5 & 1.87 & 0.02 & 0.03 & 0.64 & 0.12 & 3.5 & 5.2 & 94.0 \\
\hline $\begin{array}{l}\text { 10. TECO- } \\
12 \mathrm{~B}\end{array}$ & 76.3 & 12.4 & 1.75 & 0.03 & 0.05 & 0.61 & 0.14 & 3.5 & 5.3 & 94.9 \\
\hline $\begin{array}{l}\text { 11. MANIX- } \\
6\end{array}$ & 76.2 & 13.0 & 1.63 & 0.03 & 0.03 & 0.61 & 0.13 & 4.1 & 4.4 & 94.8 \\
\hline $\begin{array}{l}\text { 12. PICO- } \\
\text { 157(1) }\end{array}$ & 76.5 & 12.3 & 1.73 & 0.03 & 0.04 & 0.59 & 0.13 & 3.7 & 4.9 & 94.6 \\
\hline $\begin{array}{l}\text { 13. PICO- } \\
\text { 157(2) }\end{array}$ & 76.3 & 12.5 & 1.78 & 0.02 & 0.05 & 0.60 & 0.13 & 3.7 & 4.9 & 93.8 \\
\hline $\begin{array}{l}\text { 14. ASW-23- } \\
75-1\end{array}$ & 76.6 & 12.1 & 1.83 & 0.02 & 0.05 & 0.60 & 0.10 & 3.3 & 5.2 & 94.2 \\
\hline $\begin{array}{l}\text { 15. BEAVER- } \\
1\end{array}$ & 76.5 & 12.3 & 1.73 & 0.02 & 0.04 & 0.56 & 0.09 & 3.6 & 5.2 & 93.8 \\
\hline $\begin{array}{c}\text { Average, } \\
\text { x(15) }\end{array}$ & 76.5 & 12.4 & 1.75 & 0.02 & 0.04 & 0.60 & 0.12 & 3.4 & 5.2 & 93.8 \\
\hline $\pm 2 \sigma$ & 0.4 & 0.3 & 0.08 & 0.01 & 0.01 & 0.03 & 0.02 & 0.3 & 0.4 & 1.6 \\
\hline \multicolumn{11}{|c|}{ Huckleberry Ridge ash bed, average composition of 21 samples, from the western and central United States } \\
\hline $\begin{array}{l}\text { Average, } \\
\times(21)\end{array}$ & 76.4 & 12.4 & 1.74 & 0.02 & 0.04 & 0.59 & 0.12 & 3.6 & 5.1 & \\
\hline $\pm 2 \sigma$ & 0.6 & 0.4 & 0.10 & 0.02 & 0.02 & 0.04 & 0.04 & 0.5 & 0.6 & \\
\hline
\end{tabular}


Table 10. Instrumental neutron-activation analysis of selected samples of the tuff of Blind Spring Valley, from the Cowan Pumice Mine (TTC-), and correlative or chemically related tephra layers erupted from the Glass Mountain volcanic source area.

[Samples from the Waucoba lake beds of Hopper (1947) (WAC-;W2A, W3A), the Manix Basin (MANIX-), as well as the compositionally contrasting Huckleberry Ridge ash bed, erupted from the Yellowstone National Park area of Wyoming and Idaho, from several selected localities in the Western U.S. Values given are atomic weight in parts per million, except for iron, which is given in atomic weight percent. Analyses were done in the U.S. Geological Survey's Radiochemistry Laboratories at Denver (D): J. Budhan, R. Knight, and D. McKown, analysts; and Reston (R): P. Baedecker and J. Rowe, analysts; and at the University of California's Lawrence Berkeley Laboratory (L): F. Asaro, H. Bowman, and H. Michael, analysts. Numbers in parentheses after sample number are replicate analyses of the same sample.]

\begin{tabular}{|c|c|c|c|c|c|c|c|c|c|c|c|c|c|c|c|c|c|c|c|}
\hline Sample no. & $\mathrm{Sc}$ & $\mathrm{Mn}$ & $\mathrm{Fe}$ & $\mathrm{Rb}$ & Cs & $\mathrm{La}$ & $\mathrm{Ce}$ & $\mathrm{Nd}$ & $\mathrm{Sm}$ & $\mathrm{Eu}$ & $\mathrm{Tb}$ & Dy & $\mathrm{Yb}$ & $\mathrm{Lu}$ & $\mathrm{Hf}$ & $\mathrm{Ta}$ & Th & $\mathrm{U}$ & $\mathrm{Lab}$ \\
\hline \multicolumn{20}{|c|}{ Tuffs of Blind Spring Valley } \\
\hline TTC-5 & 3.03 & 639 & 0.40 & 251 & 7.8 & 18 & 44 & 19 & 4.4 & 0.06 & 0.71 & 4.8 & 3.1 & 0.43 & 4.3 & 3.2 & 22.3 & 9.7 & D \\
\hline TTC-4 & 3.14 & 638 & 0.41 & 259 & 7.9 & 18 & 46 & 19 & 4.5 & 0.07 & 0.72 & 5.0 & 3.2 & 0.40 & 4.5 & 3.4 & 22.7 & 10.1 & D \\
\hline TTC-6 & 3.36 & 694 & 0.40 & 281 & 9.0 & 17 & 48 & 22 & 4.8 & 0.06 & 0.82 & 5.6 & 3.5 & 0.48 & 4.6 & 3.6 & 24.2 & 11.2 & $\mathrm{D}$ \\
\hline \multicolumn{20}{|c|}{$\begin{array}{l}\text { Tephra Layers in the Waucoba lake Beds of Hopper (1947), Waucoba Road Locality, in stratigraphic order, with WAC-7 youngest } \\
\text { (WAC-6 correlates withTuffs of Blind Spring Valley, above) }\end{array}$} \\
\hline WAC-7 & 4.77 & 685 & 0.46 & 325 & 11.0 & 16 & 48 & 24 & 5.8 & 0.03 & 1.03 & 6.8 & 4.3 & 0.63 & 5.4 & 4.5 & 29.7 & 12.9 & D \\
\hline WAC-6 & 3.25 & 637 & 0.43 & 266 & 8.3 & 18 & 49 & 21 & 4.6 & 0.07 & 0.77 & 4.7 & 3.3 & 0.45 & 4.5 & 3.4 & 23.2 & 10.3 & D \\
\hline WAC-5 & 3.07 & 559 & 0.42 & 233 & 6.9 & 21 & 54 & 22 & 4.4 & 0.08 & 0.68 & 4.4 & 2.8 & 0.39 & 4.3 & 2.9 & 20.9 & 8.9 & $\mathrm{D}$ \\
\hline \multicolumn{20}{|c|}{$\begin{array}{l}\text { Tephra Layer in the Waucoba Lake Beds of Hopper (1947), east of Westgard Road Locality } \\
\text { (correlates with WAC-6, above, and withTuffs of Blind Spring Valley, above) }\end{array}$} \\
\hline WAC-10 & 3.24 & 599 & 0.42 & 267 & 8.4 & 19 & 49 & 21 & 4.6 & 0.07 & 0.77 & 5.0 & 3.2 & 0.46 & 4.6 & 3.4 & 23.5 & 10.6 & $\mathrm{D}$ \\
\hline \multicolumn{20}{|c|}{$\begin{array}{l}\text { Tephra Layers in the Waucoba Lake Beds of Hopper (1947), Westgard Road Locality, in stratigraphic order with W3A youngest } \\
\text { (W2A correlates with WAC-6, WAC-10, and with theTuffs of Blind Spring Valley) }\end{array}$} \\
\hline W3A(1) & 4.66 & 701 & 0.46 & 323 & 10.7 & 16 & 45 & 24 & 6.0 & 0.06 & 1.06 & 6.9 & 4.4 & 0.58 & 5.5 & 4.6 & 30.5 & 13.2 & $\mathrm{~L}$ \\
\hline W3A(2) & 4.62 & 676 & 0.45 & 320 & 10.5 & 15 & 48 & 24 & 5.7 & 0.02 & 1.00 & 6.5 & 4.1 & 0.58 & 5.3 & 4.4 & 29.2 & 12.9 & D \\
\hline W2A & 3.31 & 702 & 0.40 & 285 & 9.5 & 17 & 48 & 21 & 4.8 & 0.07 & 0.83 & 5.2 & 3.4 & 0.48 & 4.6 & 3.7 & 25.2 & 11.5 & $\mathrm{D}$ \\
\hline \multicolumn{20}{|c|}{$\begin{array}{l}\text { Tephra Layer in Alluvium of the Manix Basin, Mojave Desert: the Middle White Ash of Sarna-Wojcicki and others (1984) } \\
\text { (correlates with WAC-7, and is also very similar to W3A) }\end{array}$} \\
\hline MANIX-2 & 4.95 & 696 & 0.44 & 315 & 10.8 & 17 & 52 & 21 & 6.4 & $<0.01$ & 1.00 & 6.7 & 4.5 & 0.64 & 5.9 & 4.7 & 30.2 & 13.8 & $\mathrm{~L}$ \\
\hline MANIX-4 & 4.89 & 688 & 0.45 & 317 & 10.3 & 17 & 51 & 25 & 6.3 & $<0.01$ & 1.08 & 7.0 & 4.3 & 0.56 & 5.7 & 4.6 & 29.5 & 13.5 & $\mathrm{~L}$ \\
\hline MANIX-7 (1) & 5.00 & 705 & 0.48 & 326 & 11.2 & 18 & 54 & 26 & 6.1 & 0.02 & 1.07 & 6.7 & 4.4 & 0.63 & 5.6 & 4.6 & 29.3 & 13.3 & $\mathrm{D}$ \\
\hline MANIX-7 (2) & 4.86 & 698 & 0.46 & 327 & 11.1 & 18 & 52 & 27 & 6.3 & 0.02 & 1.04 & 7.1 & 4.5 & 0.60 & 5.8 & 4.7 & 29.7 & 13.5 & $\mathrm{~L}$ \\
\hline MANIX-8 & 4.92 & 701 & 0.45 & 321 & 10.6 & 17 & 52 & 27 & 6.4 & 0.03 & 1.04 & 7.2 & 4.4 & 0.58 & 5.9 & 4.7 & 29.7 & 13.4 & $\mathrm{~L}$ \\
\hline
\end{tabular}

The Huckleberry Ridge Ash Bed in the Manix Basin (MANIX-), Lake Tecopa (Teco-), Ventura Basin (ASW32375), and Humboldt Basin (Falor-2), California, and in the Sappa Formation, Meade County,

\begin{tabular}{|c|c|c|c|c|c|c|c|c|c|c|c|c|c|c|c|c|c|c|c|}
\hline \multicolumn{20}{|c|}{ Kansas (b8vv98) } \\
\hline MANIX-6(1) & 1.77 & 287 & 1.21 & 201 & 3.7 & 92 & 181 & 73 & 13.8 & 0.69 & 2.20 & 13.9 & 7.9 & 1.08 & 9.5 & 3.5 & 29.9 & 6.2 & $\mathrm{~L}$ \\
\hline MANIX-6(2) & 1.75 & 298 & 1.19 & 212 & 3.8 & 92 & 179 & 73 & 13.6 & 0.71 & 2.20 & 14.1 & 8.0 & 1.03 & 9.3 & 3.6 & 30.2 & 6.1 & $\mathrm{D}$ \\
\hline Тесо-1 & 1.75 & 305 & 1.25 & 189 & 2.8 & 102 & 189 & 78 & 14.3 & 0.81 & 2.00 & 13.4 & 7.1 & 1.00 & 9.0 & 3.0 & 27.8 & 5.6 & $\mathrm{~L}$ \\
\hline Тесо-2 & 1.80 & 310 & 1.28 & 192 & 3.2 & 102 & 201 & 80 & 14.3 & 0.89 & 2.00 & 13.6 & 7.6 & 1.05 & 9.6 & 3.3 & 28.1 & 5.6 & $\mathrm{~L}$ \\
\hline Teco-12 & 1.70 & 306 & 1.20 & 197 & 3.1 & 96 & 179 & 66 & 13.3 & 0.78 & 2.10 & 13.6 & 7.3 & 0.97 & 8.8 & 3.3 & 28.7 & 6.4 & $\mathrm{D}$ \\
\hline ASW32375(1) & 1.74 & 301 & 1.24 & 196 & 3.0 & 104 & 203 & 80 & 14.5 & 0.82 & 2.00 & 13.9 & 7.6 & 1.03 & 9.4 & 3.3 & 28.6 & 5.7 & $\mathrm{~L}$ \\
\hline ASW32375(2) & 1.80 & 308 & 1.24 & 204 & 3.3 & 104 & 201 & 81 & 14.7 & 0.85 & 2.10 & 13.7 & 7.5 & 0.99 & 9.7 & 3.5 & 30.2 & 5.5 & $\mathrm{D}$ \\
\hline 68W98(1) & 1.68 & 281 & 1.20 & 211 & 3.5 & 91 & 187 & 74 & 13.3 & 0.72 & 2.10 & 14.8 & 7.9 & 1.10 & 9.1 & 3.6 & 29.8 & 5.9 & $\mathrm{~L}$ \\
\hline 68W98(2) & 1.64 & nd & 1.14 & 229 & 3.6 & 89 & 180 & 72 & 13.2 & 0.69 & 2.00 & nd & 7.8 & 1.03 & 9.4 & 3.5 & 26.1 & 6.1 & $\mathrm{R}$ \\
\hline FALOR-2 & 1.67 & 280 & 1.15 & 212 & 3.7 & 91 & 174 & 69 & 13.3 & 0.69 & 2.10 & 13.9 & 7.8 & 1.01 & 9.0 & 3.6 & 29.7 & 6.2 & $\mathrm{D}$ \\
\hline Mean & 1.73 & 297 & 1.21 & 204 & 3.4 & 96 & 186 & 75 & 13.8 & 0.77 & 2.10 & 13.9 & 7.7 & 1.03 & 9.3 & 3.4 & 28.9 & 5.9 & \\
\hline \pm 1 s.d. & 0.06 & 12 & 0.04 & 12 & 0.3 & 6 & 10 & 5 & 0.6 & 0.07 & 0.08 & 0.4 & 0.3 & 0.04 & 0.3 & 0.2 & 1.3 & 0.3 & \\
\hline
\end{tabular}


graphic data and isotopic age determinations, represent a set of chronostratigraphic datum planes that provide age control and correlation among several depositional basins within the western conterminous United States for the age interval $\sim 2.85$ to $\sim 0.76 \mathrm{Ma}$. Within this $\sim 2-\mathrm{m} . \mathrm{y}$. period, correlation is possible by means of the tuff of Benton Hot Springs (2.89-2.81 Ma), the lower tuffs of the Badlands section $(\sim 2.7-\sim 2.6 \mathrm{Ma})$, the upper tuffs of the Badlands section ( 2.6- 2.2 Ma); the tuffs of Blind Spring Valley (2.22-2.14 Ma), the Huckleberry Ridge ash bed ( 2.06 Ma), the tuffs of Emigrant Pass ( 2.06- 1.92 $\mathrm{Ma})$, the lower tuffs of Glass Mountain (1.92-1.30 Ma), the upper tuffs of Glass Mountain ( 1.2- 0.8 Ma), and the Bishop ash bed ( 0.76 Ma)(fig. 21). Furthermore, presence of the tuffs of Blind Spring Valley, the Huckleberry Ridge ash bed, and the Bishop ash in both continental and marine sediments provides an important chronostratigraphic reference level that allows correlation and dating of uppermost Pliocene and Pleistocene marine and continental sections (Sarna-Wojcicki and others, 1987).
On the basis of their somewhat different glass composition, mineralogy, and significantly older age (2.89-2.81 $\mathrm{Ma}$ ), we consider the tuffs of Benton Hot Springs to represent a different eruptive episode from the tuffs of Blind Spring Valley (2.22 to $2.14 \mathrm{Ma}$ ), and from the lower tuffs of Glass Mountain at the Cowan Pumice Mine (1.92 to 1.86 Ma). The tuffs of Benton Hot Springs antedate eruptions of the tuffs of Blind Spring Valley by about 0.6 m.y., and eruptions from Glass Mountain by about 0.8 m.y., because the oldest K-Ar ages obtained on lava flows from the Glass Mountain source are about 2.1 Ma (Metz and Mahood, 1985). Judging by their coarse grain size, however, the eruptive source of the tuffs of Blind Spring Valley must have been close to, or at, the site of Glass Mountain; the lava flows and pyroclastic deposits exposed at Glass Mountain may cover older pyroclastic and flow rocks equivalent to the tuffs of Benton Hot Springs.

The tuffs of Blind Spring Valley are different from the underlying tuffs of Benton Hot Springs, and from the overlying lower tuffs of Glass Mountain, both with regard to chemi-

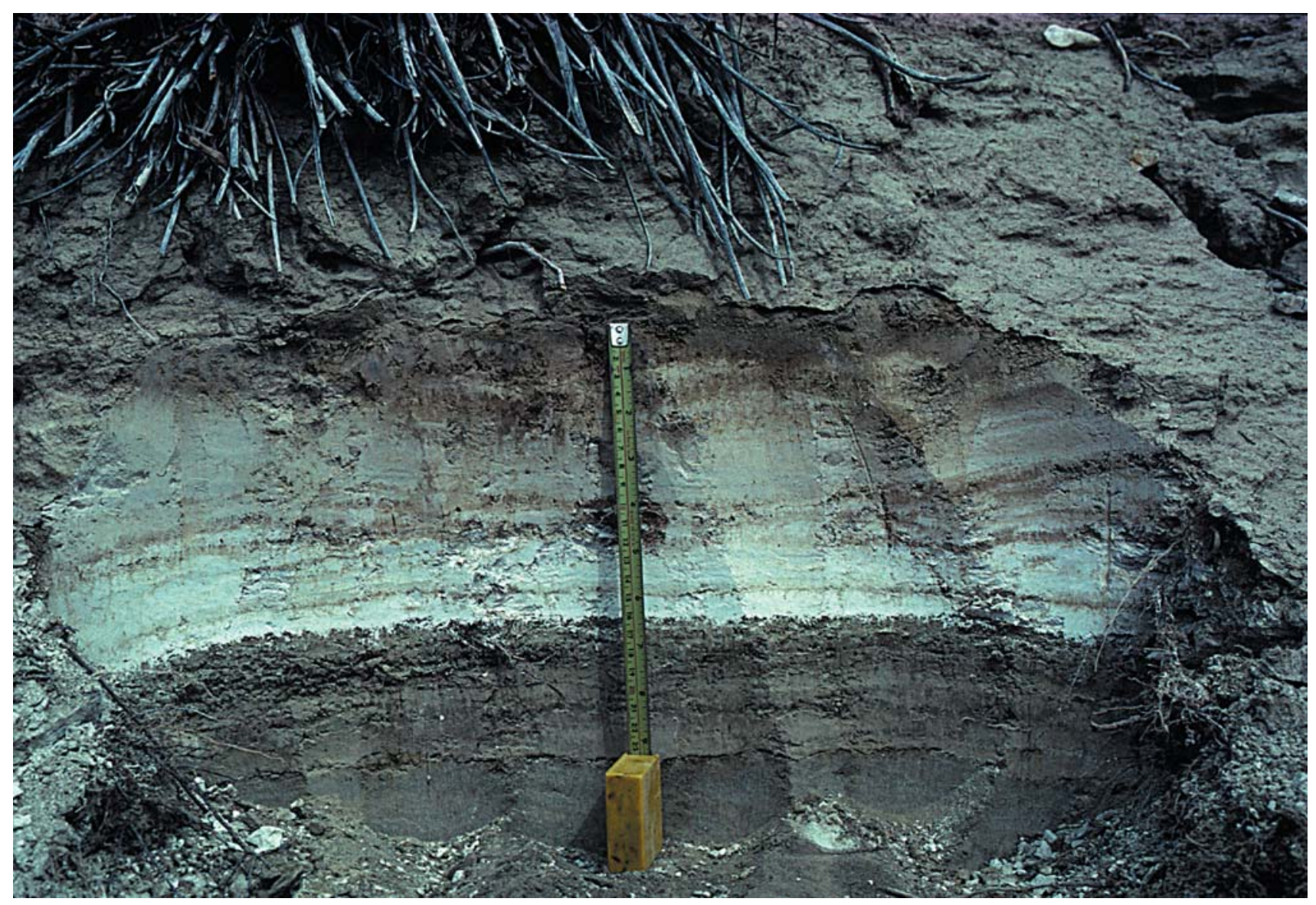

Figure 20. Tuff of Blind Spring Valley (light layer) in Beaver Basin, Utah (see Izett and others, 1988). About $14 \mathrm{~cm}$ thick, this layer stratigraphically underlies the Huckleberry Ridge ash bed by about $30 \mathrm{~m}$. This tephra layer most likely correlates with the thickest, coarsest unit at the Cowan Pumice Mine in Pit 6, TTC-22, (figs. 5, 6, 7), and also probably with the same unit in Pit 2 , TTC-18 (fig. 11). The basal, nearly pure white unit, about $1-1.5 \mathrm{~cm}$ thick, is most likely the initial airfall ash. Overlying this is a somewhat less pure, finely layered unit, about $3 \mathrm{~cm}$ thick, that represents repeated reworking of the tephra from the highlands tributary to the Beaver basin. Above this are additional fine layers and lenses, $\sim 10 \mathrm{~cm}$ altogether, of progressively less pure ash and ashy sediment, products of further reworking and redeposition of the ash from the adjoining countryside. 


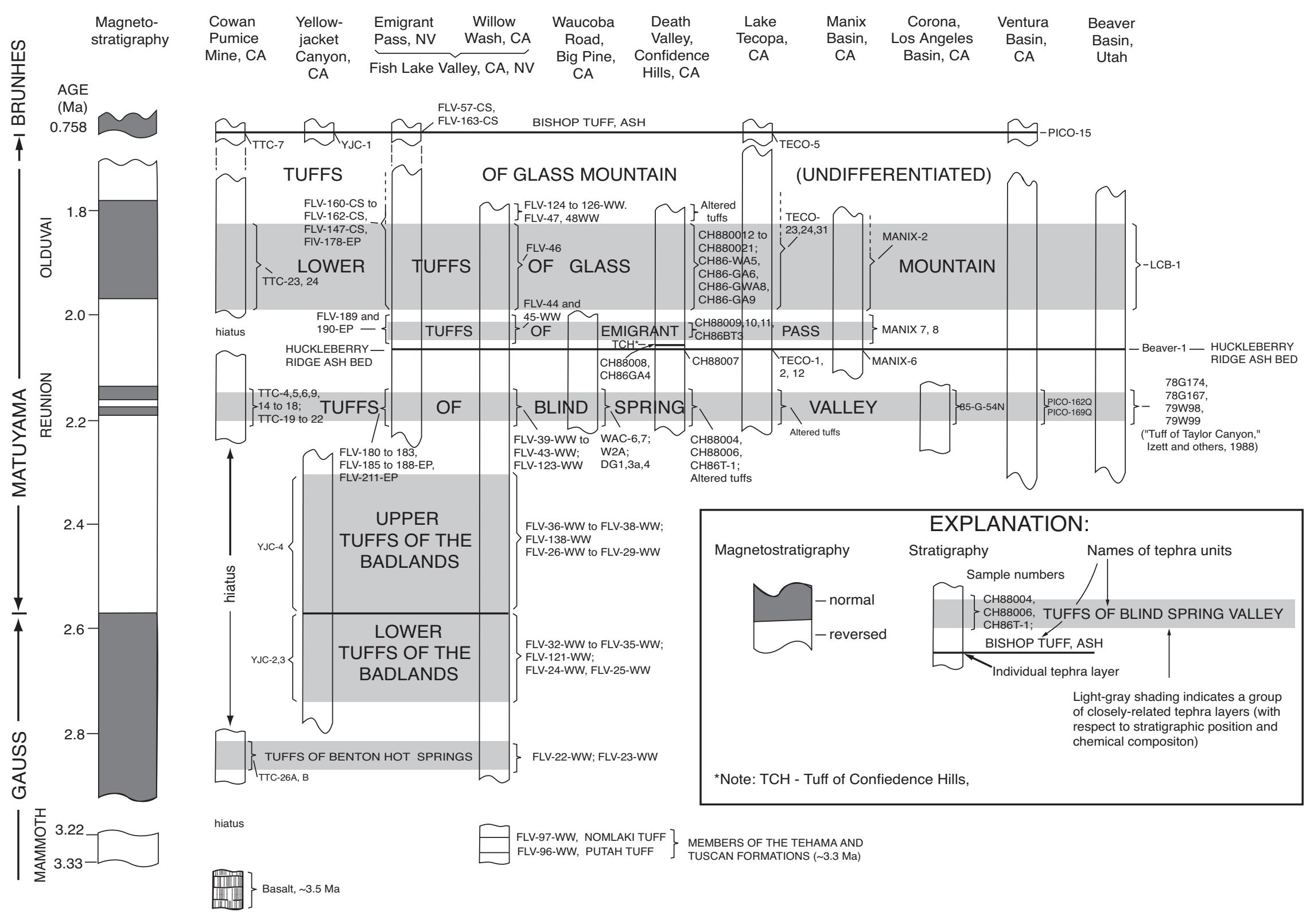

Figure 21. Magnetostratigraphy, chronology, and correlation of tuffs of Blind Spring Valley and related tephra layers for selected sites in southwestern United States. Light-shaded bands represent the presently-known age ranges of specific tuffs or tuff groups. Sample numbers (given by letter and number designations) are shown for each tuff or tuff group at each locality where they are identified. Solid horizontal lines mark individual tephra layers with precisely-determined ${ }^{40} \mathrm{Ar} /{ }^{39} \mathrm{Ar}$ ages: Bishop ash bed, $0.758 \pm 0.002 \mathrm{Ma}$ (Sarna-Wojcicki and Pringle, 1992; 0.774 $\pm 0.002 \mathrm{Ma}$, using monitor values of Samson and Alexander, 1987); Huckleberry Ridge ash bed, $2.054 \pm 0.007$ Ma (this report). TCH is tuff of Confidence Hills, reported at only one locality in this report. 
cal composition and isotopic age. Again, the coarse airfall pumice of the tuffs of Blind Spring Valley suggests that the source was nearby, and may have been the same as that of the later flows and tuffs of Glass Mountain, but extensive proximal exposures have not been found at Glass Mountain. Among the older rhyolitic lavas of Glass Mountain of Metz and Mahood (1991), their undated unit OF (CT75-5-6) may correlate with the tuffs of Blind Spring Valley, and their unit OG (200), dated 2.13 Ma, may correlate with the tuffs of Emigrant Pass that closely underlie and overlie the 2.05 -Ma Huckleberry Ridge ash bed, as suggested by the lower iron contents of these units compared to the other rhyolitic lavas of Glass Mountain of Metz and Mahood (1991). The tuffs of Benton Hot Springs, the tuffs of Blind Spring Valley, the tuffs of Emigrant Pass, and the tuffs of Glass Mountain all have chemical "family" resemblance to each other, but they are sufficiently different so that they can be distinguished from each other, and with ease from the Huckleberry Ridge ash bed, which lies within the tuffs of Emigrant Pass, above the tuffs of Blind Spring Valley, and below the older tuffs of Glass Mountian.

The Bishop Tuff at the top of the section at the Cowan Pumice Mine can also be distinguished chemically from tephra layers of Glass Mountain —although with difficulty and only by means of minor- and trace-element analyses - unless other criteria such as stratigraphic sequence, magnetostratigraphy, or direct isotopic age data, are available. Stratigraphic sequence and magnetostratigraphic orientation aid considerably in identification of these tephra layers.

The combined K-Ar ages of lavas erupted from Glass Mountain (Metz and Mahood, 1985), together with our ${ }^{40} \mathrm{Ar} /{ }^{39} \mathrm{Ar}$ laser-fusion ages of tephra layers from the Cowan Pumice Mine, appear to define perhaps as many as six eruptive episodes from the Glass Mountain area (fig. 22). The tuffs of Benton Hot Springs may define the first, and earliest period of activity, about 2.89 to $2.81 \mathrm{Ma}$, although the location of their eruptive source is not certain. A long period of volcanic activity, represented by the chemically related tuffs of the Badlands that are present in the sections at Willow Wash ( 2.81 to $2.22 \mathrm{Ma}$ ), is not represented at the Cowan Mine, and we infer that a hiatus representing $\sim 0.6$ m.y. exists at the latter site. Ages of the tuffs of Blind Spring Valley from the Cowan Pumice Mine, combined with chemical data on the composition of their volcanic glasses, suggest a range from about 2.22 to $2.14 \mathrm{Ma}$, representing an episode of activity of about 90 k.y. Judging by their coarse grain size and thickness gradients of their beds, these tephra layers were probably derived from the vicinity of Glass Mountain.

The four ages on tephra layers overlying the tuffs of Blind Spring Valley at Pit 6 at the Cowan Pumic Mine, the lower tuffs of Glass Mountain, coincide closely with those of the oldest lavas of Glass Mountain of Metz and Mahood (1985; 1991); together with the coherent chemical glass compositions, these ages define an eruptive episode about 180 k.y. in length, from 1.92 to $1.74 \mathrm{Ma}$. A dormant interval of about 140 k.y., from $\sim 1.74$ to $\sim 1.6 \mathrm{Ma}$, intervenes between this and the next period of activity, although the analytical errors associated with the K-Ar ages make its existence and duration uncertain. During the long, 400-k.y. period between $\sim 1.6$ and 1.2 $\mathrm{Ma}$, there appears to have been sporadic volcanic activity from the Glass Mountain source. Another dormant period of $\sim 100$ k.y. followed, from $\sim 1.2$ to $\sim 1.1 \mathrm{Ma}$; again, its duration is uncertain because of the large analytical error of the K-Ar ages on the associated flow rocks. This dormant period was followed by two episodes of apparently frequent and intense activity, the first from $\sim 1.1$ to $0.9 \mathrm{Ma}$, and the second from $\sim 0.82$ to $\sim 0.79 \mathrm{Ma}$, with an $\sim 80-\mathrm{k} . \mathrm{y}$. dormant period intervening between the two (fig. 22).

The chemical composition of these younger tuffs of Glass Mountain is very similar to that of the Bishop Tuff and ash, on the one hand, and to the lower tuffs of Glass Mountain, on the other. These several groups of tuffs are also all very similar petrographically to each other. Detailed stratigraphy, magnetostratigraphy, minor- and trace-element analyses, and isotopic ages are required to identify, correlate, and date the tuffs of Glass Mountain and the Bishop ash bed with any significant degree of confidence.

The chemical similarity of the tuffs of Glass Mountain and the Bishop Tuff/ash suggest that they are genetically related and have been erupted from the same magma chamber, or at least from a single, continuously evolving magma system (Smith, 1979; Metz and Mahood, 1991). The eruption of the Bishop Tuff can be considered as an isolated event in time (see fig. 22). Its age was determined most recently by the laser-fusion ${ }^{40} \mathrm{Ar} /{ }^{39} \mathrm{Ar}$ method (Sarna-Wojcicki and Pringle, 1992; Sarna-Wojcicki and others, 2000), and the associated analytical error is small compared to the analytical errors of our K-Ar ages and those of Metz and Mahood (1985). If the error were comparable to those of the dates on the younger Glass Mountain lavas ( 0.79 to $\sim 0.82 \mathrm{Ma}$ ), the Bishop Tuff could reasonably be viewed as the youngest eruption of the last eruptive episode from the combined Glass Mountain-Long Valley source. Moreover, resurgent volcanism from the Long Valley Caldera began shortly after eruption of the Bishop Tuff (Bailey and others, 1976); conventional K-Ar dates on the oldest post-Bishop Tuff eruptive episode range from 0.73 to $\sim 0.63 \mathrm{Ma}$. The entire 1.6-m.y. period, from the beginning of volcanic activity with the eruption of the tuffs of Blind Spring Valley at about 2.2 Ma, until about 0.6 Ma, can be thus viewed as a long period of alternating frequent and sporadic activity, interspersed with short periods of dormancy, from the combined Glass Mountain-Long Valley magmatic system. Part of the Glass Mountain volcanic field, some near-vent exposures of the lower Glass Mountain pyroclastic rocks, the tuffs of Blind Spring Valley, and possibly even the tuffs of Benton Hot Springs, may have subsided with the floor of the Long Valley caldera after eruption of the Bishop Tuff and now lie buried by a thick cover of younger volcanic deposits and alluvium.

The volume of volcanic and pyroclastic rocks erupted from the Glass Mountain source area during the 2-m.y. period from $\sim 2.8 \mathrm{Ma}$ to $\sim 0.8 \mathrm{Ma}$ is probably large but difficult to estimate because much of these deposits is buried by younger sediments and rocks or has been removed by erosion from uplands. The volume of the tuffs of Blind Spring Valley alone 
Age, $\mathrm{i}$ Millio Years before Prese $\mathrm{t}$

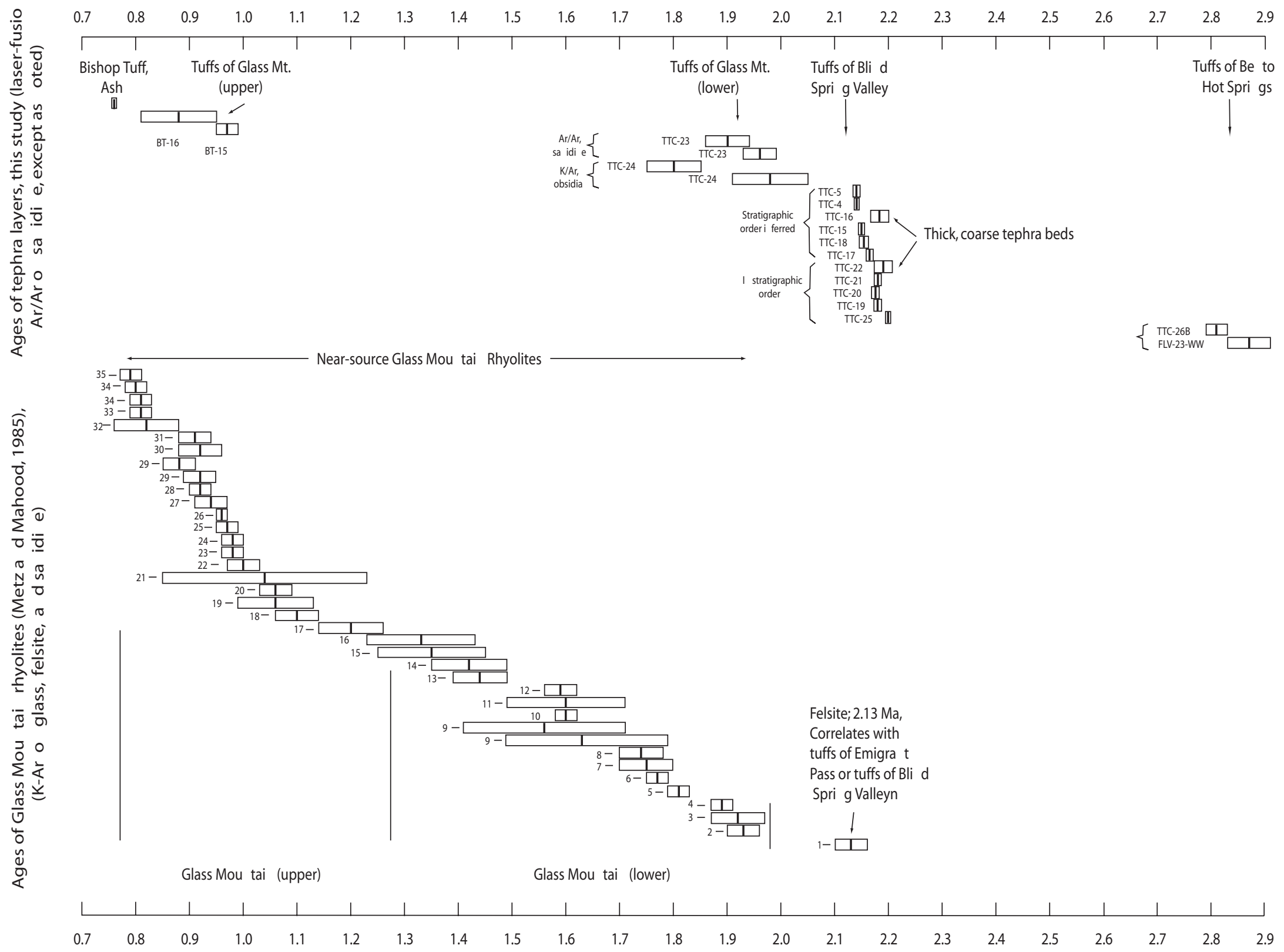

Figure 22. Chronology of tuffs of Blind Spring Valley and related tephra layers, based on ages reported here (top), compared to chronology (bottom) of near-source Glass Mountain rhyolites, reported in Metz and Mahood (1985). K/Ar is conventional potassium-argon age; LF 40Ar/39Ar is laser-fusion 40Ar/39Ar age. 
is estimated to be in the range of $\sim 67$ to $\sim 97 \mathrm{~km}^{3}$, using the method of Fierstein and Nathenson (1992)(J. E. Fierstein, written commun., 2002). The lower end of the above range is estimated from the volume of the coarsest and thickest of the tuffs of Blind Spring Valley (TTC-22 at Pit 6, Cowan Pumice Mine), about $4 \mathrm{~m}$ thick at a minimum distance of about $17 \mathrm{~km}$ from the eruptive source near Glass Mountain and about 1.0 $\mathrm{cm}$ thick at distal sites, including in Beaver Basin, Utah, 400 $\mathrm{km}$ to the east (figs. 1, 2, 5, 6, 7, 20). The total area covered by this unit is estimated to be $\sim 200,000 \mathrm{~km}^{2}$ (fig. 1). The upper end of the above estimate is based on an aggregate thickness of the tuffs of Blind Spring Valley of $\sim 6.5 \mathrm{~m}$, the $\sim 1.0-\mathrm{cm}$ thickness at distal sites, and the approximate $\sim 200,000-\mathrm{km}^{2}$ area covered by the tuffs of Blind spring Valley.

An additional volume of proximal rhyolite and ash-flow tuffs and proximal and distal tephra fall of the tuffs of Benton Hot Springs and tuffs of Glass Mountain, together with an unknown volume of coeval fall- and flow-rocks buried in the subsided part of Long Valley Caldera, may account for as much as another $\sim 50 \mathrm{~km}^{3}$. The total volume of material erupted from this source area in the time interval from $\sim 2.8$ to $\sim 0.8 \mathrm{Ma}$ may thus be as much as $\sim 150 \mathrm{~km}^{3}$. Volume of the subsequently erupted Bishop Tuff, $0.76 \mathrm{Ma}$, is estimated to be $\sim 500-550 \mathrm{~km}^{3}$ (Bailey and others, 1976).

Laser-fusion ${ }^{40} \mathrm{Ar} /{ }^{39} \mathrm{Ar}$ ages on sanidine that are presented here, in Sarna-Wojcicki and Pringle (1992), and in SarnaWojcicki and others (2000), are somewhat older than ages on the same volcanic units obtained by the conventional K-Ar method. This is probably because all radiogenic argon was not extracted from sanidine in conventional analyses. In ${ }^{40} \mathrm{Ar} /{ }^{39} \mathrm{Ar}$ analysis, it is not necessary to extract all the radiogenic argon, because only the ratios of Ar isotopes are measured, not the absolute amounts. This factor may result in some errors in the detailed interpretation of the volcanic history of Glass Mountain and Long Valley, such as durations of episodes of activity and dormancy, when $\mathrm{K}-\mathrm{Ar}$ and ${ }^{40} \mathrm{Ar} /{ }^{39} \mathrm{Ar}$ ages are compared, but most likely has little effect on the main outline of the chronology discussed here.

The stratigraphy in northeastern Fish Lake Valley and at Willow Wash, and the presence of multiple tephra layers in both sections that are missing at the Cowan Pumice Mine, suggest that hiatuses representing a considerable amount of time are present within the latter section (fig. 19). These observations also suggest that volcanism was much more continuous during the period from about 3.3 to $0.76 \mathrm{Ma}$ than is represented by volcanic units at the Cowan Pumice Mine and immediate vicinity. The Willow Wash section in particular contains many more tephra layers than are present elsewhere, which makes it a particularly good reference section for unravelling the late Cenozoic tephrostratigraphy of this region. This section may have been near the depositional center of a basin for all of Pliocene time, before it was deformed and uplifted sometime after $\sim 1.7 \mathrm{Ma}$. Although this section provides an excellent reference for determining the relative stratigraphic positions of tephra layers, and though much of the section is also suitable for magnetostratigraphy, attempts to date it directly by isotopic analysis of feldspars in the tephra layers by laser-fusion ${ }^{40} \mathrm{Ar} /{ }^{39} \mathrm{Ar}$ have had little success, owing to the presence of abundant detrital feldspars within the size range required for this type of analysis (appendix 3).

The combined chronostratigraphy developed for the stratigraphic section in Confidence Hills of Death Valley, based on data presented in Troxel and others (1986), Pluhar and others (1992), Beratran and Murray (1992), and in this report (fig. 18), provides new age estimates for three Reunion magnetostratigraphic events. The interpolated midpoint of the oldest of these is $2.22 \mathrm{Ma}$. The data of Pluhar and others (1992) indicate that this is a minor excursion that did not reach negative inclinations. The two younger Reunion events, which did reach complete reversal for some period of time, are bracketed between 2.18 and 2.17 Ma for the older (Reunion I), and between 2.16 and 2.14 Ma for the younger (Reunion II). The Huckleberry Ridge ash bed is stratigraphically well above these excusions, and must be younger, as proposed in Lanphere and others (2002).

Our laser-fusion ${ }^{40} \mathrm{Ar} /{ }^{39} \mathrm{Ar}$ date on sanidine separated from the Huckleberry Ridge ash bed is $2.063 \pm 0.007$ (weighted mean of 19 determinations, with error reported as standard error of the mean; Sarna-Wojcicki and Pringle, 1992; appendix 1). The analyses were on a proximal sample of the Huckleberry Ridge ash bed obtained from J.D. Obradovich of the U.S. Geological Survey, Denver. The above date is the same,

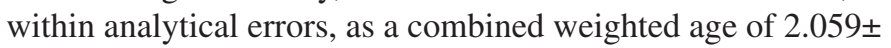
0.004 Ma obtained by Lanphere and others (2002) on this unit using the incremental-heating ${ }^{40} \mathrm{Ar} /{ }^{39} \mathrm{Ar}$ method. In figure 18 , for the purpose of comparing our age with the published ages of magnetostratigraphic boundaries, we converted the Huckleberry Ridge ash bed age to $2.09 \mathrm{Ma}$, using the more generally accepted, somewhat older values of the Taylor Creek Rhyolite (Rennie and others, 1998). The age estimates for the Reunion events are based on using the latter set of dates for interpolation.

Distal correlative layers of the tuffs of Blind Spring Valley are found in west-central Utah, western Nevada, and in California in Owens Valley, Death Valley, the Manix Basin, eastern Los Angeles Basin, and the Ventura Basin. As one would expect, we see a progressive "simplification" of the stratigraphy for the tuffs of Blind Spring Valley and related tephra layers with distance from the eruptive source area. Although the section at the Cowan Pumice Mine is incomplete owing to hiatuses, multiple thick, coarse units are present nearest to the source area. For any group of stratigraphically closely associated and chemically similar tephra layers in the proximal area, such as the tuffs of Blind Spring Valley, the thickness, grain size, and number of tephra layers generally decrease at successively more distal localities (figs. 8, $13,15,20)$. At the most distal sites, such as the Ventura or Beaver Basins for example, only one thin, fine-grained tephra layer is found that represents the tuffs of Blind Spring Valley. One likely explanation for this simplification is that eruptive episodes vary in character and magnitude: products of only the most voluminous and explosive eruptions are likely to be 
found at distal sites. Alternatively and in addition, multiple eruptions spaced closely in time can result in a complex of multiple layers deposited near the source, but fewer or only one layer at distal sites, owing to homogenization of tephra during transport by wind or subsequent reworking near the site of deposition, as has been observed for modern eruptions such as those from Mount St. Helens in 1980 (Sarna-Wojcicki and others, 1981; Shipley, 1983). Furthermore, variable wind directions with altitude and with time during an eruption or eruptive episode, will also tend to disperse tephra in different directions, resulting in a simplified and less complete stratigraphy at any single distal site (Sarna-Wojcicki and others, 1981; Shipley, 1983).

Our experience points toward an optimal strategy for developing regional chronostratigraphic frameworks using tephrochronology, isotopic data, and magnetostratigraphy. Depositional centers of long-lived sedimentary basins are the sites where the most complete records of sedimentation are preserved. It is within such depositional environments, where the energy for transport of sediments is at a minimum, that relatively complete records of volcanic ash falls from multiple eruptive sources are likely to be preserved. Such basins are often at some distance from plate margins or other loci of crustal instability such as mantle plumes or hot spots, where active tectonic deformation and associated volcanism occur. It is at or near volcanic source areas, however, that the best materials are available for direct isotopic analysis of tephra layers - coarse airfall pumice layers containing large mineral grains, and stratigraphically associated lava flows. Near source areas, thick, complete stratigraphic sections are rarely preserved because of rapid tectonic deformation and accompanying erosion or burial by both volcaniclastic sediments and lavas.

The optimal strategy, then, is to isotopically date tephra layers near volcanic sources, and to correlate them by chemical and petrographic criteria to sites where more complete, long-term stratigraphic records are available and where complementary age control can be obtained through magnetostratigraphy. In this manner, parts of stratigraphic sections can be bracketed by correlated ages of tephra layers, and the ages of intervening, undated tephra layers and other stratigraphic horizons can be estimated or determined by paleomagnetic orientation and interpolation.

Recent additional work in the region of Death Valley National Park (Knott, 1998; Knott and others, 1999; Machette and others, 2001; Sarna-Wojcick and others, 2001), and in Owens Lake (Smith and Bischoff, 1997; Sarna-Wojcicki and others, 1997), as well as new unpublished work (E. Kirby, A. Sarna-Wojcicki, M. Reheis, and D. Burbank, 2002) have already enlarged the present temporal/spatial framework that we present here. This framework (figs. 19 and 21) will undoubtedly be expanded and refined in the future, as new sites are found and additional tephra layers are analyzed.

\section{References}

Baedecker, P.A., and McKown, D.M., 1987, Instrumental neutron activation analysis of geochemical samples, in Baedecker, P.A. ed., Methods for geochemical analysis, U.S. Geological Survey Bulletin 1770, p. H1-H-14.

Bailey, R.A., Dalrymple, G. B., and Lanphere, M. A., 1976, Volcanism, structure, and geochronology of Long Valley Caldera, Mono County, California: Journal of Geophysical Research, v. 81, p. 725-744.

Beratran, K.K., and Murray, Bruce, 1992, Stratigraphy and depositional environments, southern Confidence Hills, Death Valley, California: San Bernardino County Museum Association Quartely, v. 39, no. 2, p. 7-11.

Borchardt, G.A., 1974, The SIMAN coefficient for similarity analysis: Classification Society Bulletin, v. 3, no. 2, p.1-8.

Borchardt, G.A., Aruscavage, P.J., and Millard, H.T., Jr., 1972, Correlation of Bishop Ash, a Pleistocene marker bed, using instrumental neutron activation analysis: Journal of Sedimentary Petrology, v. 42, no. 2, p. 301-306.

Bowman, H.R., Asaro, Frank, and Pearlman, Isidore, 1973, On the uniformity of composition in obsidians and evidence for magmatic mixing: Journal of Geology, v. 81, p. 312-327.

Christiansen, R.L., and Blank, H.R., Jr., 1972, Volcanic stratigraphy of the Quaternary rhyolite plateau in Yellowstone National Park: U.S. Geological Survey Professional Paper 729-B, 18 p.

Dalrymple, G. B., 1989, The GLM continuous laser system for ${ }^{40} \mathrm{Ar} /{ }^{39} \mathrm{Ar}$ dating; description and characteristics, in Shanks, W. C., III, and Criss, R. E., eds., New Frontiers in stable isotope research; laser probes, ion probes, and small-sample analysis: U.S. Geological Survey Bulletin 1890, p. 89-96.

Dalrymple, G.B., and Duffield, W.A., 1988, High precision ${ }^{40} \mathrm{Ar} /{ }^{39} \mathrm{Ar}$ dating of Oligocene rhyolites from the Mogollon-Datil volcanic field using a continuous laser system: Geophysical Research Letters, v. 15, p. 463-466.

Dalrymple, G.B., and Hirooka, Kimio, 1965, Variation of potassium, argon, and calculated age in a late Cenozoic basalt: Journal of Geophysical Research, v. 70, p. 52915296.

Dalrymple, G.B., and Lanphere, M.A., 1969, Potassium-argon dating: San Francisco, W.H. Freeman and Co., 258 p.

Fierstein, Judy, and Nathenson, Manuel, 1992, Another look at the calculation of fallout tephra volumes: Bulletin of Volcanology, v. 54, p. 156-167.

Gilbert, C.M., 1938, Welded tuff in eastern California: Geological Society of America Bulletin, v. 49, p. 1829-1862. 
Gilbert, C. M., Christensen, M. N., Al-Rawi, Yehya, and Lajoie, K. R., 1968, Structural and volcanic history of Mono Basin, California-Nevada: Geological Society of America Memoir 116, p. 275-329.

Hildreth, Wes, 1979, The Bishop Tuff; evidence for the origin of compositional zonation in silicic magma chambers, in Chapin, C.E., and Elston, W.E., eds., Ash-flow tuffs: Geological Society of America Special Paper 190, p. 43-75.

Holt, J.W., and Kirschvink, J.L., 1995, The upper Olduvai geomagnetic field reversal from Death Valley, California-a fold test of transitional directions: Earth and Planetary Sciences Letters, v. 133, p. 475-491.

Hopper, R.H., 1947, Geologic section from the Sierra Nevada to Death Valley, California: Geological Society of America Bulletin, v. 58, no. 5, p. 393-432.

Izett, G. A., 1981, Volcanic ash beds; recorders of upper Cenozoic silicic pyroclastic volcanism in the western United States: Journal of Geophysical Research, v. 86, no. B11, p. 10200-10222.

Izett, G. A., and Wilcox, R. E., 1982, Map showing localities and inferred distributions of the Huckleberry Ridge, Mesa Falls, and Lava Creek ash beds (Pearlette family ash beds) of Pliocene and Pleistocene age in the western United States and Canada: U.S. Geological Survey Miscellaneous Investigations Map I-1325, scale 1:4,000,000.

Izett, G.A., Naeser, C.W., and Obradovich, J.D., 1974, Fissiontrack age of zircons from an ash bed in the Pico Formation (Pliocene and Pleistocene) near Ventura, Calif.: Geological Society of America, Cordilleran Section, Annual Meeting, Abstracts with Program, p.197.

Izett, G.A., Obradovich, J.D., and Mehnert, H.H., 1982, The Bishop ash bed and some older closely related ash beds in California, Nevada, and Utah: U.S. Geological Survey Open-File Report 82-582, 60 p.

Izett, G. A., Obradovich, J. D., and Mehnert, H. H., 1988, The Bishop ash bed (middle Plieistocene) and some older (Pliocene and Pleistocene) chemically similar ash beds in California, Nevada, and Utah: U.S. Geological Survey Bulletin $1675,37 \mathrm{p}$.

Johnson, R.G., and King, B.-S.L., 1987, Energy-dispersive X-ray fluorescence spectrometry, in Baedecker, P.A., ed., Methods for geochemical analysis: U.S. Geological Survey Bulletin 1770, p. F1-F5.

Knott, J.R., 1998, Late Cenozoic tephrochronology, stratigraphy, geomorphology, and neotectonics of the western Black Mountains piedmont, Death Valley, California; Implications for the spatial and temporal evolution of the Death Valley Fault, Zone. Riverside, University of California, Ph.D. dissertation, $407 \mathrm{p}$.
Knott, J.R., Sarna-Wojcicki, A.M., Meyer, C.E., Tinsley, J.C., III, Wells, S.G., and Wan, Elmira, 1999, Late Cenozoic stratigraphy and tephrochronology of the western Black Mountains piedmont, Death Valley, California-Implications for the tectonic developement of Death Valley, in Wright, L.A., and Troxel, B.W., Cenozoic basins of the Death Valley Region: Geological Society of America Special Paper 333, p. 345-366.

Krauskopf, K. B., and Bateman, P. C., 1977, Geologic map of the Glass Mountain quadrangle, Mono County, California, and Mineral County, Nevada: U.S. Geological Survey Geologic Quadrangle Map GQ-1099, scale 1:62,500.

Lajoie, K.R., 1968, Late Quaternary stratigraphy and geologic history of Mono Basin, eastern California: Berkeley, University of California, Ph.D. dissertation, $271 \mathrm{p}$.

Lanphere, MA, Champion, D.E., Christiansen, R.L., Izett, G.A., and Obradovich, J.D., 2002, Revised ages for tuffs of the Yellowstone Plateau volcanic field; assignment of the Huckleberry Ridge Tuff to a new geomagnetic polarity event: Geological society of America Bulletin, v. 114, no. 5, p. 559-568.

LoBello, P., Feraud, G., Hall, C.M., York, D., Lavinia, P., and Bernat, M., 1987, ${ }^{40} \mathrm{Ar} /{ }^{39} \mathrm{Ar}$ step-heating and laser-fusion dating of a Quaternary pumice from Meschers, Massif Central, France - the defeat of xenocrystic contamination: Chemical Geology, v. 66, p. 61-71.

Machette, M.N., Steven, T.A., Cunningham, C.G., and Anderson, J.J., 1984, Geologic map of the Beaver Quadrangle, Beaver and Piute Counties, Utah: U.S. Geological Survey Miscellanous Investigations Map I-1520, scale 1:50,000.

Machette, M.N., Johnson, M.L., and Slate, J.L., 2001, Quaternary and late Pliocene geology of the Death Valley region-recent observations on tectonics, stratigraphy, and lake cycles, Pacific Cell, Friends of the Pleistocene Field Trip, Feb. 17-19: U.S. Geological Survey Open-File Report $01-51,246 \mathrm{p}$

McDougall, Ian, Brown, F.H., Cerling, T.E., and Hillhouse, 1992, A reappraisal of the geomagnetic polarity time scale to $4 \mathrm{Ma}$ using data from the Turkana basin, East Africa: Eos, Transactions of the American Geophysical Union, v. 73, no. 43, p. 629.

Metz, J. M., and Mahood, G. A., 1985, Precursors to the Bishop Tuff eruption-Glass Mountain, Long Valley, California: Journal of Geophysical Research, v. 90, no. B13, p. 11121-11126.

Metz, J.M., and Mahood, G.A., 1991, Development of the Long Valley, California, magma chamber recorded in precaldera rhyolite lavas of Glass Mountain: Contributions to Mineralogy and Petrology, v. 106, p. 379-397. 
Meyer, C.E., Sarna-Wojcicki, A.M., Hillhouse, J.W., Woodward, M.J., Slate, J.L., and Sorg, D.H., 1991, Fission-track age (400,000 yr) of the Rockland tephra, based on inclusion of zircon grains lacking fossil fission tracks: Quaternary Research, v. 35, p. 367-382.

Obradovich, J.D., and Izett, G.A., 1992, The geomagnetic polarity time scale (GPTS) and the astronomical time scale (ATS) now in near accord: Eos, Transactions of the American Geophysical Union, v. 73, no. 43, p. 630.

Parks, J.M., 1970, Fortran IV program for Q-mode cluster analysis on distance function with printed dendrogram: Kansas State Geological Survey and Kansas University, Lawrence, Computer Contribution 46, 32 p.

Pluhar, C.J., Holt, J.H., Kirschvink, J.L., Beratan, K.K., and Adams, R.W., 1992, Magnetostratigraphy of Plio-Pleistocene lake sediments in the Confidence Hills of southern Death Valley, California: San Bernardino County Museum Association Quarterly, v. 39, no. 2, p. 12-19.

Pringle, M.S., McWilliams, Michael, Houghton, B.F., Lanphere, M.A., and Wilson, C.J.N., 1992, ${ }^{40} \mathrm{Ar} /{ }^{39} \mathrm{Ar}$ dating of Quaternary feldspar; examples from the Taupo volcanic zone, New Zealand: Geology: v. 20, p. 531-534.

Reheis, M.C., 1992, Geologic map of late Cenozoic deposits and faults in parts of the Soldier Pass and Magruder Mountain 15' Quadrangles, Inyo and Mono Counties, California, and Esmeralda County, Nevada: U.S. Geological Survey Miscellanous Investigations Map I-2268, scale 1:24,000.

Reheis, M.C., Sarna-Wojcicki, A.M., Burbank, D.M., and Meyer, C.E., 1991, The late Cenozoic section at Willow Wash, west-central California - a tephrochronologic rosetta stone, in Reheis, M.C., Slate, J.L., Sawyer, T.L., SarnaWojcicki, A.M., Harden, J.W., Pendall, E.G., Gillespie, A.R., and Burbank, D.M., eds., Guidebook for Field Trip to Fish Lake Valley, California-Nevada: Friends of the Pleistocene, Pacific Cell, p. 46-66.

Reheis, M. C., Slate, J. L., Sarna-Wojcicki, A. M., and Meyer, C. E., 1993, A late Pliocene to middle Pleistocene pluvial lake in Fish Lake Valley, Nevada and California: Geological Society of America Bulletin, v. 105, p. 953-967.

Renne, P.R., Swisher, C.C., Deino, A.L., Karner, D.B., Owens, T.L. , and DePaolo, D.J., 1998, Intercalibration of standards, absolute ages and uncertainties in ${ }^{40} \mathrm{Ar} /{ }^{39} \mathrm{Ar}$ dating: Chemical Geology (Isotope Geoscience Section), v. 145, p. 117-152.

Samson, S. D., and Alexander, E. C., 1987, Calibration of the interlaboratory ${ }^{40} \mathrm{Ar} /{ }^{39} \mathrm{Ar}$ dating standard, MMhb-1: Chemical Geology (Isotope Geoscience Section), v. 66, p. 27-34.

Sarna-Wojcicki, A.M., 2000, Tephrochronology, in Noller, J.S., Sowers, J.M., and Lettis, W.R., eds., Quaternary geochronology: Washington, D.C., American Geophysical Union Reference Shelf 4, p. 357-377.
Sarna-Wojcicki, A.M., and Davis, J.O., 1991, Quaternary tephrochronology, in Morrison, R.B., ed., Quaternary nonglacial geology; conterminous U.S.: Boulder, Colorado, Geological Society of America, The Geology of North America, v. K-2, p. 93-116.

Sarna-Wojcicki, A. M., and Pringle, M. S., Jr, 1992, Laserfusion ${ }^{40} \mathrm{Ar} /{ }^{39} \mathrm{Ar}$ ages of the Tuff of Taylor Canyon and Bishop Tuff, E. California-W. Nevada: Eos, Transactions of the American Geophysical Union, v. 73, no. 43, p. 633.

Sarna-Wojcicki, A.M., Bowman, H.R., and Russell, P.C., 1979, Chemical correlation of some late Cenozoic tuffs of northern and central California by neutron activation analysis of glass and comparison with X-ray fluorescence analysis: U.S. Geological Survey Professional Paper 1147, 15 p.

Sarna-Wojcicki, A.M., Bowman, H.R., Meyer, C.E., Russell, P.C., Asaro, Frank, Michael, Helen, Rowe, J.J., Jr., Baedecker, P.A., and McCoy, Gail, 1980, Chemical analyses, correlations and ages of late Cenozoic tephra units of east-central and southern California: U.S. Geological Survey Open-File Report 80-231, 53 p.

Sarna-Wojcicki, A.M., Shipley, Susan, Waitt, R.B., Jr., Dzurisin, Daniel, and Wood, S.H., 1981, Areal distribution, thickness, mass, volume, and grain size of air-fall ash from the six major eruptions of 1980, in Lipman, P.W., and Mullineaux, D.R., eds., The 1980 eruptions of Mount St. Helens, Washington: U.S. Geological Survey Professional Paper 1250, p. 577-600.

Sarna-Wojcicki, A. M., Bowman, H.R., Meyer, C.E., Russell, P.C., Woodward, M.J., McCoy, Gail, Rowe, J.J., Jr., Baedecker, P.A., Asarao, Frank, and Michael, Helen, 1984, Chemical analyses, correlations, and ages of Upper Pliocene and Pleistocene ash layers of east-central and southern California: U.S. Geoloigcal Survey Professional Paper 1293, 40 p. 663.

Sarna-Wojcicki, A.M., Morrison, S.D., Meyer, C.E., and Hillhouse, J.W., 1987, Correlation of upper Cenozoic tephra layers between sediments of the western United States and eastern Pacific Ocean, and comparison with biostratigraphic and megnetostratigraphic data: Geological Society of America Bulletin, v. 98, p. 207-223.

Sarna-Wojcicki, A.M., Meyer, C.E., Wan, Elmira, and Soles, Stan, 1997, Age and correlation of tephra layers, position of the Matuyama-Brunhes chron boundary, and effects of Bishop ash eruption on Owens Lake, as determined from drill core OL-92, southeast California, in Smith, G.I., and Bischoff, J.L., eds., An 800,000-year paleoclimatic record from core OL-92, Owens Lake, southeast California: Geological Society of America Special Paper 317, p. 79-90.

Sarna-Wojcicki, A.M., Pringle, M.S., Jr., and Wijbrans, Jan, 2000, New ${ }^{40} \mathrm{Ar} /{ }^{39} \mathrm{Ar}$ age of the Bishop tuff from multiple sites and sediment rate calibration for the Matuyama-Brunhes Boundary: Journal of Geophysical Research, v. 105, no. B9, p. 21431-21443. 
Sarna-Wojcicki, A.M., Machette, M.N., Knott, J.R., Klinger, R.E., Fleck, R.J., Tinsley, J.C., III, Troxel, Bennie, Budahn, J.R., and Walker, J.P., 2001, Weaving a temporal and spatial framework for the late Neogene of Death Valley - correlation and dating of Pliocene and Quaternary units using tephrochronology, ${ }^{40} \mathrm{Ar}{ }^{\beta 9} \mathrm{Ar}$ dating, and other dating methods, in Machette, M.N., Johnson, M.L., and Slate, J.L., eds., Quaternary and late Pliocene geology of the Death Valley region-recent observations on tectonics, stratigraphy, and lake cycles, Pacific Cell, Friends of the Pleistocene Field Trip, Feb. 17-19: U.S. Geological Survey Open-File Report 01-51, p E121-E135.

Sheppard, R.A., and Gude, A.J., 3d, 1968, Distribution and genesis of authigenic silicate minerals in tuffs of Pleistocene Lake Tecopa, Inyo County, California: U.S. Geological Survey Professional Paper 597, 38p.

Shipley, Susan, 1983, Erosional modification of the downwind tephra lobe of the 18 May 1980 eruption of Mount St. Helens, Washington: Seattle, University of Washington, Masters thesis, $73 \mathrm{p}$.

Smith, R.L., 1979, Ash-flow magmatism, in Chapin, C.E., and Elston, W.E., eds., Ash-flow tuffs: Geological Society of America Special Paper 180, p. 5-27.

Smith, G.I., and Bischoff, J.L., eds., 1997, An 800,000-year paleoclimatic record from core OL-92, Owens Lake, southeast California: Geological Society of America Special Paper 317, 165 p.
Troxel, B.W., 1986, Pleistocene and Holocene deformation on a segmant of the southern Death Valley Fault Zone, California, in Troxel, B.W., ed., Quaternary tectonics of southern Death Valley, California: Friends of the Pleistocene, Pacific Cell, Field Trip Guide, p. 13-16.

Troxel, B.W., and Butler, P.R, 1986, Multiple Quaternary deformation, central part of the Confidence Hills, Death Valley, California; an example of folding along a strike-slip fault zone, in Troxel, B.W., ed., Quaternary tectonics of southern Death Valley, California: Friends of the Pleistocene, Pacific Cell, Field Trip Guide, p. 25-28.

Troxel, B.W., Sarna-Wojcicki, A.M., and Meyer, C.E., 1986, Ages, correlations, and sources of three ash beds in deformed Pleistocene beds, Confidence Hills, Death Valley, California, in Troxel, B.W., ed., Quaternary tectonics of southern Death Valley, California: Friends of the Pleistocene, Pacific Cell, Field Trip Guide, p. 29-30.

Wilson, C.J.N., and Hildreth, Wes, 1997, The Bishop Tuff; new insights from eruptive stratigraphy: Journal of Geology, v. 105 , p. 407-439.

York, D., Hall, C. M., Yanase, Y., Hanes, J. A., and Kenyon, W. J., 1981, ${ }^{40} \mathrm{Ar} /{ }^{39} \mathrm{Ar}$ dating of terrestrial minerals with a continuous laser: Geophysical Research Letters, v. 8, p. 1136-1138. 
Appendixes 1-3 
Appendix 1. Analytical data for laser-fusion ${ }^{40} \mathrm{Ar} /{ }^{39} \mathrm{Ar}$ age determinations of tephra layers. Individual dates followed by an asterisk $\left({ }^{*}\right)$ are not included in the average weighted mean age for the group because of outliers in one or more of the critical parameters: age, standard deviation, ${ }^{40} \mathrm{Ar} /{ }^{39} \mathrm{Ar}$, or ${ }^{40} \mathrm{Ar}{ }^{*}(\mathrm{~mol}) . \mathrm{The}^{\mathrm{w}} \mathrm{ighted} \mathrm{mean}, \mathrm{weighted}$ standard deviation $( \pm 1 \sigma)$, and weighted standard error of the mean (SEM), are given for those groups where the mean standard weighted deviates (MSWD) are equal to or less than one. For those groups where the MSWD is greater than one, the weighted standard deviation and SEM are calculated for a MSWD forced to one. Analysts: Malcolm Pringle for experiments no. $92 Z$ (1992) and Robert Fleck for experiments $94 Z$ (1994), U.S. Geological Survey, Menlo Park, Ar/Ar Laboratory.

Cowan Pumice Mine Locality, Blind Spring Valley

Pit 6, and underlying section (in stratigraphic order, from youngest at top)

\begin{tabular}{|c|c|c|c|c|c|c|c|c|c|c|c|}
\hline \multicolumn{12}{|c|}{ Tuffs of Glass Mountain (lower), TTC-23 } \\
\hline $\begin{array}{l}\text { Irradiation No.: } \\
\text { Experiment No. }\end{array}$ & $\begin{array}{l}\text { CIV-A-23 } \\
\text { Sample }\end{array}$ & $\begin{array}{c}\mathrm{J}=0.0003835 \\
\text { Material }\end{array}$ & No. of grains & ${ }^{40} \mathrm{Ar} *(\mathrm{~mol})$ & $\mathrm{K} / \mathrm{Ca}$ & ${ }^{40} \mathrm{Ar} *(\%)$ & ${ }^{40} \mathrm{Ar} /{ }^{39} \mathrm{Ar}$ & ${ }^{37} \mathrm{Ar} /{ }^{39} \mathrm{Ar}$ & ${ }^{36} \mathrm{Ar} /{ }^{39} \mathrm{Ar}$ & Age & \pm 1 s.d. \\
\hline $92 \mathrm{Z} 0563 \mathrm{~A}$ & TTC-23 (1) & sanidine & 5 & 0.000 & 33.646 & 92.043 & 3.043 & 0.015 & 0.001 & 1.936 & 0.030 \\
\hline 92Z0569A & TTC-23 (2) & “ & $10+$ & 0.000 & 32.724 & 76.679 & 3.579 & 0.015 & $\begin{array}{c}0.003 \\
\text { Weighted Mean } \\
\pm 1 \text { SEM } \\
\text { MSWD }\end{array}$ & $\begin{array}{l}1.898 \\
\mathbf{1 . 9 2 2} \\
\mathbf{0 . 0 2 4} \\
0.596\end{array}$ & $\begin{array}{l}0.039 \\
\mathbf{0 . 0 3 4}\end{array}$ \\
\hline
\end{tabular}

\begin{tabular}{|c|c|c|c|c|c|c|c|c|c|c|c|}
\hline \multicolumn{12}{|c|}{ Tuffs of Blind Spring Valley, TTC-22 } \\
\hline $\begin{array}{l}\text { Irradiation No.: } \\
\text { Experiment No. }\end{array}$ & $\begin{array}{l}\text { CIV-A-22 } \\
\text { Sample }\end{array}$ & $\begin{array}{c}\mathrm{J}=0.000385 \\
\text { Material }\end{array}$ & No. of grains & ${ }^{40} \mathrm{Ar} *(\mathrm{~mol})$ & $\mathrm{K} / \mathrm{Ca}$ & ${ }^{40} \mathrm{Ar}^{*}(\%)$ & ${ }^{40} \mathrm{Ar} /{ }^{39} \mathrm{Ar}$ & ${ }^{37} \mathrm{Ar} /{ }^{39} \mathrm{Ar}$ & ${ }^{36} \mathrm{Ar} /{ }^{39} \mathrm{Ar}$ & Age & \pm 1 s.d. \\
\hline $92 \mathrm{Z} 0572 \mathrm{~A}$ & TTC-22 (1) & sanidine & 1 & 0.000 & 50.261 & 89.101 & 3.496 & 0.001 & 0.001 & 2.162 & 0.020 \\
\hline 92Z0572B & TTC-22 (2) & “ & 4 & 0.000 & 130.120 & 91.937 & 3.399 & 0.004 & 0.001 & 2.169 & 0.018 \\
\hline $92 \mathrm{Z} 0572 \mathrm{C}$ & TTC-22 (3) & “ & 4 & 0.000 & 34.017 & 84.015 & 3.872 & 0.014 & 0.002 & 2.258 & 0.022 \\
\hline $92 \mathrm{Z} 0572 \mathrm{D}$ & TTC-22 (4) & “ & $\sim 4$ & 0.000 & 13.099 & 82.768 & 3.773 & 0.037 & 0.002 & 2.168 & 0.022 \\
\hline $92 \mathrm{Z} 0572 \mathrm{E}$ & TTC-22 (5) & “ & 4 & 0.000 & 16.854 & 85.043 & 3.808 & 0.029 & 0.002 & 2.248 & 0.024 \\
\hline \multirow[t]{4}{*}{$92 \mathrm{Z} 0572 \mathrm{~F}$} & TTC-22 (6) & “ & 4 & 0.000 & 15.902 & 80.262 & 3.898 & 0.031 & 0.003 & 2.172 & 0.020 \\
\hline & & & & & & & & & Weighted Mean & 2.191 & 0.042 \\
\hline & & & & & & & & & \pm 1 SEM & 0.017 & \\
\hline & & & & & & & & & MSWD & 4.121 & \\
\hline
\end{tabular}

Tuffs of Blind Spring Valley, TTC-21

\begin{tabular}{|c|c|c|c|c|c|c|c|c|c|c|c|}
\hline $\begin{array}{l}\text { Irradiation No.: } \\
\text { Experiment No. }\end{array}$ & $\begin{array}{l}\text { CIV-A-19 } \\
\text { Sample }\end{array}$ & $\begin{array}{c}\mathrm{J}=0.0003895 \\
\text { Material }\end{array}$ & No. of grains & ${ }^{40} \mathrm{Ar}^{*}(\mathrm{~mol})$ & $\mathrm{K} / \mathrm{Ca}$ & ${ }^{40} \mathrm{Ar} *(\%)$ & ${ }^{40} \mathrm{Ar} /{ }^{39} \mathrm{Ar}$ & ${ }^{37} \mathrm{Ar} /{ }^{39} \mathrm{Ar}$ & ${ }^{36} \mathrm{Ar} /{ }^{39} \mathrm{Ar}$ & Age & \pm 1 s.d. \\
\hline 92Z0589A & TTC-21 (1) & sanidine & $?$ & 0.000 & 31.482 & 92.871 & 3.321 & 0.016 & 0.001 & 2.166 & 0.015 \\
\hline 92Z0589B & TTC-21 (2) & “ & $?$ & 0.000 & 20.729 & 86.718 & 3.598 & 0.024 & 0.002 & 2.191 & 0.018 \\
\hline $92 \mathrm{Z} 0571 \mathrm{C}$ & TTC-21 (3) & “ & 2 & 0.000 & 40.782 & 90.442 & 3.467 & 0.012 & 0.001 & 2.202 & 0.018 \\
\hline 92Z0571D & TTC-21 (4) & “ & 2 & 0.000 & 29.079 & 91.639 & 3.384 & 0.017 & 0.000 & 2.178 & 0.018 \\
\hline $92 \mathrm{Z} 0571 \mathrm{E}$ & TTC-21 (5) & “ & 2 & 0.000 & 52.575 & 94.293 & 3.307 & 0.009 & 0.001 & 2.190 & 0.016 \\
\hline $92 \mathrm{Z} 0571 \mathrm{~F}$ & TTC-21 (6) & “ & 2 & 0.000 & 134.598 & 90.140 & 3.509 & 0.004 & 0.001 & 2.221 & 0.021 \\
\hline \multirow[t]{4}{*}{$92 \mathrm{Z} 0571 \mathrm{G}$} & TTc-21 (7) & “ & 2 & 0.000 & 44.831 & 87.161 & 3.541 & 0.011 & 0.002 & 2.167 & 0.020 \\
\hline & & & & & & & & & Weighted Mean & 2.187 & 0.187 \\
\hline & & & & & & & & & \pm 1 SEM & 0.007 & \\
\hline & & & & & & & & & MSWD & 1.161 & \\
\hline
\end{tabular}




\begin{tabular}{|c|c|c|c|c|c|c|c|c|c|c|c|}
\hline \multicolumn{12}{|c|}{ Tuffs of Blind Spring Valley, TTC-20 } \\
\hline $\begin{array}{l}\text { Irradiation No.: } \\
\text { Experiment No. }\end{array}$ & $\begin{array}{l}\text { CIV-A-18 } \\
\text { Sample }\end{array}$ & $\begin{array}{c}\mathrm{J}=0.000391 \\
\text { Material }\end{array}$ & No. of grains & ${ }^{40} \mathrm{Ar}^{*}(\mathrm{~mol})$ & $\mathrm{K} / \mathrm{Ca}$ & ${ }^{40} \mathrm{Ar} *(\%)$ & ${ }^{40} \mathrm{Ar} /{ }^{39} \mathrm{Ar}$ & ${ }^{37} \mathrm{Ar} /{ }^{39} \mathrm{Ar}$ & ${ }^{36} \mathrm{Ar} /{ }^{39} \mathrm{Ar}$ & Age & \pm 1 s.d. \\
\hline $92 \mathrm{Z} 0568 \mathrm{~B}$ & TTC-20 (2) & “ & 1 & 0.000 & 78.599 & 91.135 & 3.385 & 0.006 & 0.001 & 2.174 & 0.020 \\
\hline $92 \mathrm{Z} 0568 \mathrm{C}$ & TTC-20 (3) & “ & 1 & 0.000 & 32.913 & 78.673 & 3.949 & 0.015 & 0.003 & 2.190 & 0.019 \\
\hline $92 \mathrm{Z} 0568 \mathrm{D}$ & TTC-20 (4) & “ & 3 & 0.000 & 29.763 & 94.590 & 3.244 & 0.016 & 0.001 & 2.163 & 0.018 \\
\hline $92 \mathrm{Z} 0568 \mathrm{E}$ & TTC-20 (5) & “ & 3 & 0.000 & 27.880 & 85.527 & 3.628 & 0.018 & 0.002 & 2.188 & 0.019 \\
\hline $92 \mathrm{Z} 0568 \mathrm{~F}$ & TTC-20 (6) & “ & 3 & 0.000 & 81.525 & 83.004 & 3.711 & 0.006 & 0.002 & 2.171 & 0.021 \\
\hline & & & & & & & & & Weighted Mean & 2.176 & 0.019 \\
\hline & & & & & & & & & \pm 1 SEM & 0.008 & \\
\hline & & & & & & & & & MSWD & 0.322 & \\
\hline \multicolumn{12}{|c|}{ Tuffs of Blind Spring Valley (basal unit in Pit 6) } \\
\hline Irradiation No.: & CIV-A-17 & $\mathrm{J}=0.0003925$ & & & & & & & & & \\
\hline Experiment No. & Sample & Material & No. of grains & ${ }^{40} \mathrm{Ar} *(\mathrm{~mol})$ & $\mathrm{K} / \mathrm{Ca}$ & ${ }^{40} \mathrm{Ar} *(\%)$ & ${ }^{40} \mathrm{Ar} /{ }^{39} \mathrm{Ar}$ & ${ }^{37} \mathrm{Ar} /{ }^{39} \mathrm{Ar}$ & ${ }^{36} \mathrm{Ar} /{ }^{39} \mathrm{Ar}$ & Age & \pm 1 s.d. \\
\hline $92 \mathrm{Z} 0567 \mathrm{~A}$ & TTC-19 (1) & sanidine? & 2 & 0.000 & 2.857 & 85.450 & 3.549 & 0.171 & 0.002 & 2.146 & 0.030 \\
\hline 92Z0567B & TTC-19 (2) & sanidine & 2 & 0.000 & 47.718 & 93.102 & 3.277 & 0.010 & 0.001 & 2.159 & 0.019 \\
\hline $92 \mathrm{Z} 0567 \mathrm{C}$ & TTC-19 (3) & “ & 2 & 0.000 & 24.369 & 91.074 & 3.345 & 0.020 & 0.001 & 2.156 & 0.023 \\
\hline 92Z0567D & TTC-19 (4) & “ & 2 & 0.000 & 37.767 & 85.052 & 3.609 & 0.013 & 0.002 & 2.172 & 0.029 \\
\hline $92 Z 0567 \mathrm{E}$ & TTC-19 (5) & “ & 2 & 0.000 & 45.777 & 92.764 & 3.352 & 0.011 & 0.001 & 2.201 & 0.024 \\
\hline $92 \mathrm{Z} 0567 \mathrm{~F}$ & TTC-19 (6) & “ & 2 & 0.000 & 31.145 & 90.799 & 3.388 & 0.016 & 0.001 & 2.177 & 0.025 \\
\hline 92Z0590A & TTC-19 (7) & “ & $?$ & 0.000 & 31.010 & 92.693 & 3.344 & 0.016 & 0.001 & 2.193 & 0.016 \\
\hline 92Z0590B & TTC-19 (8) & “ & $?$ & 0.000 & 29.524 & 92.625 & 3.331 & 0.017 & 0.001 & 2.183 & 0.017 \\
\hline & & & & & & & & & Weighted Mean & 2.177 & 0.021 \\
\hline & & & & & & & & & $\pm 1 \mathrm{SEM}$ & 0.008 & \\
\hline & & & & & & & & & MSWD & 0.696 & \\
\hline \multicolumn{12}{|c|}{ Tuffs of Blind Spring Valley, TTC-25 (tuff in tuffaceous arkosic sediments stratigraphically beneath TTC-19), } \\
\hline Irradiation No.: & CIV-A-24 & $\mathrm{J}=0.000382$ & & & & & & & & & \\
\hline Experiment No. & Sample & Material & No. of grains & ${ }^{40} \mathrm{Ar} *(\mathrm{~mol})$ & $\mathrm{K} / \mathrm{Ca}$ & ${ }^{40} \mathrm{Ar} *(\%)$ & ${ }^{40} \mathrm{Ar} /{ }^{39} \mathrm{Ar}$ & ${ }^{37} \mathrm{Ar} /{ }^{39} \mathrm{Ar}$ & ${ }^{36} \mathrm{Ar} /{ }^{39} \mathrm{Ar}$ & Age & \pm 1 s.d. \\
\hline $92 \mathrm{Z} 0573 \mathrm{~A}$ & TTC-25 (1) & sanidine & 1 & 0.000 & 77.845 & 96.256 & 3.355 & 0.006 & 0.000 & 2.224 & 0.016 \\
\hline 92Z0573B & TTC-25 (1) & “ & 1 & 0.000 & 34.440 & 92.525 & 3.494 & 0.014 & 0.001 & 2.227 & 0.021 \\
\hline 92Z0573C & TTC-25 (1) & “ & 1 & 0.000 & 40.293 & 95.989 & 3.374 & 0.012 & 0.001 & 2.230 & 0.015 \\
\hline 92Z0573D & TTC-25 (1) & “ & 3 & 0.000 & 29.364 & 90.565 & 3.541 & 0.017 & 0.001 & 2.209 & 0.016 \\
\hline 92Z0573E & TTC-25 (1) & “ & 3 & 0.000 & 61.804 & 93.065 & 3.471 & 0.008 & 0.001 & 2.225 & 0.017 \\
\hline $92 \mathrm{Z} 0573 \mathrm{~F}$ & TTC-25 (1) & “ & 3 & 0.000 & 10.050 & 88.379 & 3.582 & 0.049 & 0.001 & 2.180 & 0.022 \\
\hline 92Z0588A & TTC-25 (1) & “ & $?$ & 0.000 & 20.685 & 88.717 & 3.642 & 0.024 & 0.001 & 2.225 & 0.017 \\
\hline \multirow[t]{4}{*}{ 92Z0588B } & TTC-25 (1) & “ & $?$ & 0.000 & 25.791 & 93.937 & 3.427 & 0.019 & 0.001 & 2.217 & 0.016 \\
\hline & & & & & & & & & Weighted Mean & 2.219 & 0.017 \\
\hline & & & & & & & & & $\pm 1 \mathrm{SEM}$ & 0.006 & \\
\hline & & & & & & & & & MSWD & 0.064 & \\
\hline
\end{tabular}




\begin{tabular}{|c|c|c|c|c|c|c|c|c|c|c|c|}
\hline \multicolumn{12}{|c|}{ Tuffs of Benton Hot Springs, TTC-26B (tuff in arkosic tuffaceous sediments stratigraphically below TTC-25) } \\
\hline $\begin{array}{l}\text { Irradiation No.: } \\
\text { Experiment No. }\end{array}$ & $\begin{array}{l}\text { CIV-A-25 } \\
\text { Sample }\end{array}$ & $\begin{array}{c}\mathrm{J}=0.000381 \\
\text { Material }\end{array}$ & No. of grains & ${ }^{40} \mathrm{Ar} *(\mathrm{~mol})$ & $\mathrm{K} / \mathrm{Ca}$ & ${ }^{40} \mathrm{Ar} *(\%)$ & ${ }^{40} \mathrm{Ar} /{ }^{39} \mathrm{Ar}$ & ${ }^{37} \mathrm{Ar} /{ }^{39} \mathrm{Ar}$ & ${ }^{36} \mathrm{Ar} /{ }^{39} \mathrm{Ar}$ & Age & \pm 1 s.d. \\
\hline 92Z0587A & TTC-26B (1) & plagioclase & 10 to 15 & 0.000 & 0.407 & 62.218 & 6.346 & 1.204 & 0.008 & 2.714 & 0.053 \\
\hline 92Z0587B & TTC-26B (2) & " & $8+$ & 0.000 & 0.342 & 53.785 & 7.521 & 1.433 & 0.012 & 2.781 & 0.080 \\
\hline 92Z0587C & TTC-26B (3) & “ & $?$ & 0.000 & 0.369 & 67.709 & 6.134 & 1.326 & 0.007 & 2.855 & 0.037 \\
\hline 92Z0587D & TTC-26B (4) & “ & 1 & 0.000 & 0.422 & 80.235 & 5.075 & 1.160 & 0.004 & 2.798 & 0.033 \\
\hline 92Z0574A & TTC-26B (5) & “ & 1 & 0.000 & 0.491 & 73.471 & 5.718 & 0.997 & 0.005 & 2.887 & 0.104 \\
\hline 92Z0574B & TTC-26B (6) & “ & 1 & 0.000 & 0.417 & 83.598 & 5.036 & 1.174 & 0.003 & 2.893 & 0.135 \\
\hline $92 \mathrm{Z} 0574 \mathrm{C}$ & TTC-26B (7) & “ & 1 & 0.000 & 0.251 & 57.858 & 7.133 & 1.949 & 0.011 & 2.838 & 0.178 \\
\hline 92Z0574D & TTC-26B (8) & “ & 1 & 0.000 & 0.350 & 77.251 & 5.707 & 1.397 & 0.005 & 3.030 & 0.133 \\
\hline 92Z0574E & TTC-26B (9) & “ & 4 & 0.000 & 0.310 & 72.903 & 5.811 & 1.584 & 0.006 & 2.913 & 0.121 \\
\hline \multirow[t]{4}{*}{ 92Z0574F } & TTC-26B (10) & “ & 4 & 0.000 & 0.431 & 54.578 & 7.059 & 1.135 & 0.011 & 2.648 & 0.090 \\
\hline & & & & & & & & & Weighted Mean & 2.808 & 0.074 \\
\hline & & & & & & & & & $\pm 1 \mathrm{SEM}$ & 0.023 & \\
\hline & & & & & & & & & MSWD & 1.408 & \\
\hline
\end{tabular}

Pit 2 (Fault Pit)

Tuffs of Blind Spring Valley, TTC-18

\begin{tabular}{|c|c|c|c|c|c|c|c|c|c|c|c|}
\hline $\begin{array}{l}\text { Irradiation No.: } \\
\text { Experiment No. }\end{array}$ & $\begin{array}{l}\text { CIV-A-16 } \\
\text { Sample }\end{array}$ & $\begin{array}{c}\mathrm{J}=0.000394 \\
\text { Material }\end{array}$ & No. of grains & ${ }^{40} \mathrm{Ar}^{*}(\mathrm{~mol})$ & $\mathrm{K} / \mathrm{Ca}$ & ${ }^{40} \mathrm{Ar} *(\%)$ & ${ }^{40} \mathrm{Ar} /{ }^{39} \mathrm{Ar}$ & ${ }^{37} \mathrm{Ar} /{ }^{39} \mathrm{Ar}$ & ${ }^{36} \mathrm{Ar} /{ }^{39} \mathrm{Ar}$ & Age & \pm 1 s.d. \\
\hline 92Z0566A & TTC-18 (1) & sanidine & $(0.857 \mathrm{mg})$ & 0.000 & 50.467 & 84.633 & 3.370 & 0.001 & 0.002 & $2.0258^{*}$ & 0.018 \\
\hline 92Z0566B & TTC-18 (2) & “ & $(0.890 \mathrm{mg})$ & 0.000 & 36.207 & 88.271 & 3.420 & 0.014 & 0.001 & 2.144 & 0.017 \\
\hline 92Z0566C & TTC-18 (3) & “ & $(1.042 \mathrm{mg})$ & 0.000 & 18.274 & 97.413 & 3.172 & 0.027 & 0.000 & 2.195 & 0.026 \\
\hline 92Z0566D & TTC-18 (4) & “ & $(1.557 \mathrm{mg})$ & 0.000 & 47.910 & 81.512 & 3.684 & 0.010 & 0.002 & 2.133 & 0.017 \\
\hline $92 \mathrm{Z} 0566 \mathrm{E}$ & TTC-18 (5) & “ & $(1.522 \mathrm{mg})$ & 0.000 & 49.546 & 86.336 & 3.506 & 0.001 & 0.002 & 2.150 & 0.016 \\
\hline \multirow[t]{4}{*}{$92 \mathrm{Z} 0566 \mathrm{~F}$} & TTC-18 (6) & “ & $(2.050 \mathrm{mg})$ & 0.000 & 44.726 & 87.611 & 3.494 & 0.011 & 0.001 & 2.174 & 0.015 \\
\hline & & & & & & & & & Weighted Mean & 2.156 & 0.021 \\
\hline & & & & & & & & & $\pm 1 \mathrm{SEM}$ & 0.001 & \\
\hline & & & & & & & & & MSWD & 1.539 & \\
\hline
\end{tabular}

\section{Pit 3 (West Pit)}

Tuffs of Blind Spring Valley, TTC-5

\begin{tabular}{|c|c|c|c|c|c|c|c|c|c|c|c|}
\hline $\begin{array}{l}\text { Irradiation No.: } \\
\text { Experiment No. }\end{array}$ & $\begin{array}{l}\text { CIV-A-7 } \\
\text { Sample }\end{array}$ & $\begin{array}{c}\mathrm{J}=0.000405 \\
\text { Material }\end{array}$ & No. of grains & ${ }^{40} \mathrm{Ar} *(\mathrm{~mol})$ & $\mathrm{K} / \mathrm{Ca}$ & ${ }^{40} \mathrm{Ar} *(\%)$ & ${ }^{40} \mathrm{Ar} /{ }^{39} \mathrm{Ar}$ & ${ }^{37} \mathrm{Ar} /{ }^{39} \mathrm{Ar}$ & ${ }^{36} \mathrm{Ar} /{ }^{39} \mathrm{Ar}$ & Age & \pm 1 s.d. \\
\hline 92Z0560A & TTC-5 (1) & sanidine & 1 & 0.000 & 51.486 & 87.390 & 3.377 & 0.001 & 0.001 & 2.155 & 0.016 \\
\hline 92Z0560B & TTC-5 (2) & “ & 1 & 0.000 & 31.229 & 92.611 & 3.147 & 0.016 & 0.001 & 2.128 & 0.016 \\
\hline 92Z0560C & TTC-5 (3) & “ & 1 & 0.000 & 48.394 & 89.479 & 3.260 & 0.010 & 0.001 & 2.130 & 0.018 \\
\hline 92Z0560D & TTC-5 (4) & “ & 1 & 0.000 & 37.253 & 92.605 & 3.178 & 0.013 & 0.001 & 2.149 & 0.019 \\
\hline $92 \mathrm{Z} 0560 \mathrm{E}$ & TTC-5 (4) & “ & 3 & 0.000 & 41.258 & 90.127 & 3.250 & 0.012 & 0.001 & 2.139 & 0.016 \\
\hline \multirow[t]{4}{*}{$92 \mathrm{Z} 0560 \mathrm{~F}$} & TTC-5 (6) & “ & 3 & 0.000 & 10.009 & 85.715 & 3.405 & 0.049 & 0.002 & 2.131 & 0.017 \\
\hline & & & & & & & & & Weighted Mean & 2.139 & 0.017 \\
\hline & & & & & & & & & $\pm 1 \mathrm{SEM}$ & 0.006 & \\
\hline & & & & & & & & & MSWD & 0.444 & \\
\hline
\end{tabular}


Appendix 1-Continued

Pit 4 and vicinity

\begin{tabular}{|c|c|c|c|c|c|c|c|c|c|c|c|}
\hline \multicolumn{12}{|c|}{ Tuffs of Blind Spring Valley, TTC-4 } \\
\hline $\begin{array}{l}\text { Irradiation No.: } \\
\text { Experiment No. }\end{array}$ & $\begin{array}{l}\text { CIV-A-6 } \\
\text { Sample }\end{array}$ & $\begin{array}{c}\mathrm{J}=0.000406 \\
\text { Material }\end{array}$ & No. of grains & ${ }^{40} \mathrm{Ar} *(\mathrm{~mol})$ & $\mathrm{K} / \mathrm{Ca}$ & ${ }^{40} \mathrm{Ar} *(\%)$ & ${ }^{40} \mathrm{Ar} /{ }^{39} \mathrm{Ar}$ & ${ }^{37} \mathrm{Ar} /{ }^{39} \mathrm{Ar}$ & ${ }^{36} \mathrm{Ar} /{ }^{39} \mathrm{Ar}$ & Age & \pm 1 s.d. \\
\hline $92 \mathrm{Z} 0559 \mathrm{C}$ & TTC-4 (1) & sanidine & 3 & 0.000 & 9.818 & 80.750 & 3.616 & 0.050 & 0.002 & 2.137 & 0.018 \\
\hline 92Z0559D & TTC-4 (2) & “ & 3 & 0.000 & 54.460 & 84.597 & 3.472 & 0.009 & 0.002 & 2.150 & 0.017 \\
\hline $92 Z 0559 \mathrm{E}$ & TTC-4 (3) & “ & 3 & 0.000 & 38.013 & 83.754 & 3.491 & 0.013 & 0.002 & 2.140 & 0.016 \\
\hline $92 \mathrm{Z} 0559 \mathrm{~F}$ & TTC-4 (4) & “ & 3 & 0.000 & 50.147 & 89.585 & 3.281 & 0.001 & 0.001 & 2.152 & 0.015 \\
\hline 92Z0559G & TTC-4 (5) & “ & 3 & 0.000 & 30.127 & 86.502 & 3.383 & 0.016 & 0.002 & 2.142 & 0.016 \\
\hline $92 \mathrm{Z0559H}$ & TTC-4 (6) & “ & 3 & 0.000 & 33.239 & 88.875 & 3.289 & 0.015 & 0.001 & 2.140 & 0.017 \\
\hline $\begin{array}{l}\text { Irradiation No.: } \\
\text { Experiment No. }\end{array}$ & $\begin{array}{l}\text { CIV-A-34 } \\
\text { Sample }\end{array}$ & $\begin{array}{c}\mathrm{J}=0.0003655 \\
\text { Material }\end{array}$ & No. of grains & ${ }^{40} \mathrm{Ar}^{*}(\mathrm{~mol})$ & $\mathrm{K} / \mathrm{Ca}$ & ${ }^{40} \operatorname{Ar}^{*}(\%)$ & ${ }^{40} \mathrm{Ar} /{ }^{39} \mathrm{Ar}$ & ${ }^{37} \mathrm{Ar} /{ }^{39} \mathrm{Ar}$ & ${ }^{36} \mathrm{Ar} /{ }^{39} \mathrm{Ar}$ & Age & \pm 1 s.d. \\
\hline $92 Z 0586 \mathrm{~A}$ & TTC-4 (7) & Sanidine & $(1.634 \mathrm{mg})$ & 0.000 & 29.957 & 86.798 & 3.706 & 0.016 & 0.002 & 2.120 & 0.015 \\
\hline $92 \mathrm{Z} 0586 \mathrm{C}$ & TTC-4 (8) & “ & $(1.993 \mathrm{mg})$ & 0.000 & 25.660 & 93.603 & 3.460 & 0.019 & 0.001 & 2.134 & 0.014 \\
\hline 92Z0586D & TTC-4 (9) & “ & $(2.819 \mathrm{mg})$ & 0.002 & 41.117 & 95.049 & 3.425 & 0.012 & 0.001 & 2.145 & 0.014 \\
\hline & & & & & & & & & Weighted Mean & 2.140 & 0.016 \\
\hline & & & & & & & & & $\pm 1 \mathrm{SEM}$ & 0.005 & \\
\hline & & & & & & & & & MSWD & 0.039 & \\
\hline \multicolumn{12}{|c|}{ Tuffs of Blind Spring Valley, TTC-15 } \\
\hline Irradiation No.: & CIV-A-11 & $\mathrm{J}=0.000400$ & & & & & & & & & \\
\hline Experiment No. & Sample & Material & No. of grains & ${ }^{40} \mathrm{Ar} *(\mathrm{~mol})$ & $\mathrm{K} / \mathrm{Ca}$ & ${ }^{40} \mathrm{Ar} *(\%)$ & ${ }^{40} \mathrm{Ar} /{ }^{39} \mathrm{Ar}$ & ${ }^{37} \mathrm{Ar} /{ }^{39} \mathrm{Ar}$ & ${ }^{36} \mathrm{Ar} /{ }^{39} \mathrm{Ar}$ & Age & \pm 1 s.d. \\
\hline $92 \mathrm{Z} 0564 \mathrm{~A}$ & TTC-15 (1) & qtz-san-plag? & 4 & 0.000 & 5.089 & 12.818 & 16.643 & 0.096 & 0.049 & $1.5388 *$ & 0.030 \\
\hline $92 \mathrm{Z} 0561 \mathrm{~A}$ & TTC-15 (2) & sanidine & 5 or 6 & 0.000 & 37.261 & 88.916 & 3.334 & 0.013 & 0.001 & 2.137 & 0.017 \\
\hline 92Z0561B & TTC-15 (3) & “ & 5 or 6 & 0.000 & 36.843 & 91.569 & 3.257 & 0.013 & 0.001 & 2.150 & 0.017 \\
\hline $92 Z 0561 C$ & TTC-15 (4) & “ & 5 or 6 & 0.000 & 12.247 & 91.098 & 3.303 & 0.040 & 0.000 & 2.169 & 0.021 \\
\hline 92Z0561D & TTC-15 (5) & “ & 5 or 6 & 0.000 & 23.481 & 81.732 & 3.669 & 0.021 & 0.002 & 2.163 & 0.017 \\
\hline $92 Z 0561 \mathrm{E}$ & TTC-15 (6) & “ & 5 or 6 & 0.000 & 17.314 & 92.591 & 3.206 & 0.028 & 0.001 & 2.141 & 0.018 \\
\hline \multirow[t]{4}{*}{$92 \mathrm{Z} 0561 \mathrm{~F}$} & TTC-15 (7) & “ & 5 or 6 & 0.000 & 26.660 & 84.296 & 3.565 & 0.018 & 0.002 & 2.167 & 0.021 \\
\hline & & & & & & & & & Weighted Mean & 2.153 & 0.018 \\
\hline & & & & & & & & & \pm 1 SEM & 0.007 & \\
\hline & & & & & & & & & MSWD & 0.500 & \\
\hline
\end{tabular}


Appendix 1-Continued

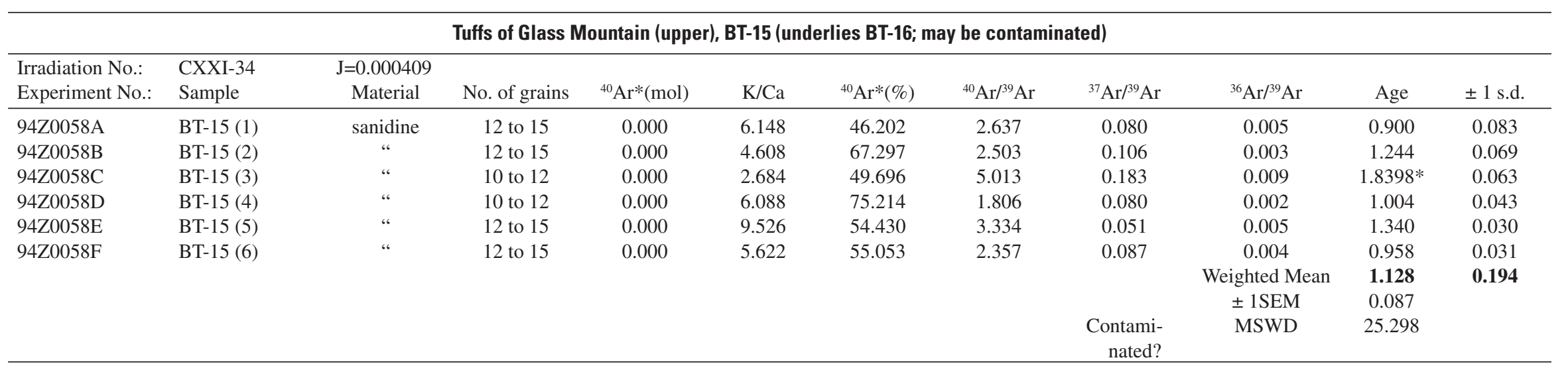

Willow Wash Locality

Tuffs of Benton Hot Springs, FLV-23-WW (see TTC-26B, above)

\begin{tabular}{|c|c|c|c|c|c|c|c|c|c|c|c|}
\hline $\begin{array}{l}\text { Irradiation No.: } \\
\text { Experiment No.: }\end{array}$ & $\begin{array}{l}\text { CXXI-30 } \\
\text { Sample }\end{array}$ & $\begin{array}{c}\mathrm{J}=0.000413 \\
\text { Material }\end{array}$ & No. of grains & ${ }^{40} \mathrm{Ar}^{*}(\mathrm{~mol})$ & $\mathrm{K} / \mathrm{Ca}$ & ${ }^{40} \mathrm{Ar}^{*}(\%)$ & ${ }^{40} \mathrm{Ar} /{ }^{39} \mathrm{Ar}$ & ${ }^{37} \mathrm{Ar} /{ }^{39} \mathrm{Ar}$ & ${ }^{36} \mathrm{Ar} /{ }^{39} \mathrm{Ar}$ & Age & \pm 1 s.d. \\
\hline $94 Z 0055 \mathrm{~A}$ & $\begin{array}{l}\text { FLV-23-WW } \\
\text { (1) }\end{array}$ & plagioclase & 7 & 0.000 & 0.274 & 85.892 & 4.390 & 1.783 & 0.003 & 2.809 & 0.152 \\
\hline 94Z0055B & $\begin{array}{l}\text { FLV-23-WW } \\
\text { (2) }\end{array}$ & “ & 6 & 0.000 & 0.323 & 86.905 & 4.438 & 1.513 & 0.002 & 2.873 & 0.099 \\
\hline 94Z0055C & $\begin{array}{l}\text { FLV-23-WW } \\
\text { (3) }\end{array}$ & “ & 10 & 0.000 & 0.299 & 85.971 & 4.567 & 1.636 & 0.003 & 2.925 & 0.064 \\
\hline 94Z0055D & $\begin{array}{l}\text { FLV-23-WW } \\
\text { (4) }\end{array}$ & “ & 7 & 0.000 & 0.472 & 86.738 & 4.373 & 1.036 & 0.002 & 2.824 & 0.068 \\
\hline 94Z0055E & $\begin{array}{l}\text { FLV-23-WW } \\
\text { (5) }\end{array}$ & “ & 4 & 0.000 & 0.419 & 73.354 & 5.246 & 1.168 & 0.005 & 2.865 & 0.097 \\
\hline \multirow[t]{4}{*}{$94 \mathrm{Z} 0055 \mathrm{~F}$} & $\begin{array}{l}\text { FLV-23-WW } \\
\text { (6) }\end{array}$ & “ & 6 & 0.000 & 0.372 & 97.164 & 4.200 & 1.315 & 0.001 & 3.039 & 0.087 \\
\hline & & & & & & & & & Weighted Mean & 2.894 & 0.082 \\
\hline & & & & & & & & & $\pm 1 \mathrm{SEM}$ & 0.033 & \\
\hline & & & & & & & & & MSWD & 0.944 & \\
\hline
\end{tabular}




\begin{tabular}{|c|c|c|c|c|c|c|c|c|c|c|c|}
\hline $\begin{array}{l}\text { Irradiation No.: } \\
\text { Experiment No.: }\end{array}$ & $\begin{array}{l}\text { CIV-A-4 } \\
\text { Sample }\end{array}$ & $\begin{array}{c}\mathrm{J}=0.000408 \\
\text { Material }\end{array}$ & No. of grains & ${ }^{40} \mathrm{Ar}^{*}(\mathrm{~mol})$ & $\mathrm{K} / \mathrm{Ca}$ & ${ }^{40} \operatorname{Ar} *(\%)$ & ${ }^{40} \mathrm{Ar} /{ }^{39} \mathrm{Ar}$ & ${ }^{37} \mathrm{Ar} /{ }^{39} \mathrm{Ar}$ & ${ }^{36} \mathrm{Ar} /{ }^{39} \mathrm{Ar}$ & Age & \pm 1 s.d. \\
\hline $92 \mathrm{Z} 0547 \mathrm{~F}$ & $68-\mathrm{O}-40(1)$ & sanidine & 1 & 0.000 & 40.914 & 77.725 & 3.572 & 0.012 & 0.003 & 2.042 & 0.019 \\
\hline 92Z0547E & $68-\mathrm{O}-40$ (2) & “ & 1 & 0.000 & 29.841 & 76.800 & 3.645 & 0.016 & 0.003 & 2.059 & 0.054 \\
\hline 92Z0547D & $68-\mathrm{O}-40(3)$ & “ & 1 & 0.000 & 26.938 & 87.734 & 3.191 & 0.018 & 0.001 & 2.059 & 0.021 \\
\hline 92Z0547C & $68-\mathrm{O}-40(4)$ & “ & 1 & 0.000 & 26.590 & 88.468 & 3.235 & 0.018 & 0.001 & 2.105 & 0.021 \\
\hline $92 \mathrm{Z} 0547 \mathrm{~B}$ & $68-\mathrm{O}-40(4)$ & “ & 1 & 0.000 & 48.286 & 82.541 & 3.301 & 0.010 & 0.002 & 2.004 & 0.024 \\
\hline 92Z0547A & $68-\mathrm{O}-40(6)$ & “ & 1 & 0.000 & 26.327 & 90.047 & 3.110 & 0.019 & 0.001 & 2.060 & 0.083 \\
\hline $92 \mathrm{Z} 0547 \mathrm{~F}$ & $68-0-40(7)$ & “ & 1 & 0.000 & 29.286 & 77.748 & 3.591 & 0.017 & 0.003 & 2.049 & 0.020 \\
\hline $\begin{array}{l}\text { Irradiation No.: } \\
\text { Experiment No. }\end{array}$ & $\begin{array}{l}\text { CIV-A-4 } \\
\text { Sample }\end{array}$ & $\begin{array}{c}\mathrm{J}=0.000407 \\
\text { Material }\end{array}$ & No. of grains & ${ }^{40} \mathrm{Ar} *(\mathrm{~mol})$ & $\mathrm{K} / \mathrm{Ca}$ & ${ }^{40} \mathrm{Ar}^{*}(\%)$ & ${ }^{40} \mathrm{Ar} /{ }^{39} \mathrm{Ar}$ & ${ }^{37} \mathrm{Ar} /{ }^{39} \mathrm{Ar}$ & ${ }^{36} \mathrm{Ar} /{ }^{39} \mathrm{Ar}$ & Age & \pm 1 s.d. \\
\hline 92Z0547E & $68-\mathrm{O}-40(8)$ & “ & 1 & 0.000 & 15.947 & 75.974 & 3.665 & 0.031 & 0.003 & 2.043 & 0.050 \\
\hline 92Z0547D & $68-\mathrm{O}-40(9)$ & “ & 1 & 0.000 & 21.060 & 87.445 & 3.208 & 0.023 & 0.001 & 2.058 & 0.021 \\
\hline 92Z0547C & $68-\mathrm{O}-40(10)$ & “ & 1 & 0.000 & 20.589 & 88.140 & 3.252 & 0.024 & 0.001 & 2.103 & 0.022 \\
\hline 92Z0547B & $68-\mathrm{O}-40(11)$ & “ & 1 & 0.000 & 29.345 & 82.242 & 3.319 & 0.017 & 0.002 & 2.003 & 0.025 \\
\hline 92Z0547A & $68-\mathrm{O}-40(12)$ & “ & 1 & 0.000 & 21.222 & 89.757 & 3.127 & 0.023 & 0.001 & 2.060 & 0.019 \\
\hline $\begin{array}{l}\text { Irradiation No.: } \\
\text { Experiment No. }\end{array}$ & $\begin{array}{l}\text { CIV-A-31 } \\
\text { Sample }\end{array}$ & $\begin{array}{c}\mathrm{J}=0.000371 \\
\text { Material }\end{array}$ & No. of grains & ${ }^{40} \mathrm{Ar}^{*}(\mathrm{~mol})$ & $\mathrm{K} / \mathrm{Ca}$ & ${ }^{40} \mathrm{Ar} *(\%)$ & ${ }^{40} \mathrm{Ar} /{ }^{39} \mathrm{Ar}$ & ${ }^{37} \mathrm{Ar} /{ }^{39} \mathrm{Ar}$ & ${ }^{36} \mathrm{Ar} /{ }^{39} \mathrm{Ar}$ & Age & \pm 1 s.d. \\
\hline $92 \mathrm{Z} 0546 \mathrm{E}$ & $68-\mathrm{O}-40(13)$ & sanidine & 1 & 0.000 & 18.329 & 80.895 & 3.823 & 0.027 & 0.002 & 2.057 & 0.034 \\
\hline $92 \mathrm{Z} 0546 \mathrm{~F}$ & $68-\mathrm{O}-40(14)$ & “ & 1 & 0.000 & 24.531 & 81.116 & 3.805 & 0.020 & 0.002 & 2.064 & 0.034 \\
\hline $\begin{array}{l}\text { Irradiation No.: } \\
\text { Experiment No. }\end{array}$ & $\begin{array}{l}\text { CIV-A-31 } \\
\text { Sample }\end{array}$ & $\begin{array}{c}\mathrm{J}=0.000369 \\
\text { Material }\end{array}$ & No. of grains & ${ }^{40} \mathrm{Ar} *(\mathrm{~mol})$ & $\mathrm{K} / \mathrm{Ca}$ & ${ }^{40} \mathrm{Ar} *(\%)$ & ${ }^{40} \mathrm{Ar} /{ }^{39} \mathrm{Ar}$ & ${ }^{37} \mathrm{Ar} /{ }^{39} \mathrm{Ar}$ & ${ }^{36} \mathrm{Ar} /{ }^{39} \mathrm{Ar}$ & Age & \pm 1 s.d. \\
\hline 92Z0544B & $68-O-40(15)$ & sanidine & 1 & 0.000 & 41.949 & 92.625 & 3.373 & 0.012 & 0.001 & 2.078 & 0.021 \\
\hline 92Z0546B & $68-\mathrm{O}-40(16)$ & “ & 1 & 0.000 & 17.151 & 93.340 & 3.296 & 0.029 & 0.001 & 2.046 & 0.019 \\
\hline $92 \mathrm{Z} 0546 \mathrm{C}$ & $68-\mathrm{O}-40(17)$ & “ & 1 & 0.000 & 35.930 & 94.729 & 3.363 & 0.014 & 0.001 & 2.119 & 0.022 \\
\hline 92Z0546D & $68-\mathrm{O}-40(18)$ & “ & 1 & 0.000 & 15.436 & 89.246 & 3.432 & 0.032 & 0.001 & 2.038 & 0.025 \\
\hline \multirow[t]{4}{*}{$92 Z 0544 \mathrm{~A}$} & $68-0-40(19)$ & “ & 1 & 0.000 & 34.855 & 87.526 & 3.591 & 0.014 & 0.002 & 2.091 & 0.018 \\
\hline & & & & & & & & Weighted mean & $\mathrm{N}=19$ & 2.063 & 0.031 \\
\hline & & & & & & & & & $\pm 1 \mathrm{SEM}$ & 0.007 & \\
\hline & & & & & & & & & MSWD & 1.721 & \\
\hline
\end{tabular}


Appendix 2 Analytical data for conventinal K-Ar analysis of obsidian clasts from the lower tephra layers of Glass Mountain at the Cowan Pumice Mine, Blind Spring Valley, Calif. John Nakata, analyst, United States Geological Survey, Menlo Park, 1987.

\begin{tabular}{|c|c|c|c|c|c|c|c|c|c|c|}
\hline Sample No. & Latitude $\mathrm{N}$ & Longitude W & Quadrangle & Rock Type & $\begin{array}{c}\text { Material } \\
\text { Dated }\end{array}$ & Ave. $\mathrm{K}_{2} \mathrm{O}$ & ${ }^{40} \mathrm{Ar} / \Sigma^{40} \mathrm{Ar}$ & ${ }^{40} \mathrm{Ar} * \mathrm{~mol} / \mathrm{g}$ & Age (Ma) & Anal. Error \\
\hline TTC-24-OB(1) & 374700 & 1183200 & Glass Mt. $15^{\prime}$ & Obsidian & glass & 4.75 & 14 & 0.000 & 1.98 & 0.025 \\
\hline \multirow[t]{4}{*}{ TTC-24-OB(2) } & 374700 & 1183200 & Glass Mt. 15' & Obsidian & glass & 4.70 & 25 & 0.000 & 1.79 & 0.025 \\
\hline & & & & & & & & Weighted Mean & 1.86 & 0.120 \\
\hline & & & & & & & & Weighted SEM & 0.085 & \\
\hline & & & & & & & & MSWD & 4.230 & \\
\hline
\end{tabular}


Appendix 3 Analytical data for laser-fusion ${ }^{40} \mathrm{Ar} /{ }^{39} \mathrm{Ar}$ analysis of samples that were contaminated with detrital material.

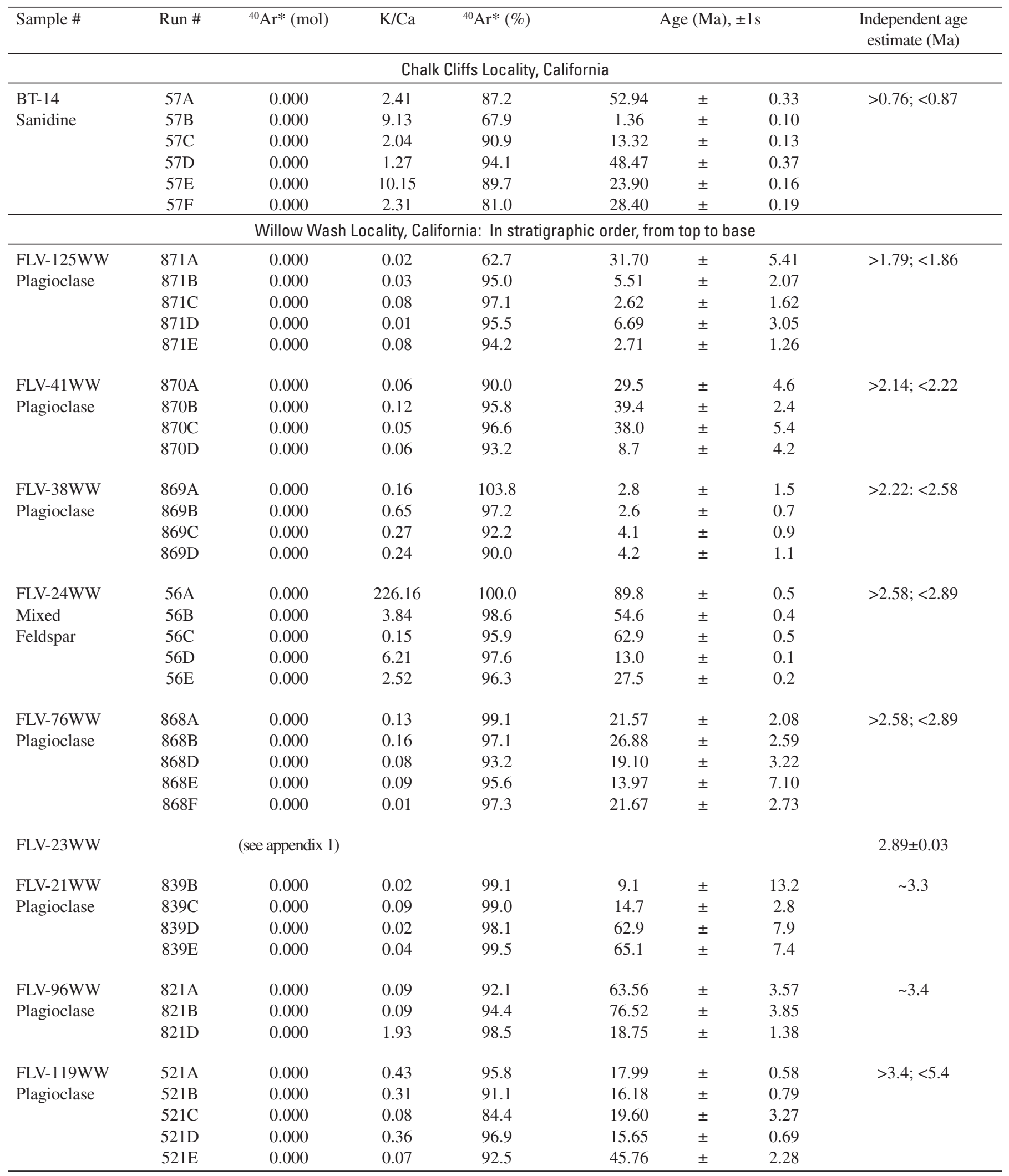


Appendix 3-Continued

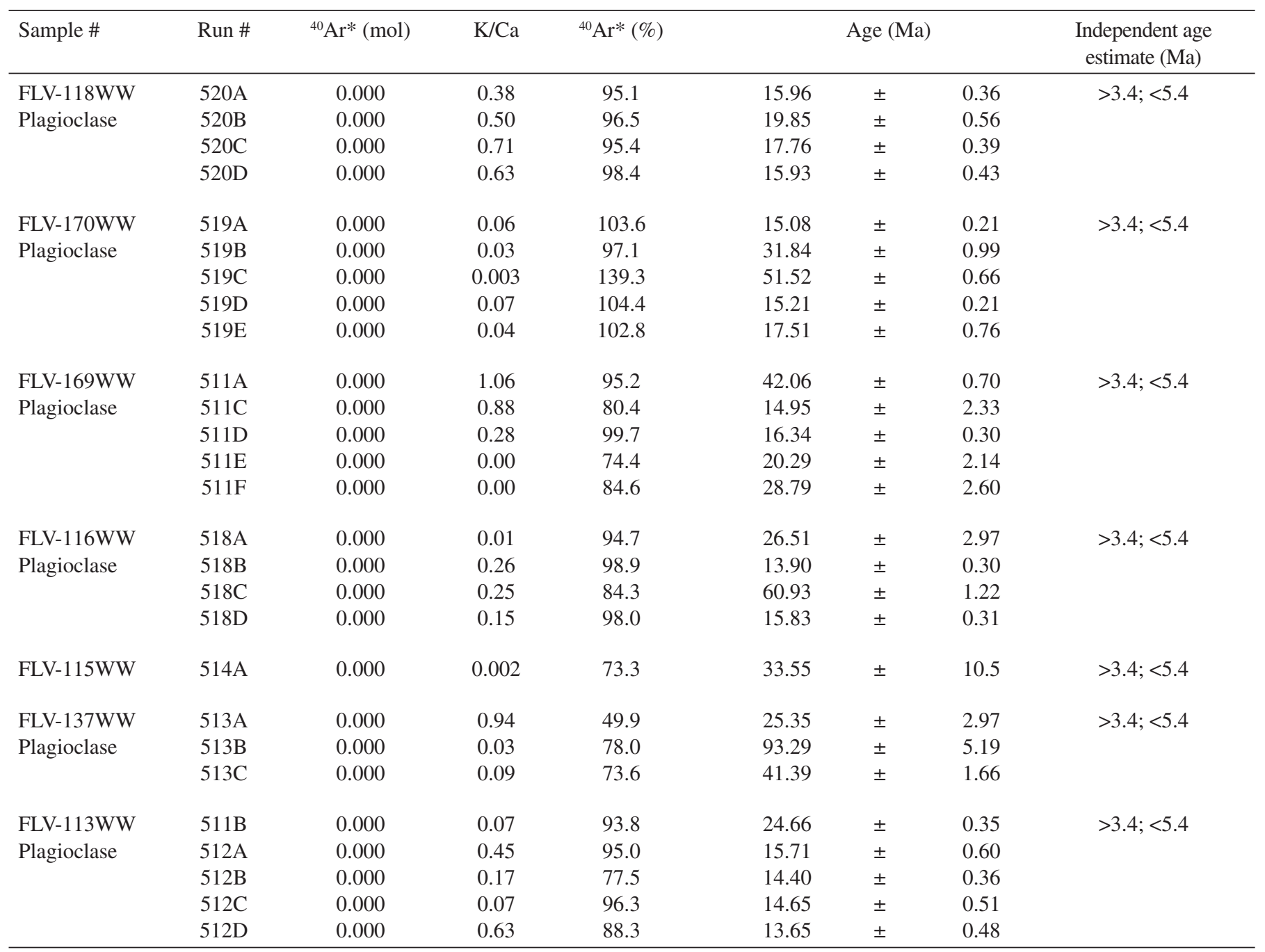

